\title{
Hydrologic investigation of three constructed mitigation wetlands and one natural wetland in West Virginia
}

\author{
Scott A. Copen \\ West Virginia University
}

Follow this and additional works at: https://researchrepository.wvu.edu/etd

\section{Recommended Citation}

Copen, Scott A., "Hydrologic investigation of three constructed mitigation wetlands and one natural wetland in West Virginia" (2004). Graduate Theses, Dissertations, and Problem Reports. 1483.

https://researchrepository.wvu.edu/etd/1483

This Thesis is protected by copyright and/or related rights. It has been brought to you by the The Research Repository @ WVU with permission from the rights-holder(s). You are free to use this Thesis in any way that is permitted by the copyright and related rights legislation that applies to your use. For other uses you must obtain permission from the rights-holder(s) directly, unless additional rights are indicated by a Creative Commons license in the record and/ or on the work itself. This Thesis has been accepted for inclusion in WVU Graduate Theses, Dissertations, and Problem Reports collection by an authorized administrator of The Research Repository @ WVU. For more information, please contact researchrepository@mail.wvu.edu. 
Hydrologic Investigation of Three Constructed Mitigation Wetlands and One Natural Wetland in West Virginia

\title{
Scott A. Copen
}

\author{
Thesis submitted to the \\ College of Engineering and Mineral Resources \\ at West Virginia University \\ in partial fulfillment of the requirements \\ for the degree of
}

\author{
Master of Science \\ In \\ Civil Engineering \\ Donald D. Gray, Ph.D., P.E., Chairman \\ Darrell R. Dean, Jr., Ph.D. P.S. \\ Robert N. Eli, Ph. D., P.E. \\ Ronald H. Fortney, Ph.D. \\ Department of Civil and Environmental Engineering
}

Morgantown, West Virginia

2004

Keywords: Wetland Mitigation, Hydrologic Investigation, Groundwater Modeling Copyright 2004 Scott A. Copen 


\begin{abstract}
Hydrologic Investigation of Three Constructed Mitigation Wetlands and One Natural Wetland in West Virginia
\end{abstract}

Scott A. Copen

The goal of this study was to increase the probability of success for future mitigation wetland projects by performing a hydrologic investigation at three constructed mitigation wetland sites and one natural reference wetland site. In addition, a numerical groundwater model was developed for a portion of one of the constructed mitigation wetlands.

Hydrologic, meteorologic, topographic, and geotechnical data were collected at three constructed mitigation wetlands and one reference natural wetland. Hydrologic data were collected using monitoring wells, piezometers, automated water level recorders, and a water level meter. Meteorologic data were obtained from the National Oceanic and Atmospheric Administration's weather station in Elkins, West Virginia. Topographic data were collected using traditional surveying techniques. Geotechnical data were inferred from bag samples obtained during hydrologic monitoring device installation, from Shelby tubes, and from in-situ slug tests. These data were used to compare hydrologic conditions at the constructed mitigation wetlands to the natural reference wetland. In addition, a detailed numerical groundwater model was developed for one of the mitigation sites.

Persistent sources of groundwater were determined to be the most important factor favoring the successful development of the mitigation wetlands. Areas at the mitigation sites that were not developing satisfactorily were found to have the deepest and most variable groundwater levels. It is recommended that future wetland mitigation sites be selected where groundwater can be used as the primary source of water. 


\section{ACKNOWLEGDEMENTS}

I would first like to thank the West Virginia Division of Highways (WVDOH) for providing the necessary funding for this project. I would also like to say that the views expressed in this document represent the thoughts of the authors and not those of the WVDOH.

The help my committee has provided over the time it has taken for me to complete my thesis is invaluable. The knowledge I have gained through the teachings of Dr. Gray has guided and will continue to guide my professional career in the area of water resources. His teachings have left a lasting impression on me that will never be forgotten. Dr. Fortney has provided me with more knowledge and insight about myself and my career than he will ever know. He has acted as a mentor for me in my academic learning and my personal development. His level of unselfishness and dedication to his work has and will continue to inspire me for the longevity of my career.

Without the hard worked performed by John Cross, John Dubowski, John Gillilan, and Brad Messenger, I would not have been able to complete this project. I would like to thank them for helping me install the equipment in the field. I would particularly like to thank Brad Messenger for his help. He has helped me with the completion of this work more that anyone knows. In addition, he has become a lasting friend.

I would like to thank Conrad Baston and Jon Lester for their friendship and guidance.

I would like to thank my family. I know that I will never be able to explain why this process took so much time, but I do appreciate all of the support they have shown me. I want to personally thank my father (Allen), stepmother (Vicki), little sister (Jessica), mother (Darlene), stepfather (Tim), big sister (Missy), grandfather (Gene), and grandmother (Libby) who will always be missed and loved. Their patience, support, and love over the years have meant more to me than they could ever imagine.

Lastly, I would like to thank my wonderful wife Pam. Her love and support during this time has been imaginable. I am truly sorry for all of the time I was not at home. 


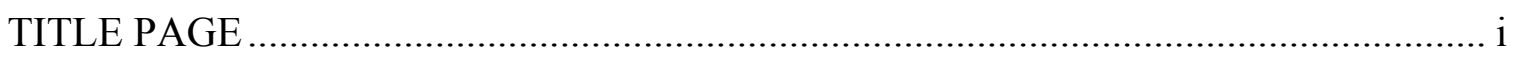

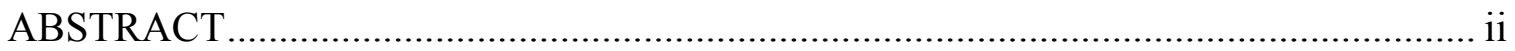

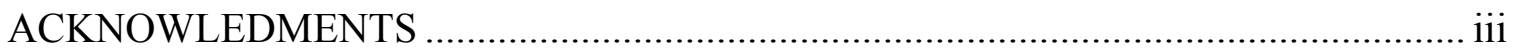

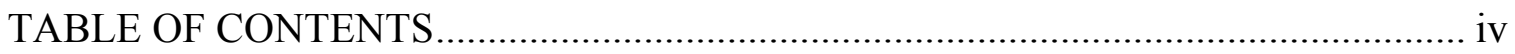

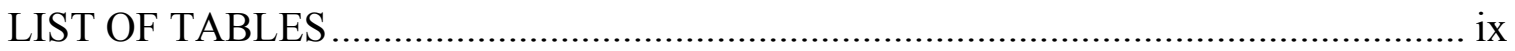

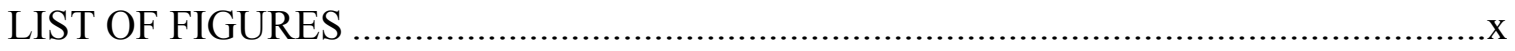

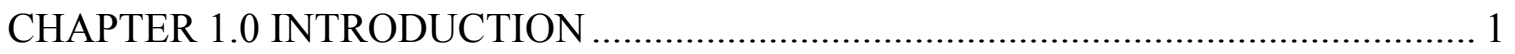

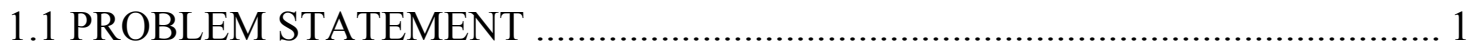

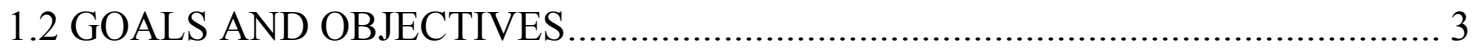

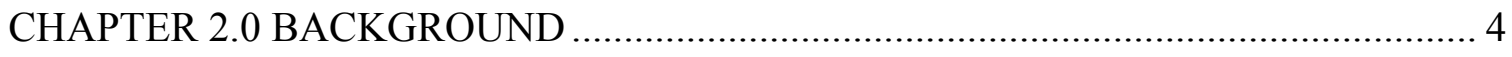

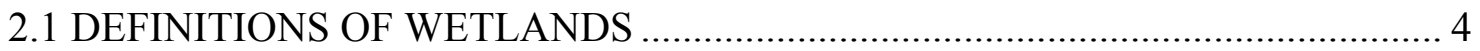

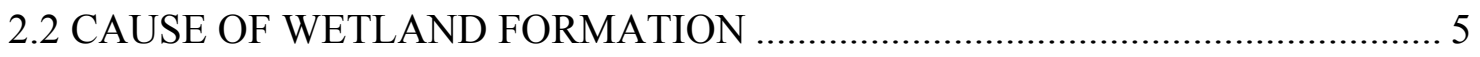

2.2.1 Broad alluvial filled valleys .................................................................... 5

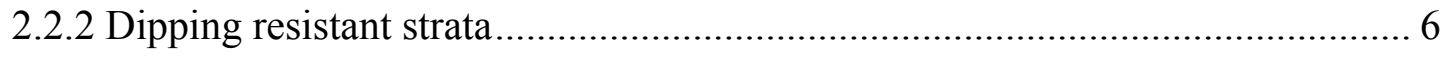

2.2.3 Dissected plateau with flat-lying strata ......................................................... 7

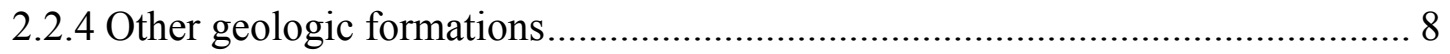

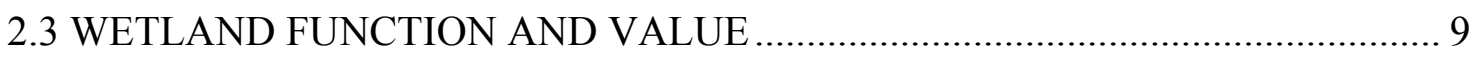

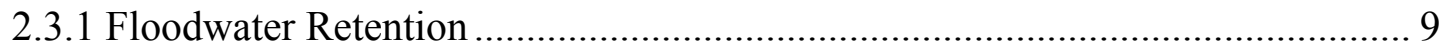

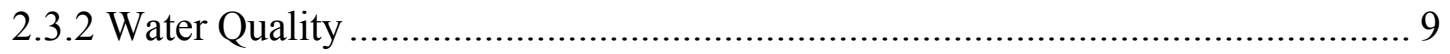

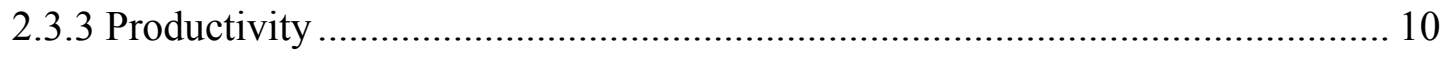

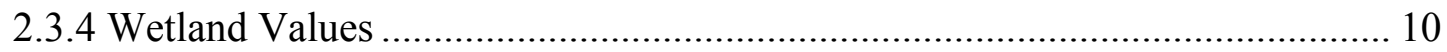




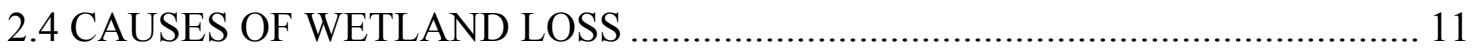

2.5 REASONS FOR WETLAND MITIGATION _.................................................. 11

2.5.1 Section 404 of the Clean Water Act of 1972 .................................................. 12

2.5.2 Executive Order 11990......................................................................... 12

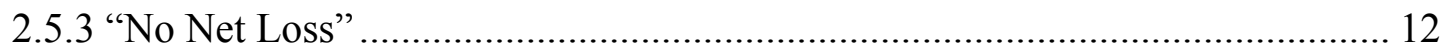

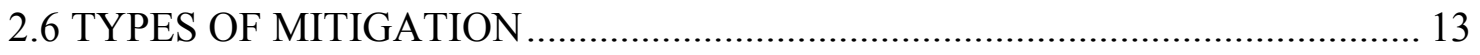

2.7 MITIGATION WETLAND CONSTRUCTION METHODS ................................ 13

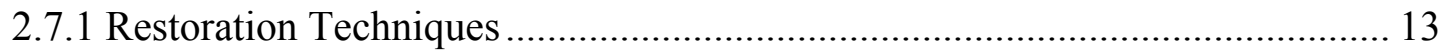

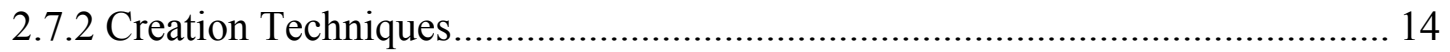

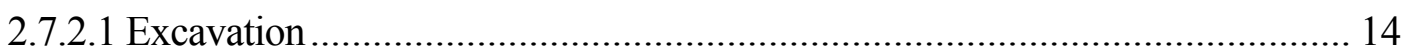

2.7.2.2 Excavation and Installation of Low Hydraulic Conductivity Liner ................. 15

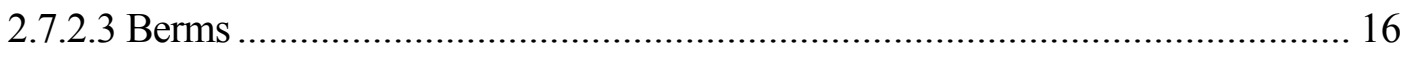

2.8 EFFECTIVENESS OF WETLAND MITIGATION CONSTRUCTION.............. 177

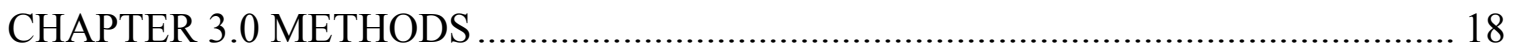

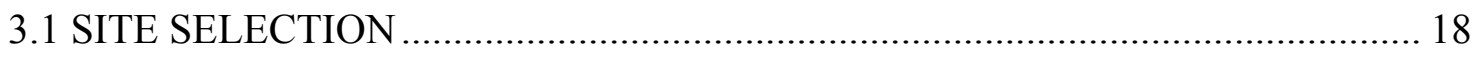

3.1.1 Leading Creek ……………………........................................................ 19

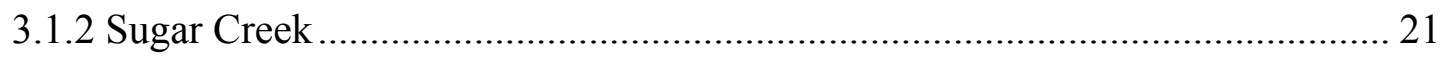

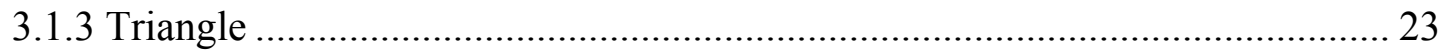

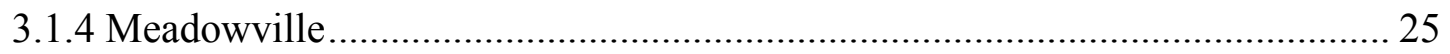

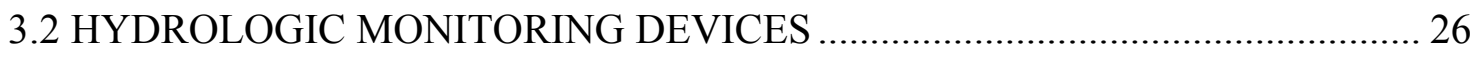

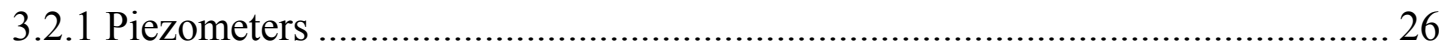

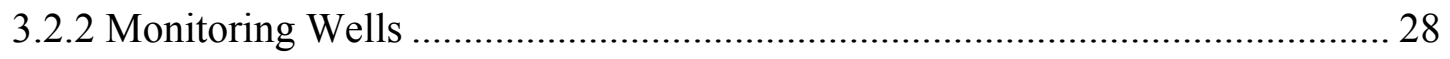




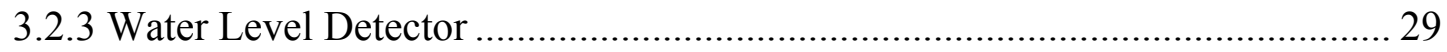

3.2.4 Automated Water Level Recorders ............................................................... 30

3.2.5 Monitoring Device Location Plan .................................................................... 31

3.2.6 Hydrologic Data Collection ......................................................................... 35

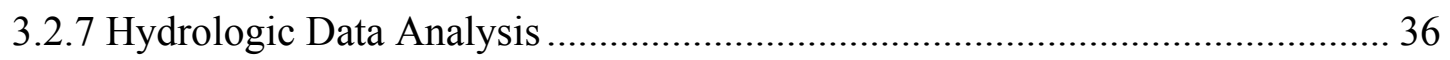

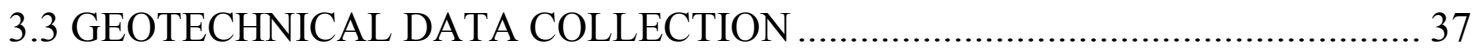

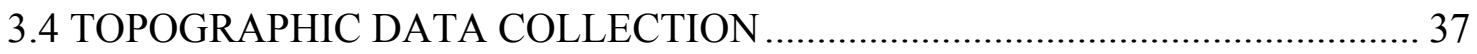

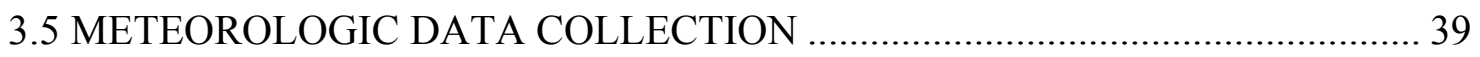

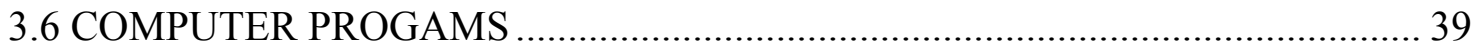

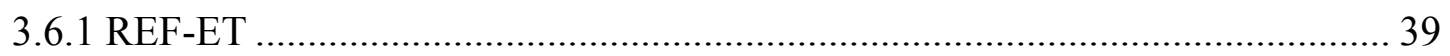

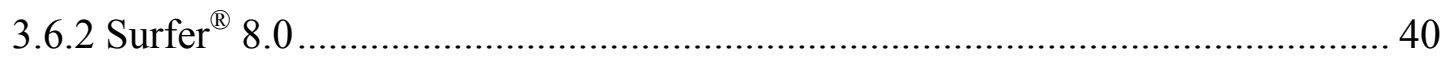

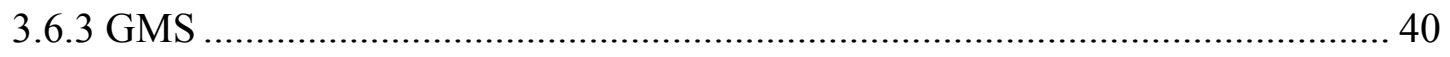

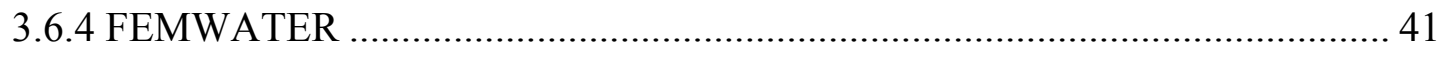

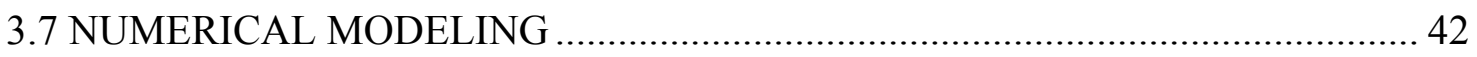

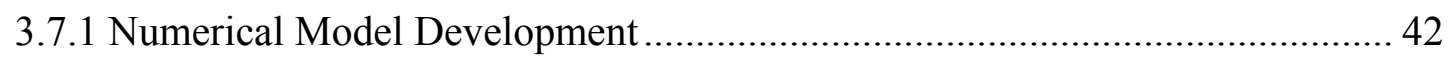

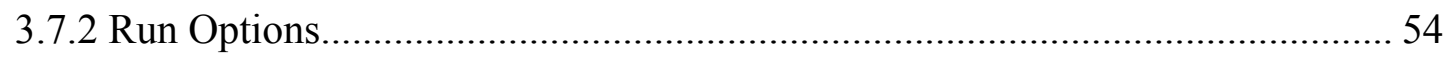

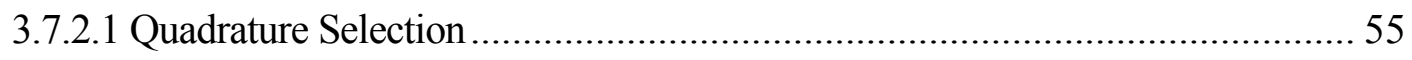

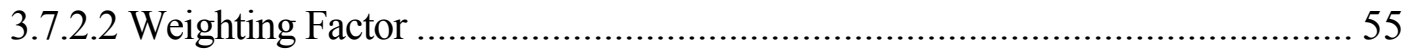

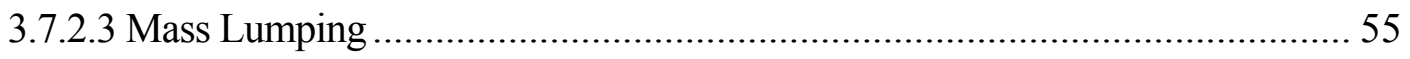

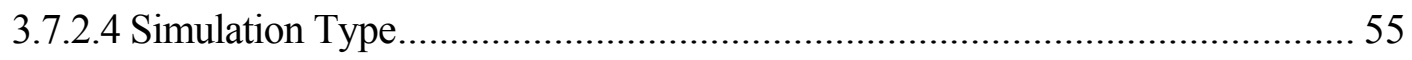

3.7.2.5 Relaxation Parameter for Nonlinear Flow (OMEF)...................................... 56

3.7.2.6 Relaxation Parameter for Linearized Flow (OMIF) ....................................... 56 


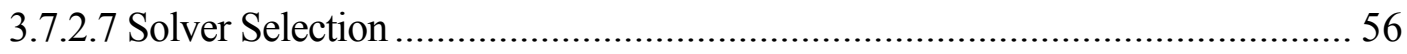

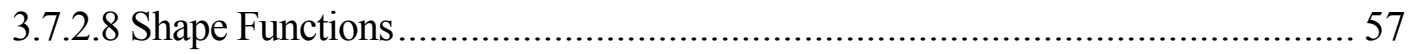

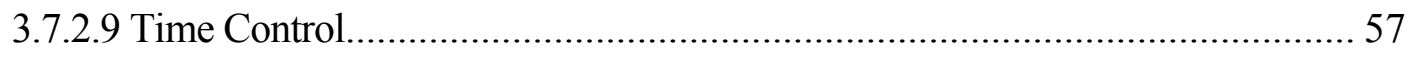

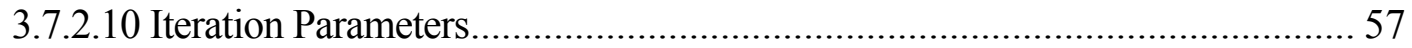

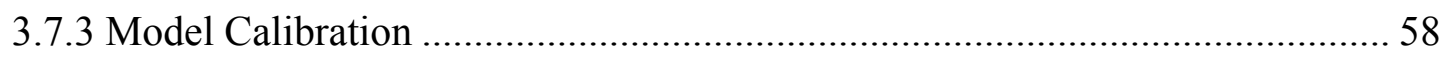

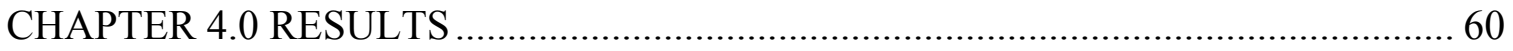

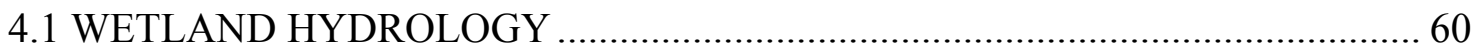

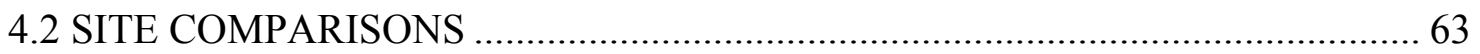

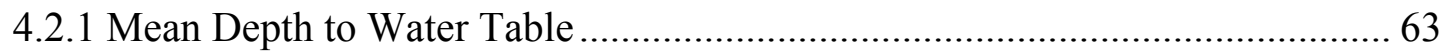

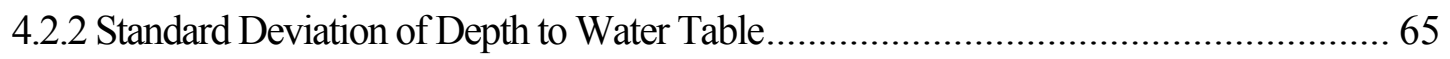

4.3 LEADING CREEK HYDROLOGIC MODELING............................................. 66

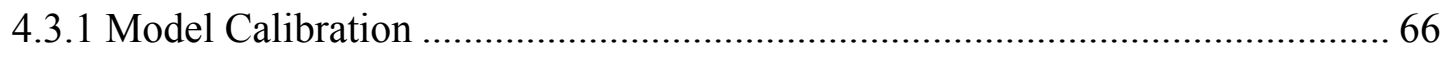

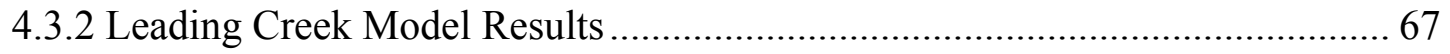

CHAPTER 5.0 DISCUSSION AND RECCOMENDATIONS ...................................... 73

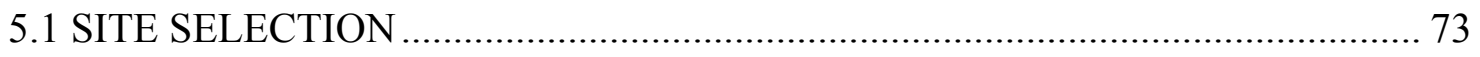

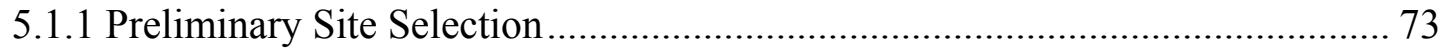

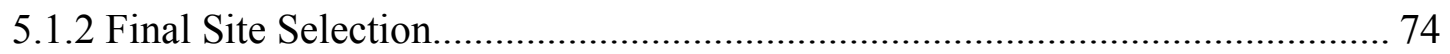

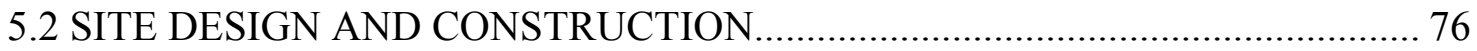

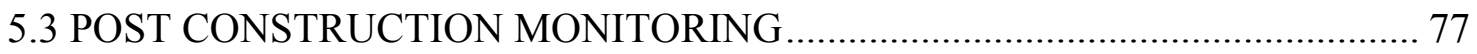

CHAPTER 6.0 SUMMARY AND CONCLUSIONS ……………….......................... 78

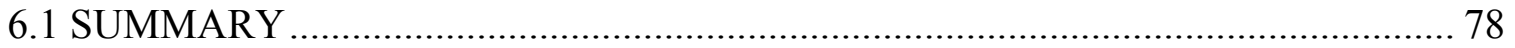

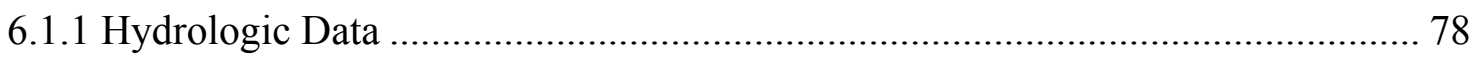




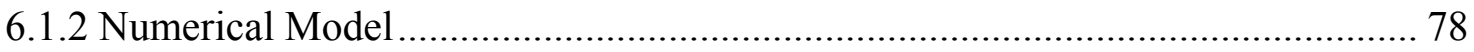

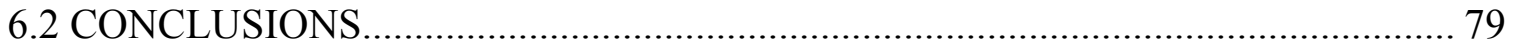

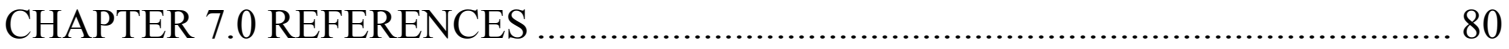

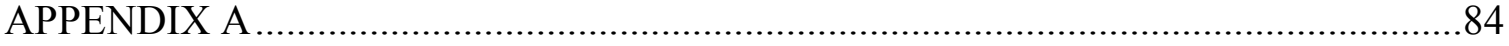

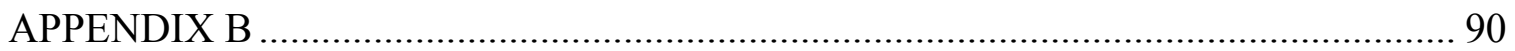




\section{LIST OF TABLES}

TABLE

PAGE

Table 3.4.1 Table of control station coordinates used for the topographic surveying of the Leading site ...............................................................38

Table 3.7.1.1 Values of simulated saturated hydraulic conductivities ......................48

Table 3.7.1.2. $\quad$ Tabulated input parameters used to generate the unsaturated moisture content, relative conductivity, and water capacity for each of the simulated materials

Table 4.3.1.1 Daily RMS differences between the hydrologic model head values simulated for the Leading Creek site and observed field values. 
Figure 2.2.1.1 Cross-section of broad alluvial filled valley. (From Diehl and Behling 1982)

Figure 2.2.2.1 Cross-section of dipping resistant strata. (From Diehl and Behling 1982).

Figure 2.2.3.1 Cross-section of dissected plateau with flat-lying strata. (From Diehl and Behling 1982)

Figure 2.7.2.2.1 Typical cross-section of excavation and installation of low hydraulic conductivity liner. (From USACE 2000)

Figure 3.1.1 Regional map of study area showing site locations, county seats, and major highways.

Figure 3.1.1.1 Aerial photograph of the Leading Creek mitigation wetland showing wetland classification and study area. (Aerial photograph provided by Natural Resource Analysis Center at West Virginia University)

Figure 3.1.2.1 Aerial photograph of the Sugar Creek mitigation wetland showing wetland classification and study area. (Aerial photograph provided by Natural Resource Analysis Center at West Virginia University)

Figure 3.1.3.1 Aerial photograph of the Triangle mitigation wetland showing wetland classification and study area. (Aerial photograph provided by Natural Resource Analysis Center at West Virginia University).....

Figure 3.1.4.1 Aerial photograph of the Meadowville reference wetland showing wetland classification and study area. (Aerial photograph downloaded from the West Virginia Department of Environmental Protection)

Figure 3.2.1.1 Schematic drawing of piezometer. …………………........................2

Figure 3.2.2.1 Schematic drawing of monitoring well ................................................29

Figure 3.2.3.1 Schematic drawing of automated water level recorder. .........................31 
Figure 3.2.5.1 Aerial photograph of the Leading Creek mitigation wetland showing monitoring device locations. (Aerial photograph provided by Natural Resources Analysis Center at West Virginia University)

Figure 3.2.5.2 Aerial photograph of the Sugar Creek mitigation wetland showing monitoring device locations. (Aerial photograph provided by Natural Resources Analysis Center at West Virginia University)

Figure 3.2.5.3 Aerial photograph of the Triangle mitigation wetland showing monitoring device locations. (Aerial photograph provided by Natural Resources Analysis Center at West Virginia University)

Figure 3.2.5.4 Aerial photograph of the Meadowville reference wetland showing monitoring device locations. (Aerial photograph downloaded from the West Virginia Department of Environmental Protection)

Figure 3.4.1 Topographic map of the Leading Creek study site showing contour lines and control stations.

Figure 3.7.1.1a Figure showing the initial TIN representing the ground surface at the Leading Creek site.

Figure 3.7.1.1b Figure showing the initial TIN representing the soil interface at the Leading Creek site.

Figure 3.7.1.2a Figure showing the final TIN representing the ground surface at the Leading Creek site.

Figure 3.7.1.2b Figure showing the final TIN representing the soil interface at the Leading Creek site.

Figure 3.7.1.3 3D mesh of the Leading Creek site showing the elements and assigned materials.

Figure 3.7.1.4 Generated curves in the upper layer for water content, relative conductivity, and water capacity in the unsaturated zone using the van Genuchten generator in GMS.

Figure 3.7.1.5 3D mesh of the Leading Creek site showing boundary condition assignments.

Figure 4.1.1 Water level elevations relative to the ground surface at the eastern side of the Leading Creek site 
Figure 4.1.2 Water level elevations relative to the ground surface at the western side of the Leading Creek site

Figure 4.1.3 Water level elevations relative to the ground surface at the Sugar Creek site.

Figure 4.1.4 Water level elevations relative to the ground surface at the Triangle site.

Figure 4.1.5 Water level elevations relative to the ground surface at the Meadowville site

Figure 4.2.1.1 Graph of mean depth to water table for each well at the study sites

Figure 4.2.2.1 Graph of standard deviation to depth of water table for each well at the study sites.

Figure 4.3.2.1 Figure of the Leading Creek hydrologic model showing pressure head at the ground surface on June 7, 2001......

Figure 4.3.2.2 Figure of the Leading Creek hydrologic model showing pressure head at the ground surface on June 8, 2001.

Figure 4.3.2.3 Figure of the Leading Creek hydrologic model showing pressure head at the ground surface on June 11, 2001.

Figure 4.3.2.4 Figure of the Leading Creek hydrologic model showing pressure head at the ground surface on June 15, 2001. 


\section{CHAPTER 1.0 INTRODUCTION}

\subsection{PROBLEM STATEMENT}

The most important and controlling factor in the development of a wetland is the amount of water available through precipitation, surface, and subsurface sources. Hydrophytic plants depend on the presence of this water at or near the ground surface for all or part of the growing season. Hydric soils cannot develop without the anaerobic conditions created by these hydrologic regimes.

Functional assessments of mitigation wetlands are often based on vegetative cover and the presence of early stage redoximorphic features in the near surface soil horizons (National Research Council 2001). Little hydrologic data exists for extended periods after wetland mitigation construction occurs. Therefore, post construction hydrologic data is often inferred from the results of the vegetative surveys and soil properties.

The time frame between construction and final evaluation of constructed wetlands is typically five years. This period does not allow enough time for relatively stable site vegetation or hydric soil conditions to develop (National Research Council 2001). Onsite vegetative surveys after this period often show low plant diversity in which early succession species and/or invasive species dominate (National Research Council 2001). Since excavation is a common practice in wetland construction, the soil zones that are now located near the ground surface may have been historically located several feet below the ground surface. In some cases, these soil zones could show signs of past anaerobic conditions, created by historic water table elevations that no longer exist.

It would be difficult, if not impossible, to determine what plant species will be present at a mitigation wetland site at some time after a five-year evaluation is performed 
because of the sensitivity of hydrophytic plant species to varying hydrologic regimes. In addition, the presence of hydric soils cannot reliably be used to determine the longevity of a mitigation wetland. Monitoring hydrologic regimes for the development of hydrologic models of young constructed wetlands would help to determine if site hydrology is stable. Moreover, data from hydrologic studies could be used to refine existing design models so predicting future hydrologic regimes would be more precise.

Wetland formation is dependent on topographic relief and topography forming processes. Because of the mountainous topography and the lack of recent glaciation, relatively few natural wetlands occur in West Virginia (Dahl 1991). Therefore, efforts to mitigate unavoidable impacts to wetlands are important in West Virginia and other states in the Appalachian Mountain Region.

Most natural wetlands have several natural functions (habitat, nutrient source/sink, floodwater retention, etc.), but only one primary function generally exists (National Research Council 2001). It is relatively easy to create an area that has the three fundamental characteristics of a wetland (vegetation, soils, and hydrology), but it is much more difficult to create an area that functions in the same manner as the area being impacted (National Research Council 2001). Further, the success of wetland mitigation projects should not be based only on the presence of wetland conditions, but on recreating the function and features of the impacted wetland. Therefore, mitigation projects should be designed to perform the same primary function as the impacted natural wetland for which mitigation is being performed.

It would be impractical to develop a hydrologic model for every constructed wetland. More time should be spent on acquiring the basic understanding of the 
hydrologic regime (Anderson and Woessner 1992). In addition, a substantial amount of hydrologic, meteorologic, and geologic data are required to develop a comprehensive hydrologic model able to predict water level elevations. In contrast, it is relatively practical and efficient to develop a model of the hydrologic conditions at one site and generalize what variables need to be considered in the development of future mitigation wetlands in similar conditions.

\subsection{GOALS AND OBJECTIVES}

The principal goal of this study is to increase the probability of success for future mitigation wetland projects by identifying the hydrologic conditions most favorable for wetland development in the study region. To identify the conditions most favorable for wetlands, hydrologic conditions at three constructed mitigation wetlands and one natural reference site were compared. In addition, a numerical groundwater model of a portion of a mitigation wetland site was developed. 


\section{CHAPTER 2.0 BACKGROUND}

Little data of any kind exists on the effectiveness of current design techniques for mitigation wetlands in the central Appalachian Mountain region of West Virginia. The few constructed wetlands that have been evaluated have been assessed based on soil nutrients, wildlife usage, diversity of vascular plants and major wildlife groups, and productivity (Fortney et al. 2000). These studies were directed to determine the productivity and environmental value of the mitigation sites and not necessarily the

mechanisms that were causing the success or failure of the sites. Even though site hydrology is known to be the most important factor in wetland development, these studies did not entail large amounts of time dedicated to the hydrologic regime and how it affects the sites. Therefore, a precise success rate of the design methods used in these projects and the factors affecting their attainment of the intended hydrologic regime is not known.

\subsection{DEFINITIONS OF WETLANDS}

Many different definitions exist for wetlands. While no two definitions of wetlands are the same, many depend on the presence of three attributes (1) hydrophytic vegetation, (2) hydric soils, and (3) wetland hydrology. The discrepancy between differing definitions comes about because of the inconsistency in which of these attributes is required to be present for an area to be considered a wetland.

The United States Scientific Definition defines an area as wetland if it contains one or more of the previously mentioned attributes (Cowardin et al. 1979). Whereas, the regulatory definition of wetlands, as used by the United States Army Corps of Engineers 
(USACE) and the Environmental Protection Agency (EPA) under Section 404 of the Clean Water Act, requires that the area must contain wetland hydrology, hydrophytic vegetation, and hydric soils (Dennison and Berry 1992 and Mitsch and Gosselink 2000). This definition of wetlands is the one of concern for this study.

\subsection{CAUSE OF WETLAND FORMATION}

By definition, wetlands form in areas where the local hydrology supports the presence of hydrophytic vegetation and the formation of hydric soils from the presence of anaerobic conditions caused by seasonally or permantly high groundwater levels. Diehl and Behling (1982) have identified several geologic settings that contribute to wetland formation in the Appalachian plateaus physiographic province of West Virginia. While these geologic settings do help to determine the presence or absence of wetlands, they do not determine the type of wetlands that form (Diehl and Behling 1982).

\subsubsection{Broad alluvial filled valleys}

Alluvial filled valleys occur in maturely developed stream valleys that have attained a temporary base level and are characterized by deposits of alluvial material and very low stream gradients with meanders (Diehl and Behling 1982, Nace and Bieber 1958). Bedrock underlying the valley floor has an obscured influence due to the thickness of the fine-grained, poorly drained alluvial material. Figure 2.2.1.1 shows a cross section for a typical broad alluvial filled valley. 


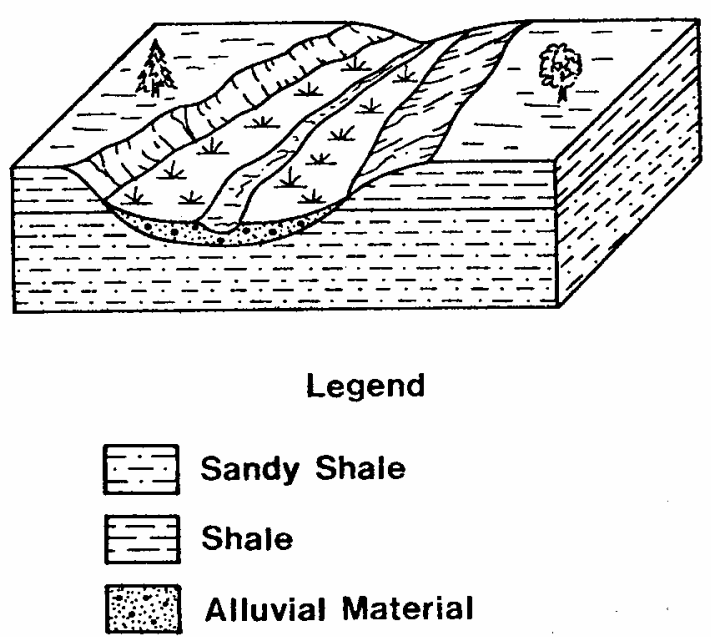

Figure 2.2.1.1. Cross-section of broad alluvial filled valley. (From Diehl and Behling 1982)

\subsubsection{Dipping resistant strata}

Diehl and Behling (1982) found that when dipping resistant strata outcrop in a streambed, a knickpoint will develop. This knickpoint will generally act to increase the downstream gradient while the upstream gradient will to tend to decrease. The decreased stream gradient above the knickpoint is a result of the weathering of non-resistant strata to a temporary base level. Once the temporary base level is reached and the stream energy is diverted laterally, erosion acts to create an alluvial fan, which is characterized by soils that are typically poorly drained. The resistant stratum can dip in either the upstream or downstream direction (Figure 2.2.2.1). 

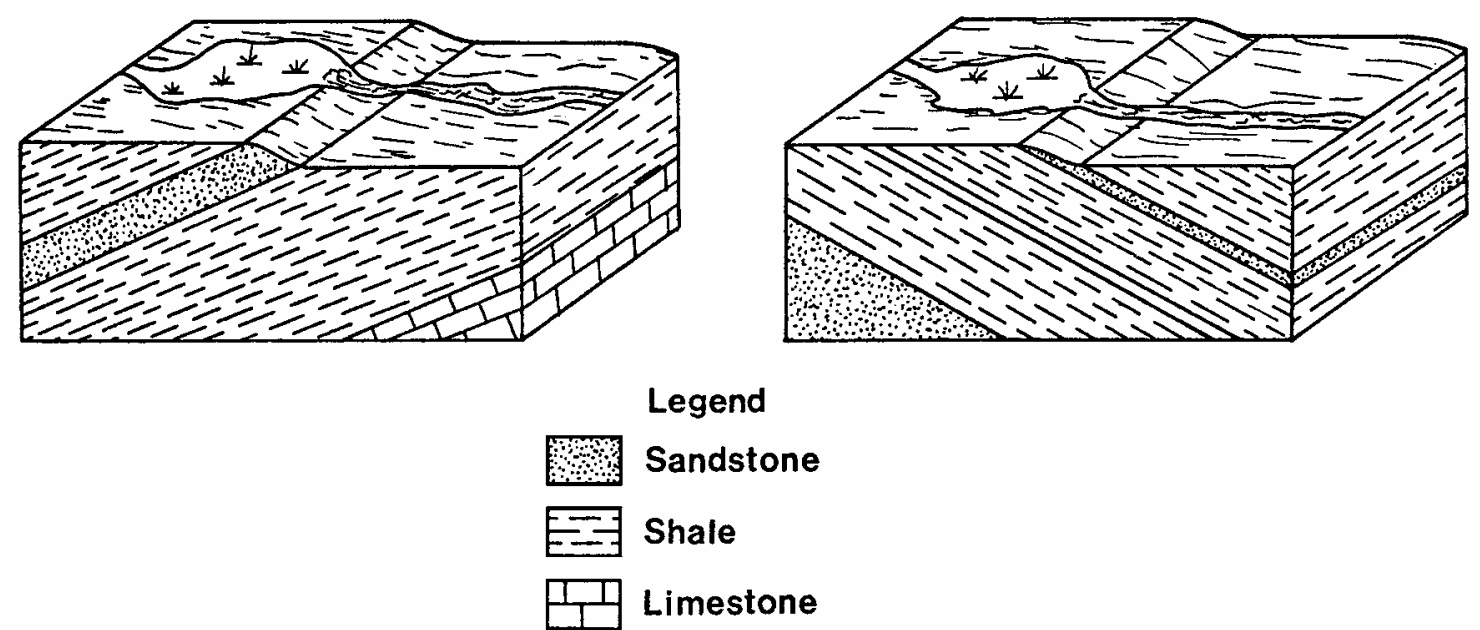

Figure 2.2.2.1. Cross-section of dipping resistant strata. (From Diehl and Behling 1982)

\subsubsection{Dissected plateau with flat-lying strata}

Dissected plateaus with flat-lying strata are characterized by a capping resistant stratum located in a highland area that has been dissected by streams (Diehl and Behling 1982). Wetlands form in this setting on the upgradient side of the reference point where water ponds on the flat or nearly flat-lying strata (Diehl and Behling 1982). While this formation is distinctly different from a knickpoint, the mechanism that causes wetland formation in each setting is similar. Figure 2.2.3.1 shows a typical cross-section for dissected plateaus with flat-lying strata. 


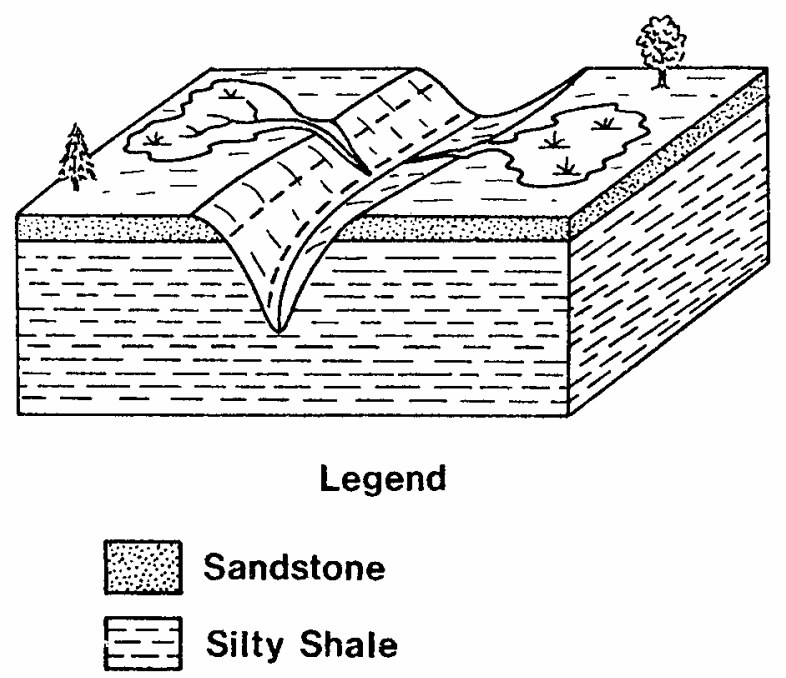

Figure 2.2.3.1. Cross-section of dissected plateau with flat-lying strata. (From Diehl and Behling 1982)

\subsubsection{Other geologic formations}

Breached anticlines form when overlying resistant strata are breached revealing underlying less resistant strata that erode at a higher rate until another layer of resistant strata is reached, leaving behind a central ridge formed in the valley parallel to the longitudinal axis. Exposed resistant strata in the streams that exit the valley act as knickpoints and typically cause the formation of wetlands along the anticlinal axis (Diehl and Behling 1982).

In addition to these natural geologic formations, anthropogenic excavation can lead to wetland formation given that (1) a reliable water source is present, (2) a slowly permeable substrate is present under the excavated site, and (3) surface drainage from the area has been impeded (Diehl and Behling 1982). There are numerous situations where this type of wetland formation can occur; however this formation will not be discussed in detail. 


\subsection{WETLAND FUNCTION AND VALUE}

The inherent dynamic nature of wetlands caused from daily, seasonal, or yearly changes in water level along with complex water regimes and stratified vegetation creates a wealth of niches that combine to make important wildlife habitat (Hammer 1992). Wetlands not only provide a unique and often necessary ecosystem for many types of plants and animals, but they also provide a variety of other functions ranging from floodwater retention to improved water quality. In addition to the wide range of functions wetlands serve for many differing biota, they also provide economic value to humans.

\subsubsection{Floodwater Retention}

Wetlands act to store floodwaters during storm events by absorbing precipitation into the soil and by creating a wider floodplain, which subsequently reduces stream velocities and peak discharge (Smith and Michael 1982). The ability of wetlands to store surface waters and slowly release the stored waters back into the stream system helps to reduce the flood pulse. The reduction in peak velocities associated with wetlands is responsible for reduced erosion downstream of wetland complexes (Tiner 1984). It has been found that the most important factor in determining the effectiveness of wetlands in retaining floodwater is not the total area of wetlands present in a given drainage basin but the percentage of the basin that is covered by wetlands (Smith and Michael 1982).

\subsubsection{Water Quality}

Wetlands can alter water quality through a variety of mechanisms ranging from deposition of sediment because of decreased water velocities to chemical transformations. Carter et al. (1978) found that when rivers overflow their banks and 
enter into their floodplain, approximately 10 to 20 percent of the sediment load can be deposited, depending on the total detention time. Aquatic plants, fungi, bacteria, and hydric soils, found in wetlands, play an important role in the reduction and removal of nutrients and a variety of organic and inorganic chemicals from surface and groundwaters (Metzler and Tiner 1992, Dennison and Berry 1993).

\subsubsection{Productivity}

Wetlands act to receive, hold, and recycle nutrients supplied from adjacent upland and bottomland habitats, providing food, both directly and indirectly, for a vast array of plant and animal species (Hammer 1992). Detritus formed in headwater wetlands often enters into adjacent aquatic ecosystems to serve as a primary source of nutrient supply. Plant productivity is typically extremely high in wetland ecosystems, providing the primary food source for most wetland, as well as many non-wetland, animal species (Dennison and Berry 1993).

\subsubsection{Wetland Values}

Wetland value differs from function in the sense that the term value implies an anthropogenic importance. Value is often the result of subjective interpretation and therefore should not be the basis for determining the importance of wetlands (Fortney et al. 2000, Dennison and Berry 1993). But it is important to briefly discuss the anthropogenic value wetlands possess. Hunters and wildlife enthusiasts spend billions of dollars each year on travel expenses and equipment associated with wetland habitats (Hammer 1992). In addition, many species of commercial fishes depend on wetlands at some stage in their life.

Wetland flora and fauna also comprise a large number of endangered 
species (Dennison and Berry 1993). Of the 595 plant and animal species listed as endangered or threatened by the United States Fish and Wildlife Service in 1991, 60 percent of threatened and 40 percent of endangered species were wetland dependent (Feierabend 1992).

\subsection{CAUSES OF WETLAND LOSS}

Wetland areas have been anthropogenically altered by draining to be used for agricultural land, urban areas, industrial sites, home sites, and waste dumps (Smith and Smith 2001). Of the approximate 89.5 million hectares of wetlands that were in existence in the "lower 48 " United States in 1780 , only 42.2 million hectares were in existence in the mid-1980's, a decline of over 50 percent. West Virginia saw a decline from 54 thousand hectares to 41 thousand hectares or a 24 percent reduction in wetland area during the same time frame (Mitsch and Gosselink 2000). This loss of wetland area in West Virginia, while not as great as other states, is vitally important to the state's ecosystem. The fact that West Virginia has a relatively small amount of natural wetlands makes it necessary that wetland mitigation projects meet their goals.

\subsection{REASONS FOR WETLAND MITIGATION}

Numerous local, state, and federal wetland protection laws exist, varying in the degree of wetland protection they provide. While the intents of this legislation are well directed, the overall effectiveness is the subject of much criticism. Even with all of the differing forms of protection, not all wetlands are protected. 


\subsubsection{Section 404 of the Clean Water Act of 1972}

Section 404 of the Clean Water Act requires a permit for the deposit of fill and dredge materials into all "waters of the United States", which by definition includes wetlands (Dennison and Berry 1993). This law does not prohibit the destruction of all wetlands, but acts to regulate the loss of wetland areas.

\subsubsection{Executive Order 11990}

Executive Order 11990 (Protection of Wetlands), issued in May 1977 by President Jimmy Carter, requires all federal agencies to consider wetland protection as an important part of their policies:

"Each agency shall provide leadership and shall take action to minimize the destruction, loss or degradation of wetlands, and to preserve and enhance the natural and beneficial values of wetlands in carrying out the agency's responsibilities..." (Carter 1977).

\subsection{3 "No Net Loss"}

The policy of "No Net Loss", which was presented in 1987 at a National Wetlands Policy Forum held by the Conservation Foundation at the request of the United States Environmental Protection Agency, formulates one overall objective:

“...to achieve no overall net loss of the nation's remaining wetlands base and to create and restore wetlands, where feasible, to increase the quantity and quality of the nation's wetland resource base" (National Wetlands Policy Forum 1988).

This policy implies that "No Net Loss" includes the construction and restoration of mitigation wetlands to replace natural wetlands impacted by roadway construction and maintenance and other human development (Mitsch and Gosselink 2000). 


\subsection{TYPES OF MITIGATION}

Mitigation measures encompass any measures taken in order to avoid, minimize, or compensate for undesirable effects (Erickson et al. 1980). There are three types of compensation used for wetland mitigation: (1) preservation or protection, (2) restoration, and (3) creation. Preservation and protection are performed by purchasing existing wetland area and prohibiting future development. Wetland restoration is the act of restoring previously existing wetlands from disturbed or altered conditions. Wetland creation is the act of altering or manipulating an existing and historically non-wetland area with the intent of creating new wetland habitat.

\subsection{MITIGATION WETLAND CONSTRUCTION METHODS}

Two general types of construction techniques have been developed for wetland mitigation. These techniques are restoration and creation.

\subsubsection{Restoration Techniques}

The first and most preferable construction method uses restoration techniques in areas that were historically wetlands but were recently drained for other land uses (e.g. agriculture). Sites that historically existed as wetlands and have been subjected to moderate disturbances can contain much of the original seed bank for hydrophytes, and recreating hydrologic conditions suitable for wetland development can quickly restore much of the original wetland vegetation. When using this method, previous conditions should be determined and then restored by reestablishing the historic hydrologic conditions. In areas that have been drained by use of drainage tiles and ditches, reestablishment of hydrologic conditions can often be performed by removing drainage 
structures. But this is not guaranteed to work because adjacent sites that are still drained may not allow the site to restore itself to historic conditions. Other areas that have been filled can be restored by excavating to the original wetland ground elevation and placing topsoil, so long as no major alterations to the local and regional flow systems have occurred since the time of filling (Hammer 1992).

\subsubsection{Creation Techniques}

Currently there are three methods being employed for wetland creation in West Virginia. These methods are excavation to groundwater, liner installation to create a perched water table, and the use of berms to control surface water runoff. These three methods are often used in conjunction with one another to provide better control over the intended hydrologic regime. A fourth method, the installation of a vertical hydraulic barrier to impede groundwater flow and thus raise the groundwater table, is under investigation.

\subsubsection{Excavation}

Excavation of the existing ground surface to the water table depth is probably the most common practice for wetland mitigation construction. This method consists of excavating the existing grade down to the groundwater table and placing a minimum of $15 \mathrm{~cm}$ (preferably $30 \mathrm{~cm}$ to $45 \mathrm{~cm}$ ) of topsoil with similar organic and nutrient contents as that of natural wetland soils (Dennison and Berry 1993). It is recommended that topsoil from the impacted natural wetland be salvaged and used as the topsoil layer in the new mitigation wetland area (Hammer 1992). Soil permeability in the new mitigation areas should be capable of allowing free vertical and horizontal movement of water. Bottom slopes in the mitigation wetland development area should be a maximum of 
$1 \mathrm{~V}: 10 \mathrm{H}$, with $1 \mathrm{~V}: 15 \mathrm{H}$ to $1 \mathrm{~V}: 20 \mathrm{H}$ being preferable to mimic natural wetlands (Dennison and Berry 1993).

\subsubsection{Excavation and Installation of Low Hydraulic Conductivity Liner}

As shown in Figure 2.7.2.2.1, this technique lowers the existing grade to a predetermined depth, but also includes the installation of a low hydraulic conductivity liner, typically compacted clay, with a minimum thickness of $30 \mathrm{~cm}$ (USACE 2000). The liner is installed in areas where it is determined that excavation to the existing groundwater table would be impractical. This method acts to create a perched water table and forces the area to be almost solely dependent on surface water runoff and precipitation.

To create the liner, compaction of onsite materials will suffice unless the hydraulic conductivity is greater than $1 \times 10^{-6} \mathrm{~cm} / \mathrm{s}$ or $1 \times 10^{-7} \mathrm{~cm} / \mathrm{s}$, in which case borrow material will be needed (Hammer 1992). After liner construction, placement of $15 \mathrm{~cm}$ to $30 \mathrm{~cm}$ of topsoil is recommended to provide a root zone (USACE 2000). A buffer layer comprised of medium textured soils should be placed between the liner and topsoil to provide protection for the liner against erosion and root penetration (USACE 2000). The topsoil layer grain size should be smaller than the buffer layer to promote the rise of water through capillary action (USACE 2000). Dennison and Berry (1993) state that the bottom slopes in these areas should be minimal, $1 \mathrm{~V}: 10 \mathrm{H}$ to $1 \mathrm{~V}: 20 \mathrm{H}$. 


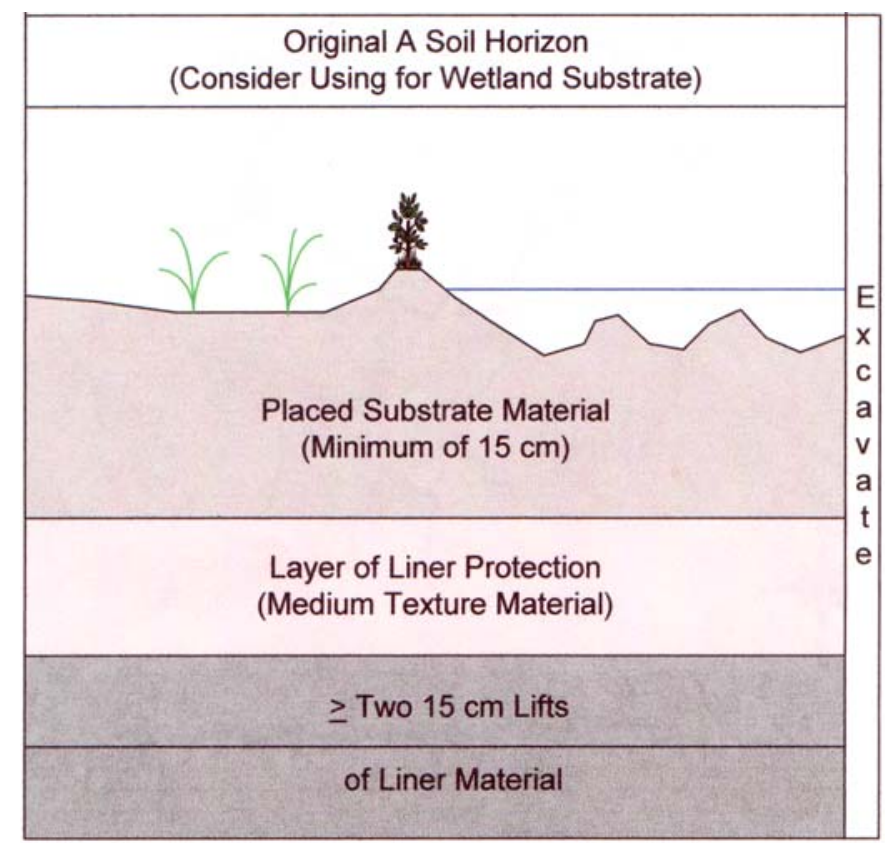

Figure 2.7.2.2.1. Typical cross-section of excavation and installation of low hydraulic conductivity liner. (From USACE 2000)

\subsubsection{Berms}

The use of berms to control surface water in constructed wetlands is a common practice in West Virginia. Berms are used along the perimeter and internally to control surface water elevations and promote vegetative species diversity. Berms typically range in top width from 1 to $3 \mathrm{~m}$ and in height from 1 to $5 \mathrm{~m}$ (Fortney et al. 2003). Fortney et al. (2003) found that periphery berms often limit the access of adjacent streams to their floodplains and create high energy systems at outlet devices leading to excessive erosion and increased maintenance. In addition, these structures are highly susceptible to integrity problems from beaver and muskrat activity. 


\subsection{EFFECTIVENESS OF WETLAND MITIGATION CONSTRUCTION}

Because of the time that is required for wetlands mitigation project sites to reach maturity, the true effectiveness of wetland mitigation techniques is not yet known in the study region. However, it is apparent that this technology is still in the early phases of development. For a variety of reasons, ranging from poorly conceived designs to improper construction techniques, not all wetland mitigation sites are developing as intended. While the major portions of most sites are developing satisfactorily, areas exist where inadequate water inputs are being experienced. 


\section{CHAPTER 3.0 METHODS}

In this chapter, the methods used for the study are described. The study site selection process, the methods used to collect and analyze hydrologic, geotechnical, topographic, and meteorologic data, and the development of the hydrologic model are presented.

\subsection{SITE SELECTION}

The Leading Creek, Triangle, and Sugar Creek mitigation wetland sites were selected because of the techniques used to construct them, their location, and their age. The Meadowville natural wetland was chosen as the reference site due to its composition and relative proximity to the three study areas. All of the study sites area in the Appalachian plateaus physiographic province. Figure 3.1.1 shows the location of the study sites. 


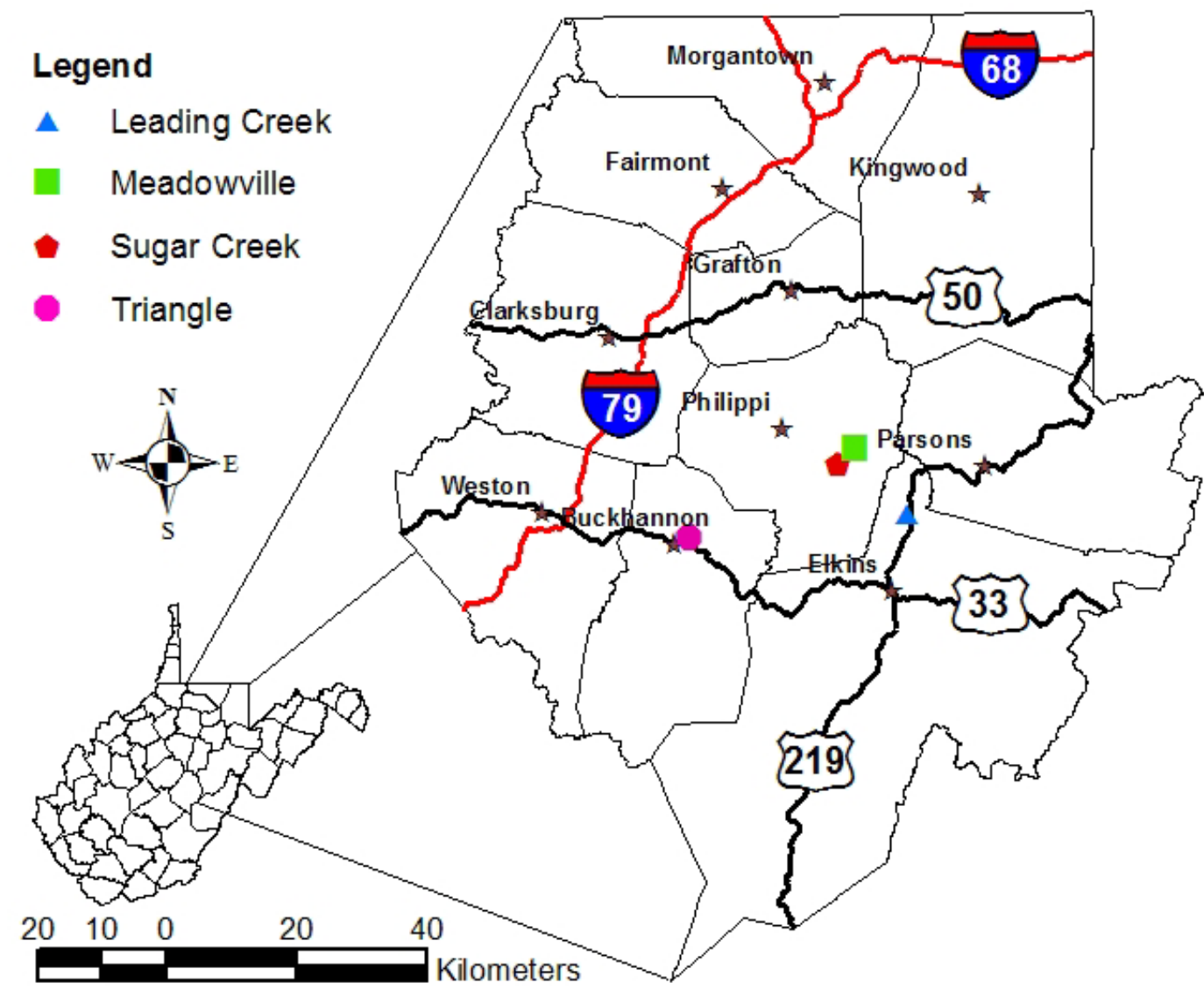

Figure 3.1.1. Regional map of study area showing site locations, county seats, and major highways.

\subsubsection{Leading Creek}

The Leading Creek mitigation wetland (4321134N, 602584E, EL = $602 \mathrm{~m}$ ) was constructed in the fall season of 1996, with its first full growing season being in 1997. The Leading Creek mitigation wetland is located about $13 \mathrm{~km}$ northeast of Elkins, West Virginia, along US Route 219 (Figure 3.1.1). The site is approximately 16 hectares in size and is dominated by emergent persistent vegetation with dispersed patches of scrubshrub and open water habitat (Balcombe 2003, Figure 3.1.1.1). This site is comprised of several cells located on either side of Leading Creek, which flows from north to south. 
Two of these cells were investigated during this study (Figure 3.1.1.1)

The eastern cell is rectangular with an area of approximately 5.4 hectares and dimensions of $290 \mathrm{~m}$ by $220 \mathrm{~m}$ at the widest locations (Figure 3.1.1.1). This area receives surface water in the northeastern corner of the area from a culvert that runs under US Route 219.

The western cell is located on the opposite side of the stream and is rectangular in shape with an area of approximately 7.8 hectares and dimensions of $650 \mathrm{~m}$ by $175 \mathrm{~m}$ at its widest locations (Figure 3.1.1.1). Groundwater, surface runoff from the hillside to the west, and a natural seep along the northwestern corner are the primary sources of surface water input into this area.

The Leading Creek site was designed to be constructed by excavation and placement of a clay liner. The pre-construction grade was lowered approximately $1.5 \mathrm{~m}$ to $2.0 \mathrm{~m}$. When construction began, problems were encountered that did not allow a liner to be installed throughout the entire site. The heavy machinery used to construct the site began to sink after the surface layer of soil was removed. Therefore, a liner material could not be placed and compacted. In addition, berms were placed along both banks of Leading Creek. These berms were constructed by leaving onsite material in place. The berms vary in height from $1.5 \mathrm{~m}$ to $2 \mathrm{~m}$, depending on the amount of excavation that took place at that location, and top their width varies from $3 \mathrm{~m}$ to $4 \mathrm{~m}$. 


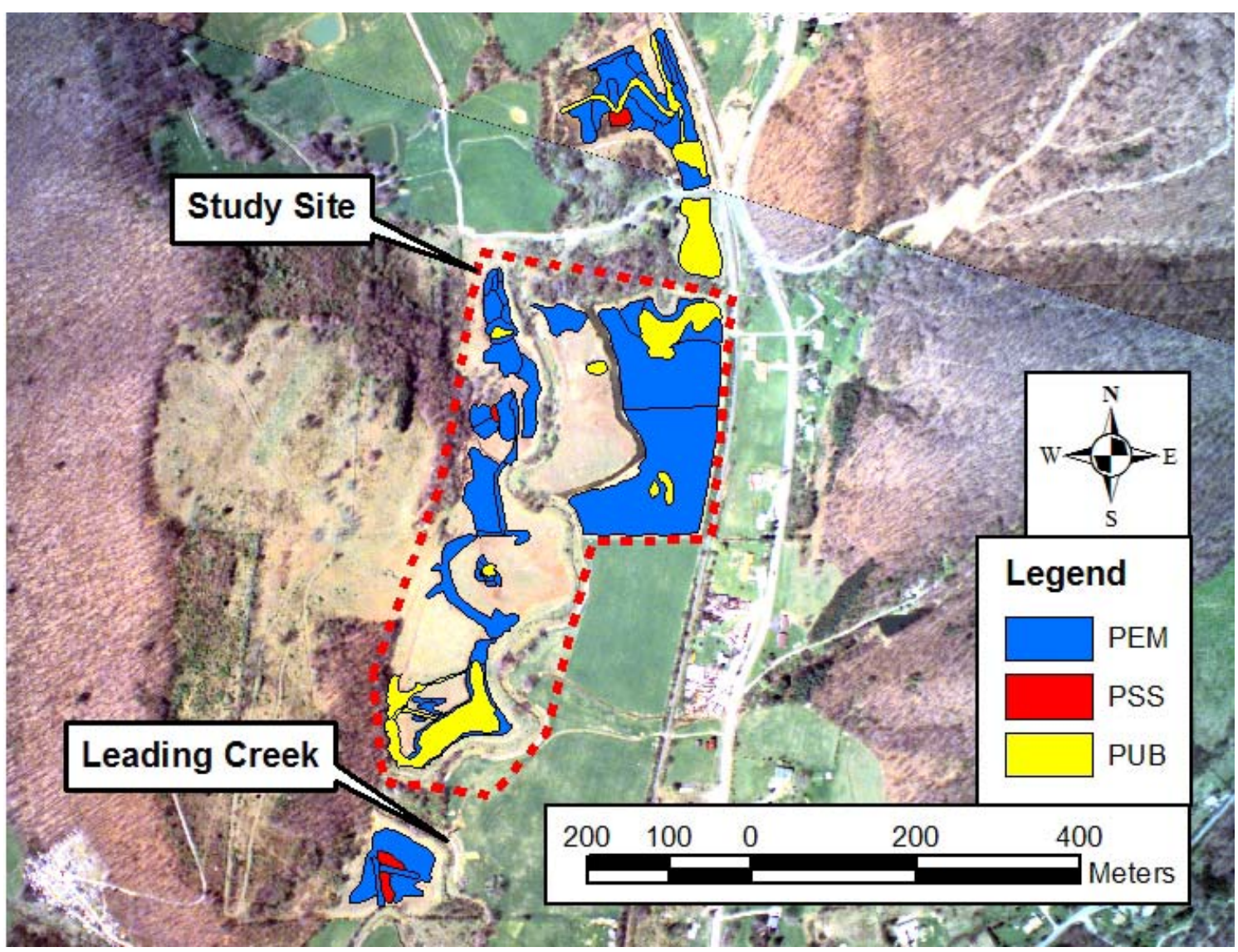

Figure 3.1.1.1. Aerial photograph of the Leading Creek mitigation wetland showing wetland classification and study area. (Aerial photograph provided by Natural Resource Analysis Center at West Virginia University) Note: $\mathbf{P E M}=$ Palustrine emergent persistent, $\mathrm{PSS}=$ Palustrine scrub-shrub, and PUB = Palustrine unconsolidated bottom

\subsubsection{Sugar Creek}

The Sugar Creek mitigation wetland $(4328871 \mathrm{~N}, 591442 \mathrm{E}, \mathrm{EL}=479 \mathrm{~m})$, constructed in 1995, is one year older than the Leading Creek site and is located $15 \mathrm{~km}$ north of Elkins, West Virginia near WV State Route 92 (Figure 3.1.1). The 7 hectares comprising the Sugar Creek site are dominated by emergent persistent and open water habitat with small patches of scrub-shrub vegetation (Balcombe 2003, Figure 3.1.2.1). In 
addition, a complex series of berms was installed to help retain and control surface runoff.

The northern and two western cells were constructed using excavation and placement of liner. The total area of these cells is 5.2 hectares. Berms were installed around each of these cells to help control surface runoff. Groundwater, surface flow, and direct rainfall appear to be the primary sources of water into these areas.

The southern cell was constructed using excavation. The area of this cell is 1.8 hectares. Berms were also constructed along the edges of this cell. Also contained in this area are pockets of existing wetlands that were not disturbed during construction. Groundwater, surface flow, rainfall, and occasional overbank flooding from Sugar Creek are the primary sources of water. 


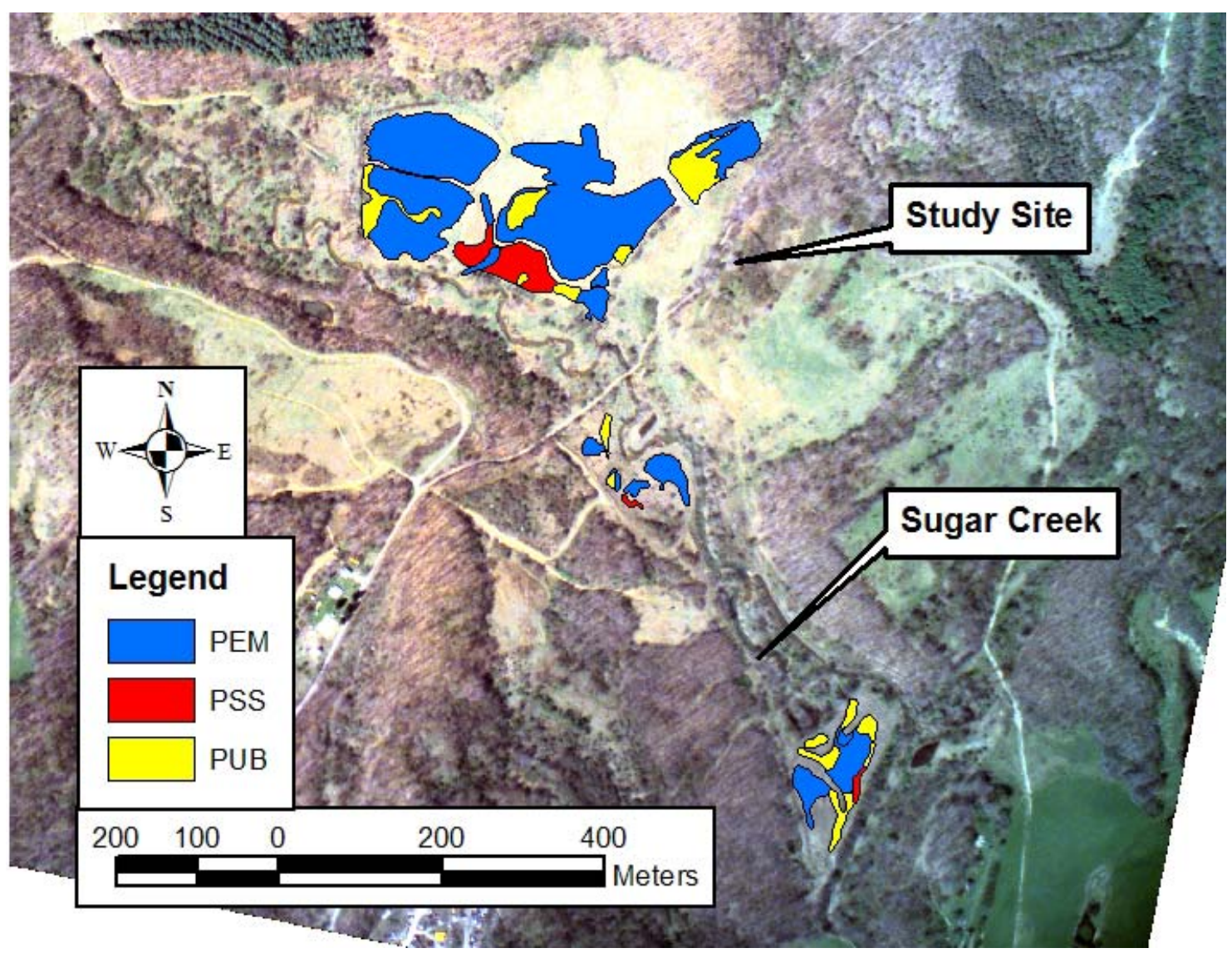

Figure 3.1.2.1. Aerial photograph of the Sugar Creek mitigation wetland showing wetland classification and study area. (Aerial photograph provided by Natural Resource Analysis Center at West Virginia University)

\subsubsection{Triangle}

The Triangle mitigation wetland $(4316939 \mathrm{~N}, 568438 \mathrm{E}, \mathrm{EL}=427 \mathrm{~m})$ is the oldest of three constructed sites, having been built in 1991. The 3.5 hectare site is located adjacent to Appalachian Corridor H (S.R. 33) approximately 2 km east of Buckhannon, West Virginia (Figure 3.1.1). As with the Leading Creek and Sugar Creek sites, Triangle was designed for the installation of a clay liner but due to construction problems only intermittent areas of liner were installed. The site is dominated by emergent persistent vegetation and areas of open water with patches of scrub-shrub (Balcombe 2003, Figure 
3.1.3.1). While being one contiguous area, this wetland can be divided into two cells that are separated by a constructed berm.

Approximately seventy percent of the site was designed and constructed using the excavation and liner placement method. The remainder of the area was constructed at a higher elevation with no liner due to construction problems (e.g. sinking of heavy equipment) that prohibited the intended elevation from being reached.

Groundwater, surface water runoff, rainfall, and occasional flooding appear to be the primary sources of water in both cells. A berm, similar in size to that of Leading Creek, was constructed along the Buckhannon River to control flooding frequency. In addition, this berm controls surface water elevations in the ponded areas. 


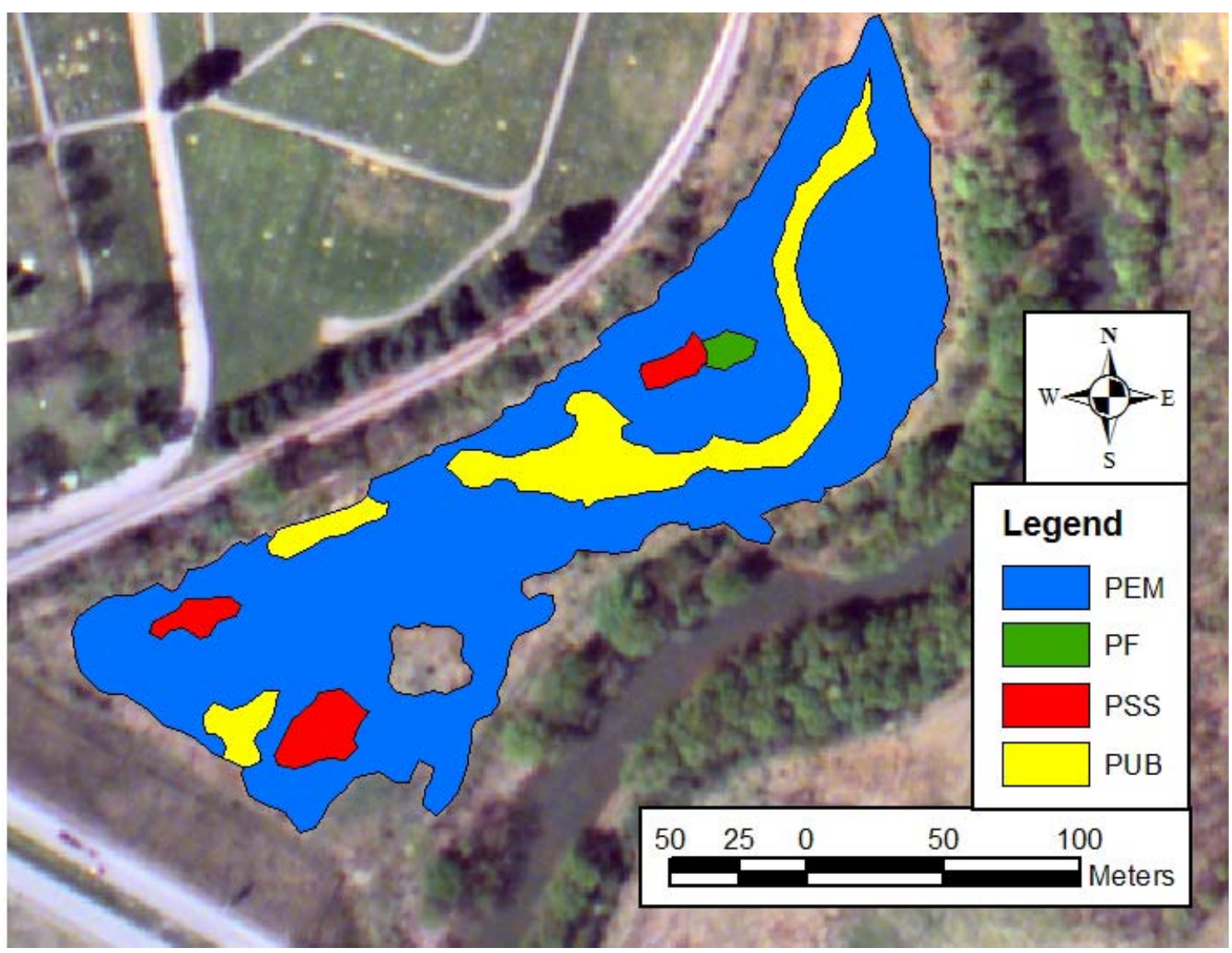

Figure 3.1.3.1. Aerial photograph of the Triangle mitigation wetland showing wetland classification and study area. (Aerial photograph provided by Natural Resource Analysis Center at West Virginia University) Note: $\mathbf{P F}=$ Palustrine forest

\subsubsection{Meadowville}

The Meadowville natural wetland area $(4330850 \mathrm{~N}, 493033 \mathrm{E}, \mathrm{EL}=468 \mathrm{~m})$ is located $16 \mathrm{~km}$ north of Elkins, West Virginia, along State Route 92 (Figure 3.1.1). The area was historically used as a grazing pasture but was abandoned approximately 30 years ago when the site became too moist (Fortney, per. com.). The wetland is comprised of a mix of emergent persistent and scrub-shrub habitat (Balcombe 2003, Figure 3.1.4.1). Groundwater, direct rainfall, and surface water runoff are the primary sources of water for the site. 


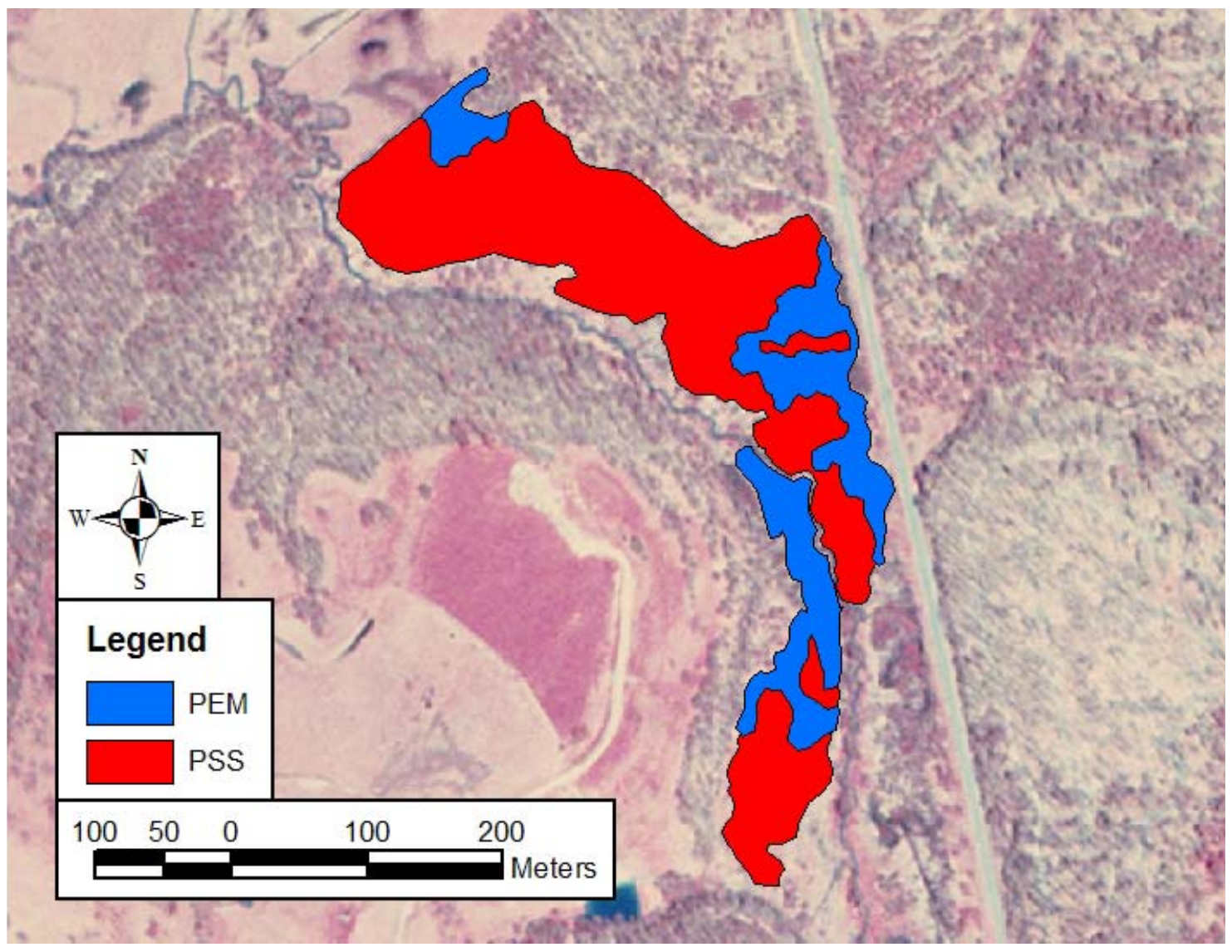

Figure 3.1.4.1. Aerial photograph of the Meadowville reference wetland showing wetland classification and study area. (Aerial photograph downloaded from the West Virginia Department of Environmental Protection, www.dep.state.wv.us)

\subsection{HYDROLOGIC MONITORING DEVICES}

Four types of devices were used for the collection of groundwater level at the study sites. These devices were piezometers, monitoring wells, automated water level recorders, and a water level detector.

\subsubsection{Piezometers}

Piezometers were made of 1-meter sections of $0.02 \mathrm{~m}$ galvanized steel pipe with a $0.30 \mathrm{~m}$ stainless steel screened tip. So that atmospheric pressure differences, between observation times, would not interfere with data readings, the instrument caps were 
placed lightly on the instrument and not tightened. These instruments were relatively expensive compared to monitoring wells and were only installed at locations where the maximum depth to the water table was expected to exceed $1.1 \mathrm{~m}$. Piezometers were installed in 1-meter increments using a $5.4 \mathrm{~kg}$ sledgehammer. It was not expected for the water table at any of the instrument locations to exceed $2.0 \mathrm{~m}$; therefore, only two sections were installed for each of the piezometers. A total of eight of these instruments were installed at the Leading Creek and Meadowville study sites. None of these instruments was installed at the Sugar Creek and Triangle sites since the depth to the water table was not expected to exceed 1.1 m. Figure 3.2.1.1 shows a schematic drawing of a piezometer.

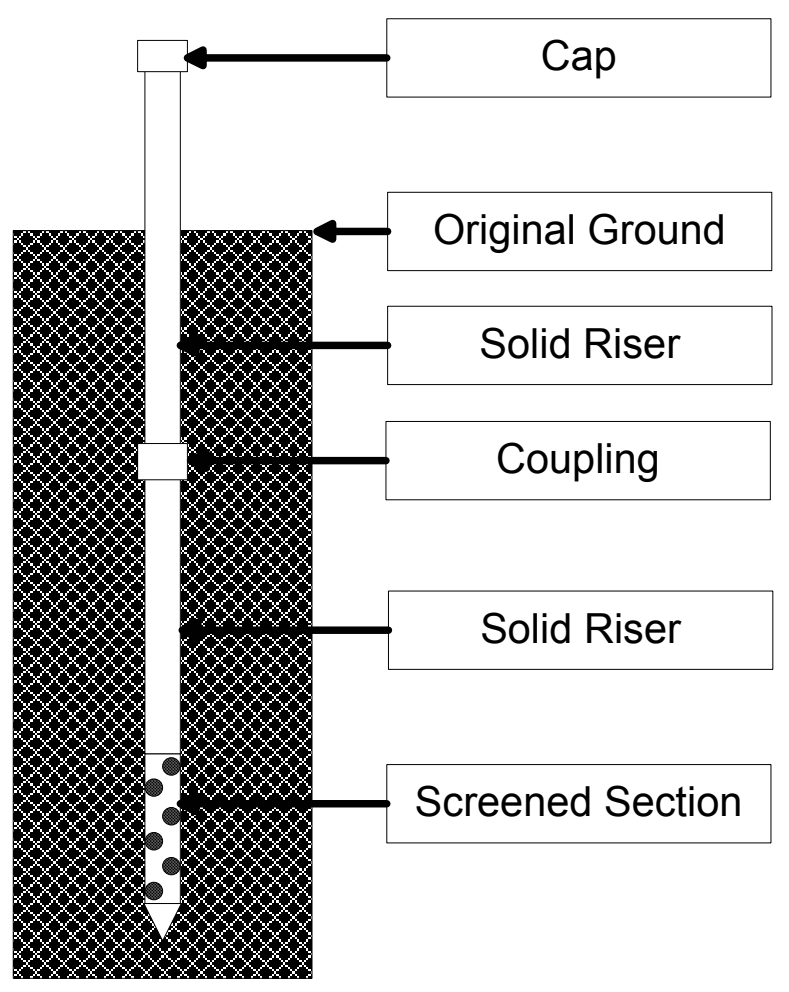

Figure 3.2.1.1. Schematic drawing of piezometer. 


\subsubsection{Monitoring Wells}

Monitoring wells were made of $0.05 \mathrm{~m}$ diameter Schedule 40 PVC pipe with a length of $1.8 \mathrm{~m}$, of which $0.9 \mathrm{~m}$ was screened and $0.9 \mathrm{~m}$ was non-screened. These instruments were preferred over the piezometers because of their relatively inexpensive cost. But the length of the monitoring wells limited their use in areas where the maximum depth to the water table was expected to exceed $1.1 \mathrm{~m}$. These instruments were installed by digging a $0.1 \mathrm{~m}$ diameter hole to a depth of $1.2 \mathrm{~m}$. A $0.1 \mathrm{~m}$ thick layer of industrial quartz sand was then placed at the bottom of the hole. The monitoring well was then placed in the hole and sand was placed around the device to within $0.1 \mathrm{~m}$ from the ground surface to act as a filter. Bentonite pellets were then placed around the monitoring well to the ground surface to prevent surface water from entering the monitoring well. A total of thirty monitoring wells were installed at the study sites.

As seen in Figure 3.2.2.1 vented caps ere used on the instruments. These caps were used because of changes in atmospheric pressure between data collection. As the groundwater table fluctuates vertically, air within the device needs to be able to enter and exit. If air can not enter and exit the device a change in internal air pressure will develop, which will impede the free vertical movement of groundwater in the device. If nonvented caps are used water levels need to stabilize before data readings are taken. 


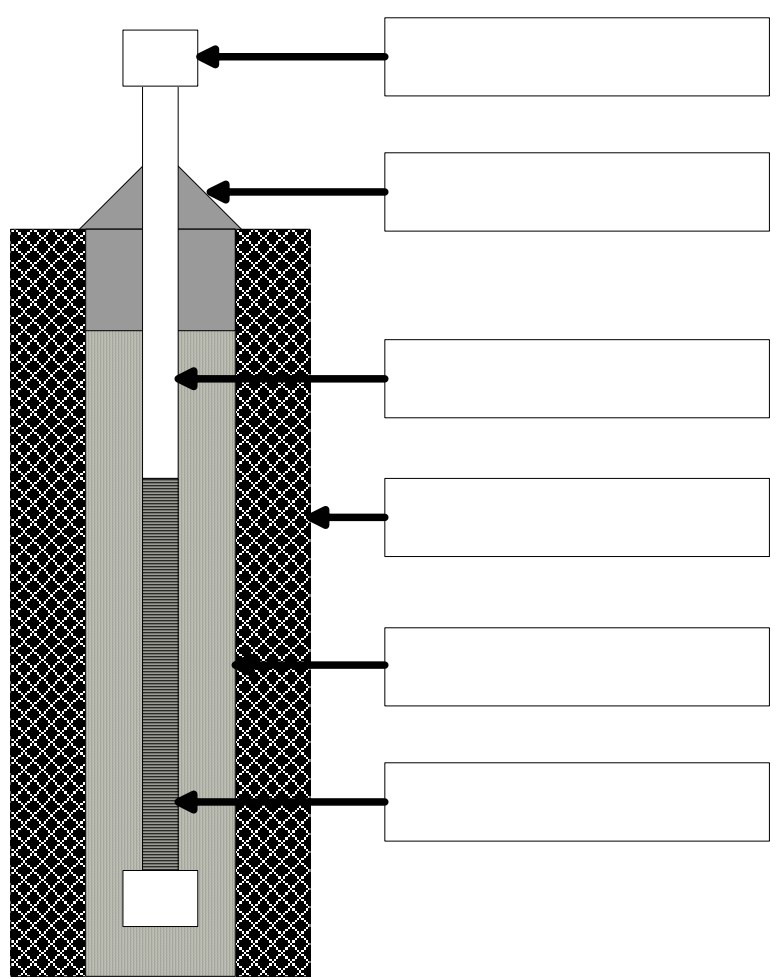

Figure 3.2.2.1. Schematic drawing of monitoring well.

\subsubsection{Water Level Detector}

A SOLINST ${ }^{\circledR}$ Water Level Meter was used to determine the depth to the water table at the monitoring well and piezometer locations. This device consists of a cable with two conductors at the tip. When these conductors are exposed to water the circuit closes and the instrument alerts the user with and audible beep and a visual light. The user then reads the depth to water from the cable, which was marked in $.001 \mathrm{~m}$ increments and was determined during lab tests to be accurate to $0.005 \mathrm{~m}$. The distance from the top of the well to the water table surface was then recorded as the measurement. The height of the top of the well above the ground surface was then subtracted from this measurement to produce the depth below the ground surface to the water table. 


\subsubsection{Automated Water Level Recorders}

Remote Data Systems, Inc. type WL-40 automated water level recorders were used to collect the depth to the water table every three hours at four locations at the Leading Creek and Meadowville study sites. The WL-40 uses a capacitance sensor to measure the depth to the water table (Remote Data Systems, Inc. 2001). These instruments are designed to measure the water level from $0.000 \mathrm{~m}$ to $1.016 \mathrm{~m}( \pm 0.003 \mathrm{~m})$ below the calibration point.

Data from the WL-40, including depth to the water table and date and time of measurement were downloaded in the field using an HP48GX calculator. Data were transferred to through infrared ports located on the calculator and WL-40 following the manufacturer's instructions (Remote Data Systems, Inc. 2001). A cable was then used to download the data from the calculator to a computer, where analyses could be performed.

The automated water level recorders were installed using the same basic method as the monitoring wells. A $1.2 \mathrm{~m}$ deep hole with a diameter of $0.1 \mathrm{~m}$ was dug using a hand auger. This hole was then backfilled $0.1 \mathrm{~m}$ with industrial quartz sand. The automated recorder was inserted into the hole and sand was placed around the instrument to within $0.1 \mathrm{~m}$ of the ground surface. Bentonite pellets were then placed in the hole to the ground surface to prevent the inflow of surface water into the instrument. Figure 3.2.4.1 shows a schematic drawing of an automated water level recorded.

A substantial amount of data was lost because of the reliability of these instruments. Several electrical failures and short-circuiting of internal electronics required the replacement of many of the instruments and data loss. Conversation with the manufacturer revealed that faulty circuit boards had been installed. 


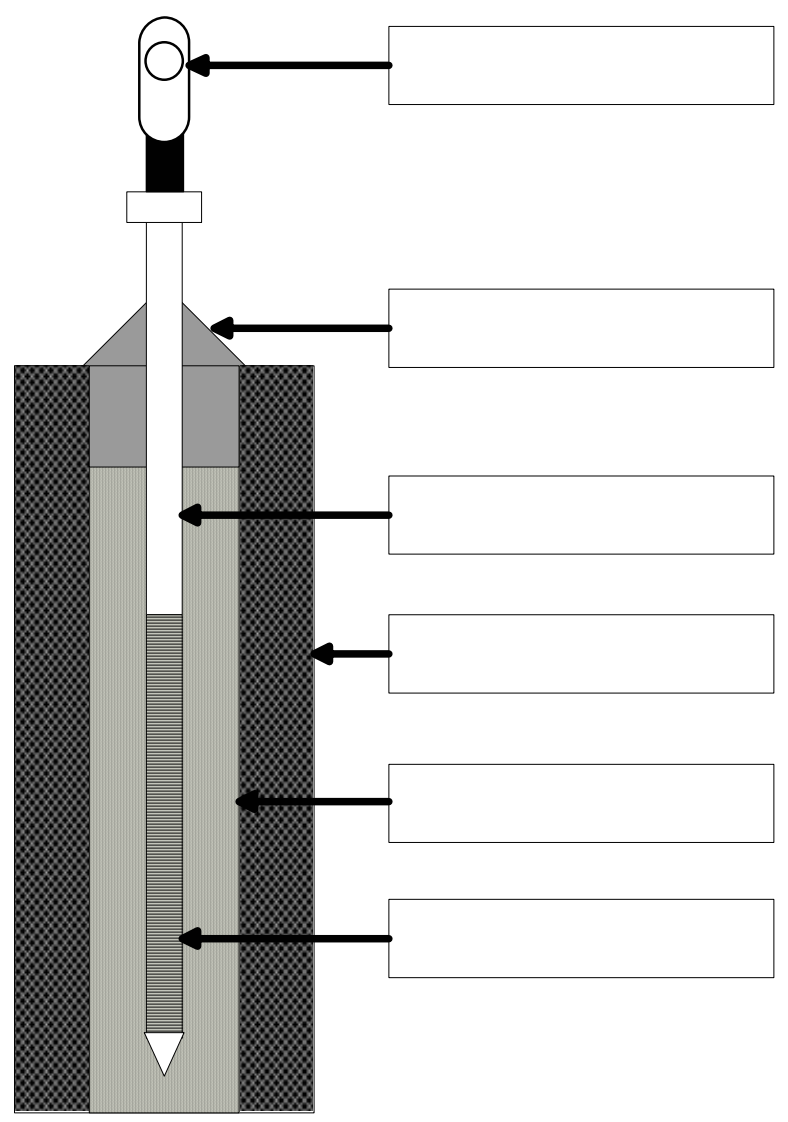

Figure 3.2.4.1. Schematic drawing of automated water level recorder.

\subsubsection{Monitoring Device Location Plan}

Monitoring devices were aligned in transects normal to the stream flow direction (Figures 3.3.1 through 3.3.4). The transects extended from the stream towards the wetland boundary. This pattern provides a logical set of data to determine the horizontal flow directions of groundwater through the sites. 


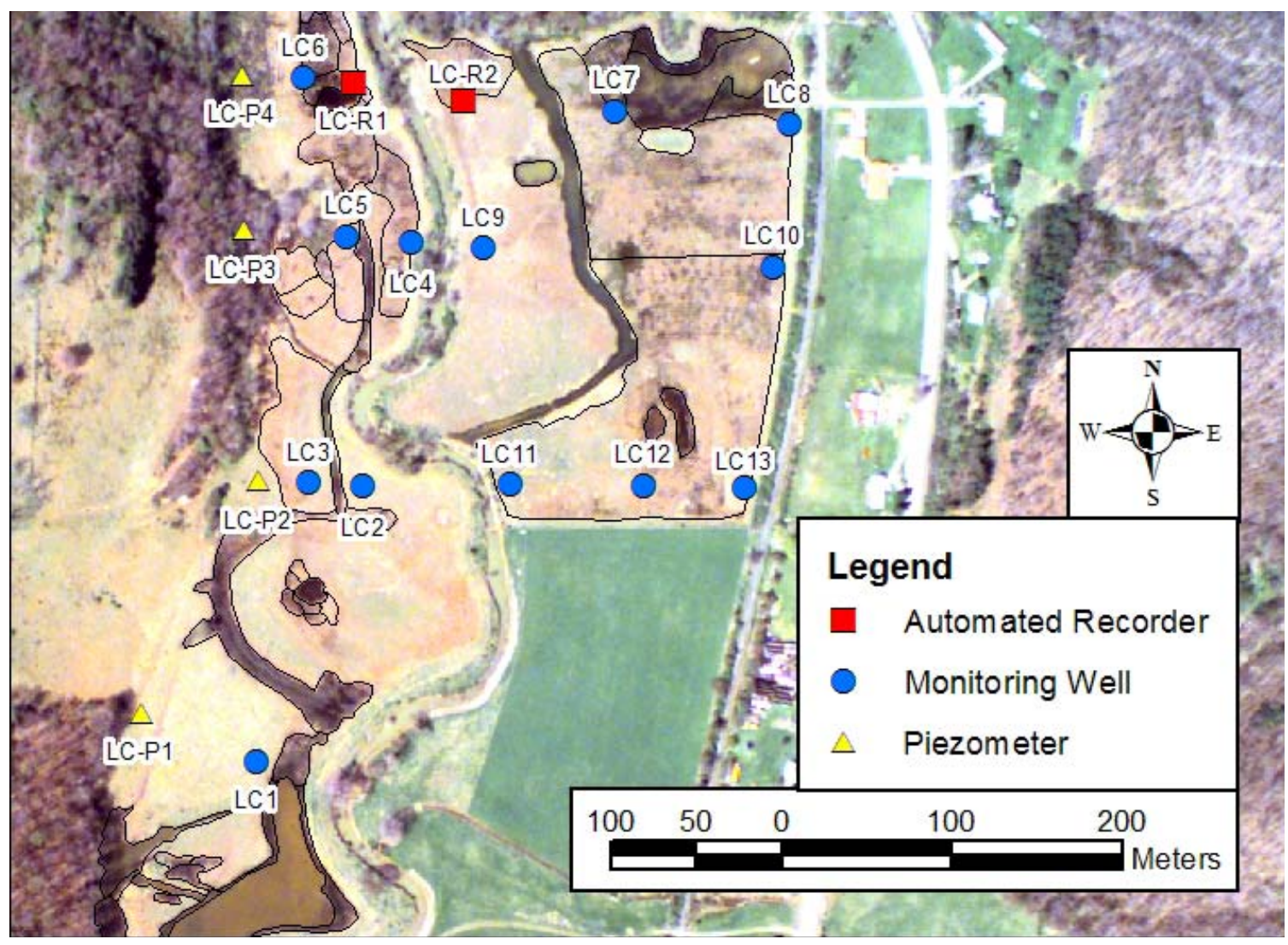

Figure 3.2.5.1. Aerial photograph of the Leading Creek mitigation wetland showing monitoring device locations. (Aerial photograph provided by Natural Resource Analysis Center at West Virginia University) 


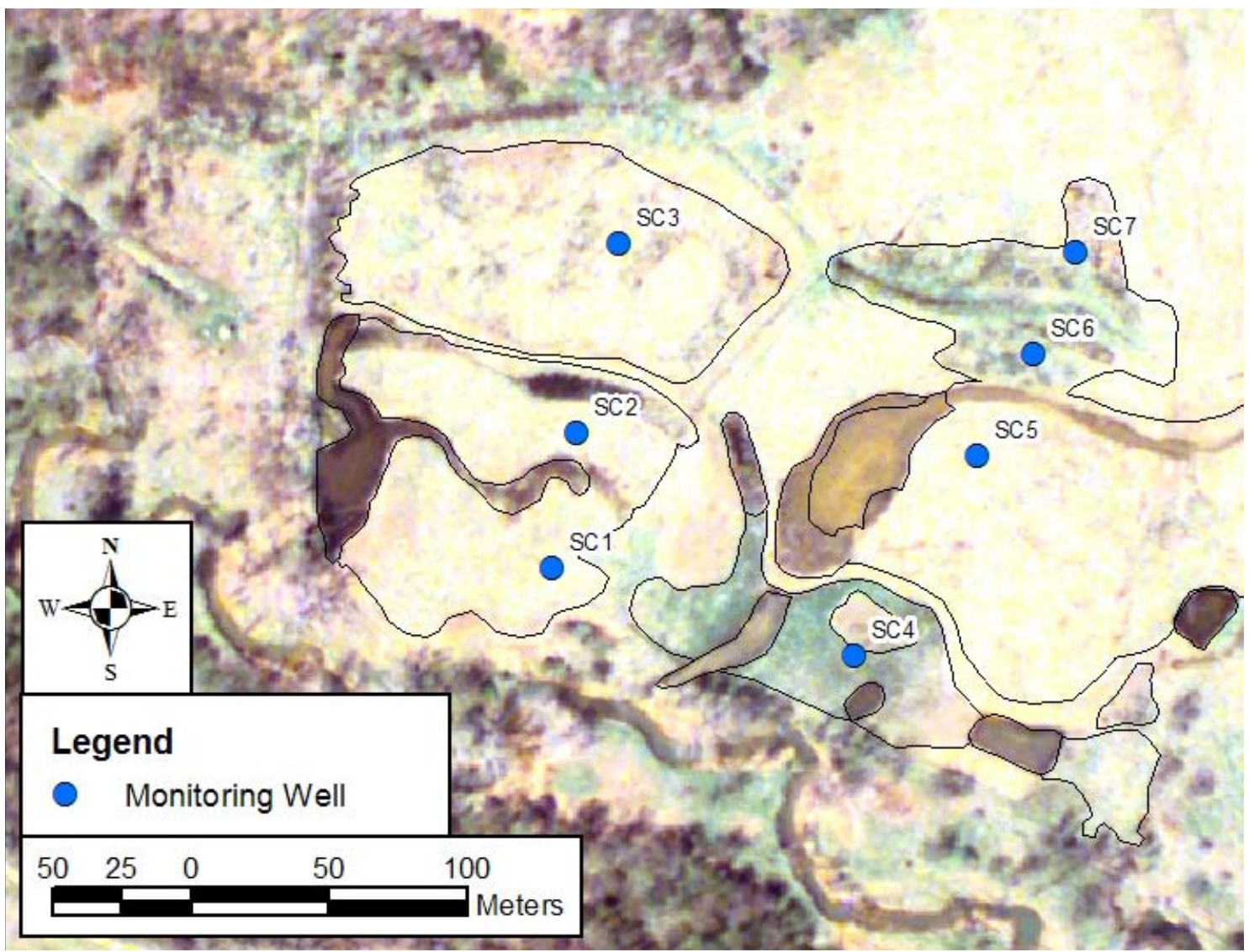

Figure 3.2.5.2. Aerial photograph of the Sugar Creek mitigation wetland showing monitoring device locations. (Aerial photograph provided by Natural Resource Analysis Center at West Virginia University) 


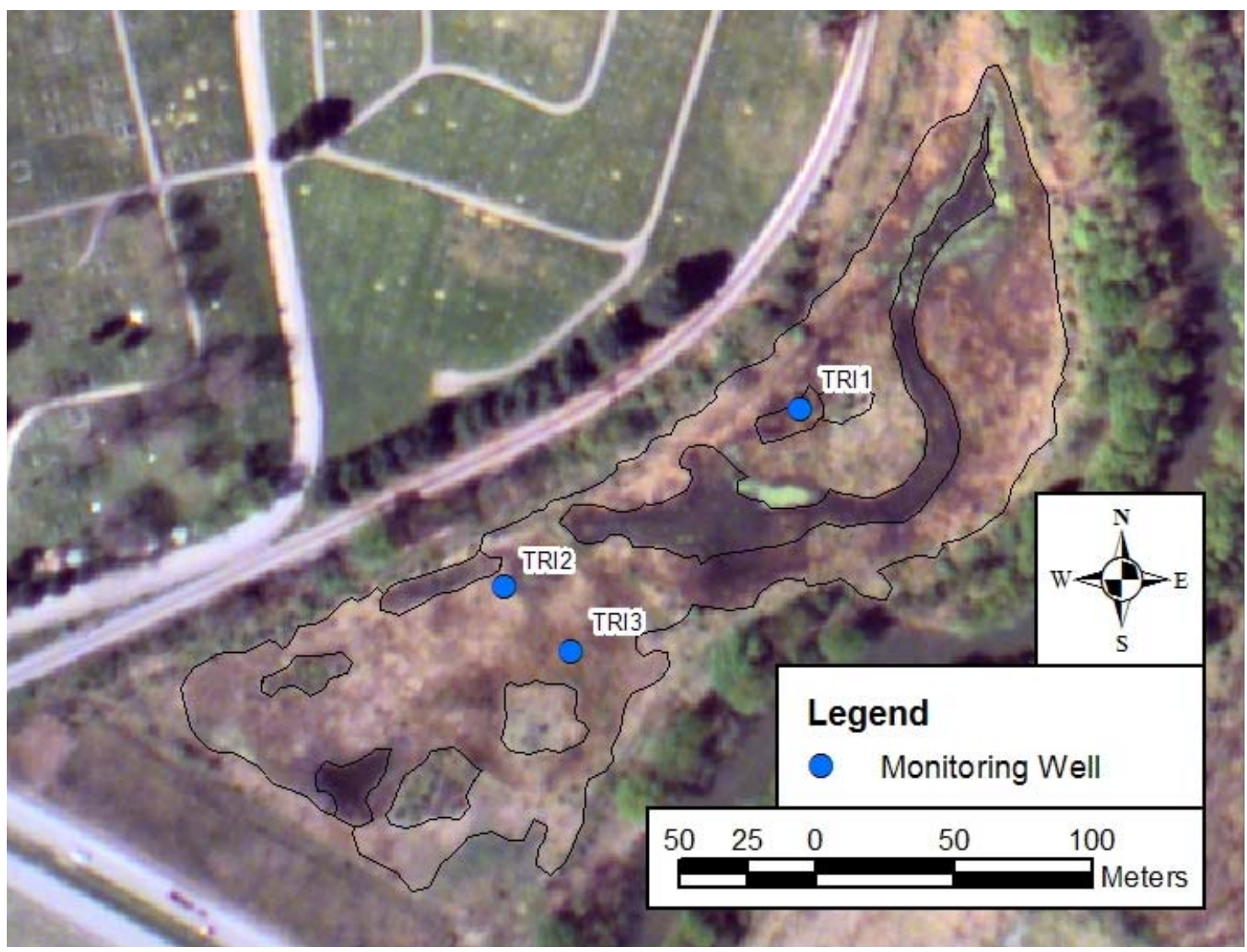

Figure 3.2.5.3. Aerial photograph of the Triangle mitigation wetland showing device locations. (Aerial photograph provided by Natural Resource Analysis Center at West Virginia University) 


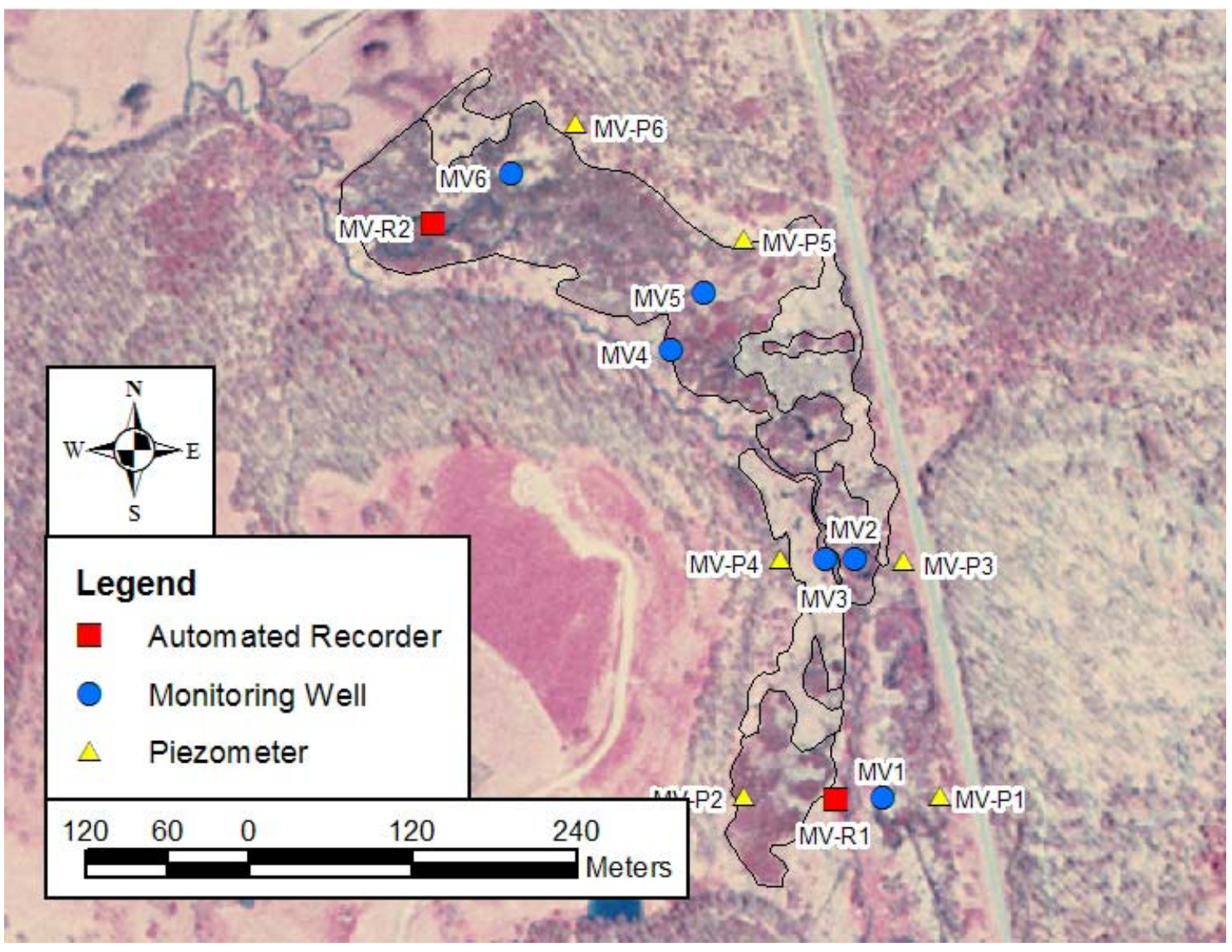

Figure 3.2.5.4. Aerial photograph of the Meadowville reference wetland showing device locations. (Aerial photograph downloaded from the West Virginia Department of Environmental Protection, www.dep.state.wv.us)

\subsubsection{Hydrologic Data Collection}

Data collection at the Leading Creek and Meadowville sites began on a bimonthly basis in May of 2001. The automated recorders at these sites were programmed to take data readings every 1.5 hours and were downloaded at the time of monitoring well and piezometer readings. Data collection at the Triangle and Sugar Creek sites began in August 2001 on a bi-monthly basis. In November of 2001, data collection was reduced to one time per month and the automated recorders were programmed to take readings 
every 3 hours. Data collection continued on this schedule until the end of May 2002 when collection of data at all of the sites ended.

\subsubsection{Hydrologic Data Analysis}

In order to compare the monitoring well data from the study sites, two metrics were determined: mean depth to the water table at each well (Equation 3.2.7.1) and standard deviation of the depth to the water table at each well (Equation 3.2.7.2). These values were used to determine if sufficient amounts of water were present and if persistent sources of water were present.

$$
\bar{x}=\frac{\sum_{i=1}^{n} x_{i}}{n}
$$

where: $\overline{\mathrm{x}}=$ mean, $\mathrm{x}_{\mathrm{i}}=$ measurement value, and $\mathrm{n}=$ number of measurements

$$
\sigma=\sqrt{\frac{\sum_{\mathrm{i}=1}^{\mathrm{n}}\left(\overline{\mathrm{x}}-\mathrm{x}_{\mathrm{i}}\right)^{2}}{\mathrm{n}}}
$$

where: $\sigma=$ standard deviation, $\bar{x}=$ mean, $x_{i}=$ measurement value, and $\mathrm{n}=$ number of measurements

Comparing the mean depth to the water table at the mitigation sites to the natural wetland indicates if a sufficient amount of water is present to support wetland hydrology. The comparison of the standard deviation of the depth to the water table indicates if persistent sources of water (i.e. groundwater) are present. Rainfall is not a constant source of water input because it does not rain continuously. Conversely, groundwater acts as a continual source of water except during extreme drought conditions. Therefore, if the standard deviation is small, the site has a persistent water source (groundwater). 


\subsection{GEOTECHNICAL DATA COLLECTION}

Soil samples were obtained at all of the monitoring well and automated recorder locations at the Leading Creek and Meadowville sites. Bag samples were taken during the installation of the instruments. These samples were analyzed at the West Virginia University Department of Civil and Environmental Engineering Geotechnical Laboratory for water content, grain size distribution, and soil classification. Shelby tube samples were also collected near the instrument locations at the Leading Creek site and were analyzed for water content and vertical hydraulic conductivity. In-situ slug tests were performed at the Leading Creek site to determine horizontal hydraulic conductivity.

\subsection{TOPOGRAPHIC DATA COLLECTION}

Topographic data were collected during October 2001 using a Leica TC600 electronic total station and a HP48GX data collector. In order to eliminate the need to survey off a known control station (CS), an arbitrary coordinate system was developed using three control stations (Figure 3.6.1). The locations of the control stations were determined during site reconnaissance. Rebar was driven into the ground using a sledge hammer to mark the location of the control stations. In order to determine the coordinates of the control stations, CS1 was assumed to have coordinates of 1000, 1000, $100(\mathrm{X}, \mathrm{Y}, \mathrm{Z})$. CS2 was assumed to lie directly along the Y-axis from CS1. Table 3.4.1 shows the coordinates of the control stations. The $0.1 \mathrm{~m}$ contour lines seen in Figure 3.4.1 show the wetland area has little slope $(<0.20 \mathrm{~m} / \mathrm{m}$. $)$. 
Table 3.4.1. Table of control station coordinates used for the topographic surveying of the Leading Creek Site.

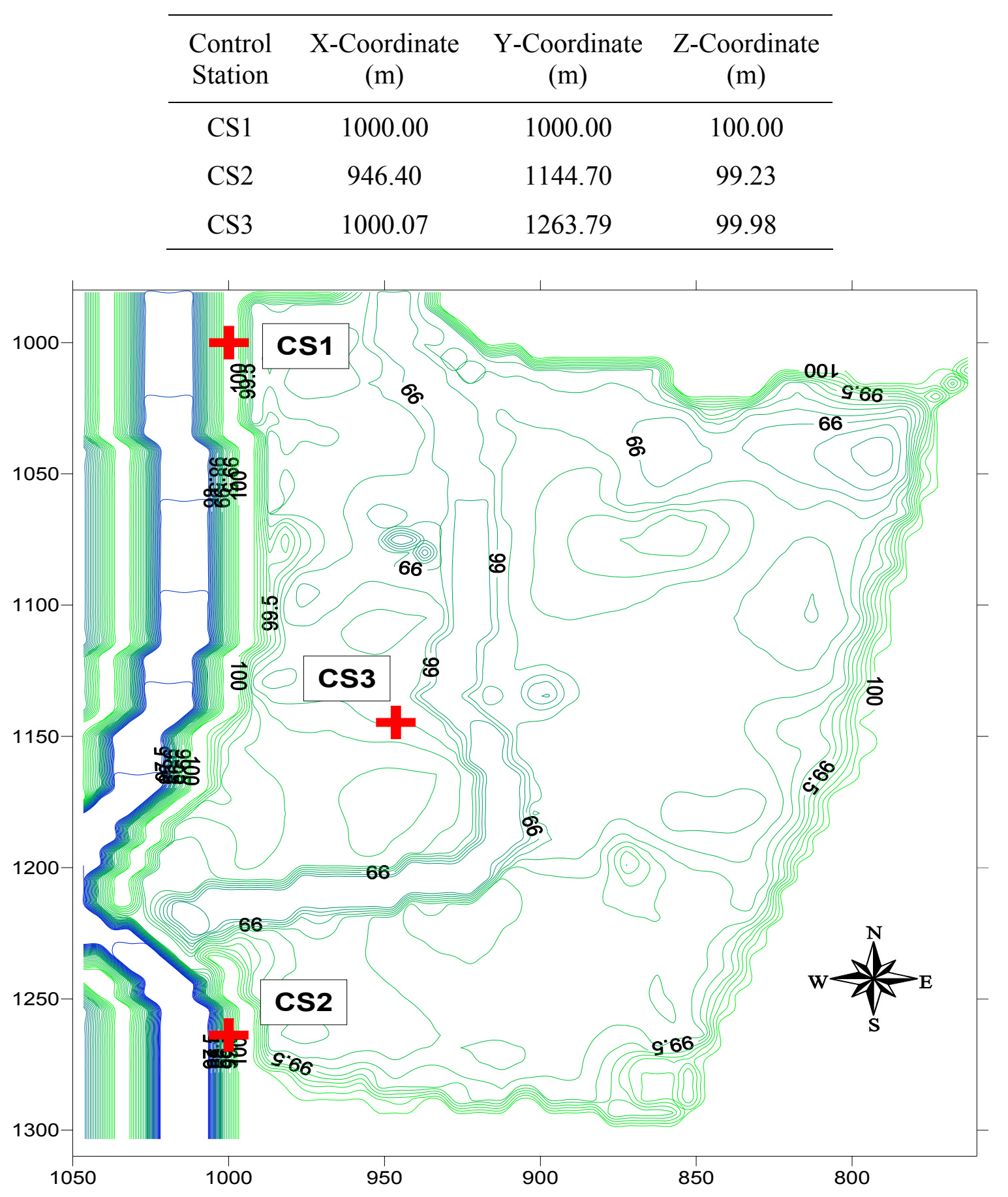

Figure 3.4.1. Topographic map of the Leading Creek study site showing contour lines and control stations. (Contour interval $=0.1 \mathrm{~m}$ ) 


\subsection{METEOROLOGIC DATA COLLECTION}

Meteorologic data from the National Oceanic and Atmospheric Administration's (NOAA) weather station in Elkins, West Virginia $(4304899 \mathrm{~N}, 600190 \mathrm{E}, \mathrm{EL}=603 \mathrm{~m})$, were used to determine net water surface water inputs at the Leading Creek site. Elkins weather data were used because of the station's central location relative to the study sites. These data were downloaded from the NOAA website and input into Microsoft Excel for data reduction. As explained in section 3.8.1, the REF-ET program was used to estimate daily evapotranspiration.

\subsection{COMPUTER PROGAMS}

A variety of computer programs were used to complete this study. Microsoft Excel and Notepad were used for data reduction and interpretation. REF-ET was used to estimate daily evapotranspiration rates. $\operatorname{Surfer}^{\circledR} 8.0$ was used to perform data interpolation and surface gridding. The Department of Defense Groundwater Modeling System version 3.1 (GMS) software package using the FEMWATER groundwater modeling program was used to perform the numerical modeling. These programs are explained in detail in the following sections.

\subsubsection{REF-ET}

To estimate daily evapotranspiration (ET), daily climatic data from the NOAA weather station in Elkins, West Virginia were used in conjunction with REF-ET. REFET calculates reference evapotranspiration using standardized methods recommended in ASCE Manuals and Reports on Engineering Practice No. 70: Evapotranspiration and

Irrigation Water Requirements by Jensen, et al. (1990). The method chosen from the 
fifteen available methods was the "Standardized form of the ASCE Penman-Monteith equation by ASCE 2000" (Allen 2000). The two types of reference ET that can be calculated with this method are short grass and alfalfa. Alfalfa was chosen as the reference ET because it most closely approximated the general height of the vegetation at the wetland sites.

\subsection{2 $\operatorname{Surfer}^{\circledR} 8.0$}

Surfer $^{\circledR}$ is grid based graphing program developed by Golden Software, Inc. (2002). Irregularly spaced XYZ data can be interpolated to a regularly spaced grid using a wide variety of interpolation methods. In addition, the regularly spaced grid files can be easily modified to better represent actual field conditions.

Krigging was the interpolation method chosen to grid the irregularly spaced topographic data to a regularly spaced grid. Krigging is a statistical interpolation method that selects the best linear unbiased estimate of the interpolated parameter. The parameter is assumed to be defined by a variogram, where the variogram is a measure of the change in the parameter with change in distance (Anderson and Woessner 1992).

\subsubsection{GMS}

As described in the User's Manual (BYU 2000), GMS was designed by the Environmental Modeling Research Laboratory of Brigham Young University as a graphical interface for performing a variety of groundwater simulations. Several groundwater modeling programs are available for use in the GMS interface, including MODFLOW, MT3DMS, RT3D, SEAM3D, MODPATH, SEEP2D, FEMWATER, NUFT, and UTCHEM. In addition, a comprehensive set of tools is provided for site characterization, model conceptualization, mesh and grid generation, geostatistics, 
model calibration, and post processing. Further, the program has been designed to allow sharing of data and information between different model types.

Model development is performed in GMS using the provided modules to graphically develop the necessary data files used in the various modeling programs. This can greatly reduce the time and effort spent on entering the data in the necessary files. The available modules are the triangulated irregular network (TIN), borehole, solid, twodimensional (2D) mesh, 2D grid, 2D scatter point, three-dimensional (3D) mesh, 3D grid, 3D scatter point, and map. Detailed descriptions of each of these modules can be found in the GMS Tutorials (BYU 2000). Each of the modules used to perform the groundwater modeling for this study is described in Section 3.9.1.

\subsubsection{FEMWATER}

FEMWATER, which is a three-dimensional, finite-element groundwater model, was developed during the early 1990's by the Athens Laboratory of the U.S. Environmental Protection Agency (AERL) and the U.S. Army Engineer Waterways Experiment Station (WES) as a combined flow and transport groundwater model (Lin et al. 1997). Lin et al (1997) describe the development of FEMWATER as the combining of two older groundwater models. 3DFEMWATER, which was a groundwater flow model, and 3DLEWASTE, which was a groundwater transport model, were combined to produce the present version of FEMWATER. Several improvements were added to FEMWATER during its development, including the restructuring of the program for use in GMS, the addition of a series of new solvers, and the addition of density-driven transport capabilities to model salinity intrusion. FEMWATER was chosen for this study because of its capability to describe flow through saturated and unsaturated porous 
media. A detailed description of the FEMWATER model input is presented in Section 3.7.2.

\subsection{NUMERICAL MODELING}

Numerical modeling was performed using FEMWATER in the GMS interface. In addition to the visual development of the model enabled by the use of GMS, curves defining moisture content, relative conductivity, and water capacity as a function of pressure head in the unsaturated conditions are generated. Described below are the model formulation and parameters used.

\subsubsection{Numerical Model Development}

In order to perform the necessary computations, FEMWATER requires the input of a 3D finite element mesh. Consisting of discretized prismoidal elements, the mesh is an idealized representation of the model domain. For the Leading Creek simulation, a two layer 3D finite element mesh was developed. The top layer of the 3D mesh idealized the conditions of the upper layer of the soil at the site. The bottom layer of the 3D mesh idealized the conditions of the bottom layer of the soil at the site. The development of the 3D mesh using GMS is described below.

A TIN represents a 3D surface by connecting a set of XYZ coordinates with linearly varying edges. TIN files are easily developed using GMS by importing a scatter

point data set. To develop the scatter point data sets, $\operatorname{Surfer}^{\circledR} 8$ was used to interpolate the irregularly spaced topographic data collected at the Leading Creek site to a regularly spaced $10 \times 10 \mathrm{~m}$ grid using krigging. The top of the soil layer scatter point set was developed from the topographic survey data that were collected at the site. The scatter 
point set representing the interface between the two soil layers was developed from information collected during the monitoring device installation. Because the location and elevation of the monitoring devices were surveyed, the elevation of the soil interface was determined by subtracting the depth to the interface, which was found during installation, from the surface elevation. Once the scatter point data sets were imported into GMS, two TINs were constructed (Figures 3.7.1.1a and 3.7.1.1b). The boundaries of these two tins were then modified by deleting unnecessary vertices to better represent the site boundaries, and the grid spacing was modified to increase the size of the elements and reduce simulation time (Figures 3.7.1.2a and 3.9.7.2b). 


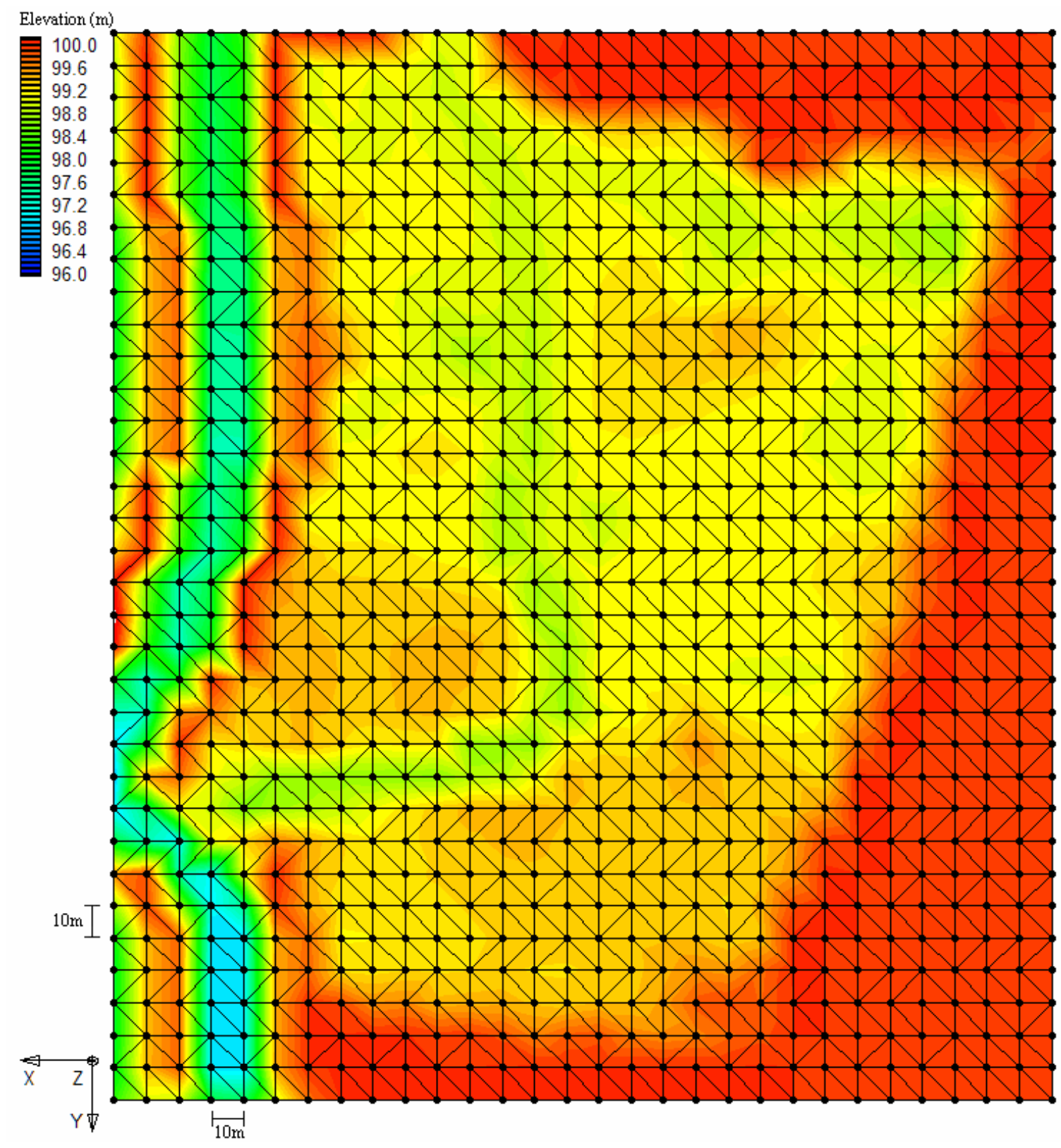

Figure 3.7.1.1a. Figure showing the initial TIN representing the ground surface at the Leading Creek site. 


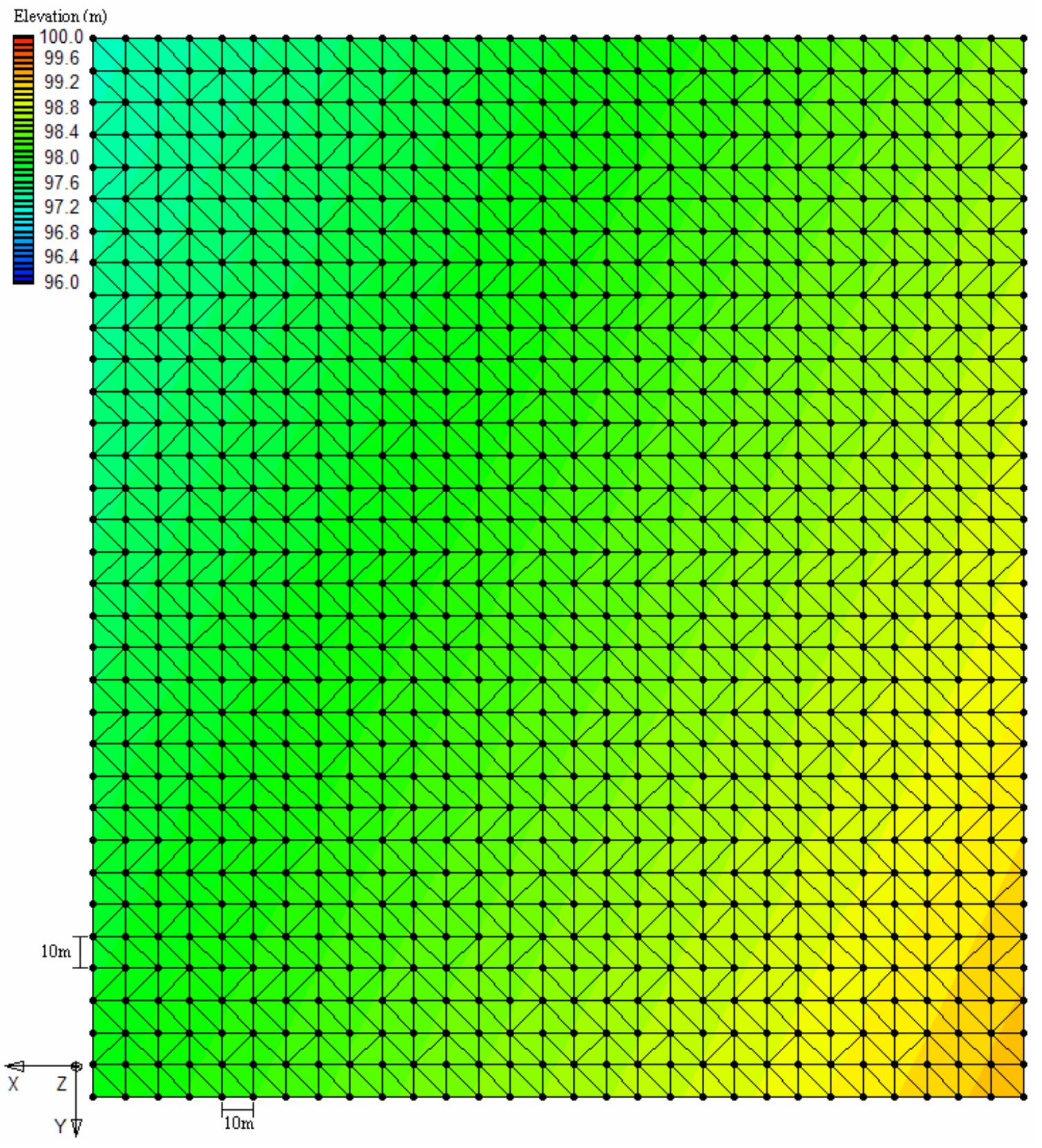

Figure 3.7.1.1b. Figure showing the initial TIN representing the soil interface at the Leading Creek site. 


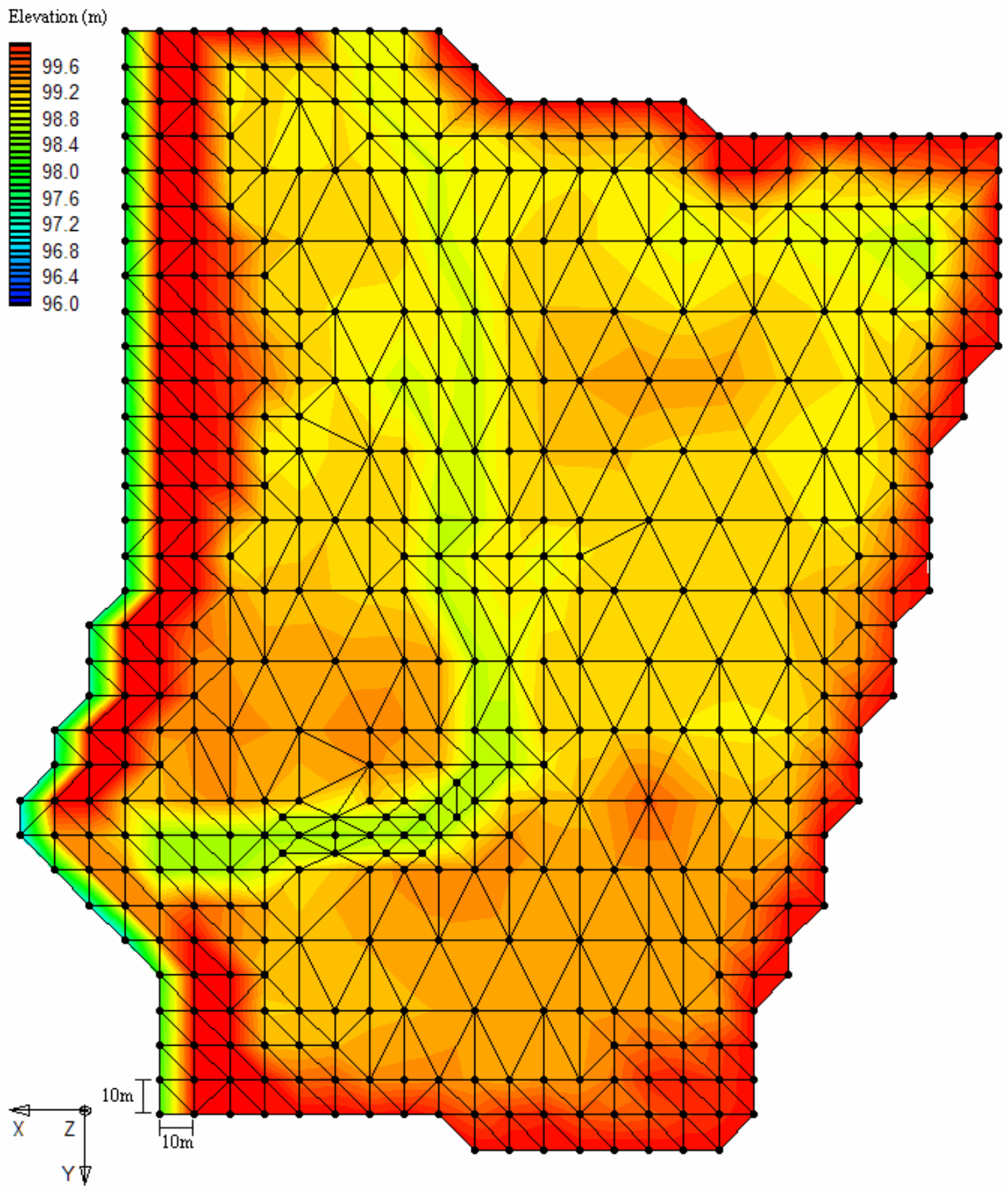

Figure 3.7.1.2a. Figure showing the final TIN representing the ground surface at the Leading Creek site. 


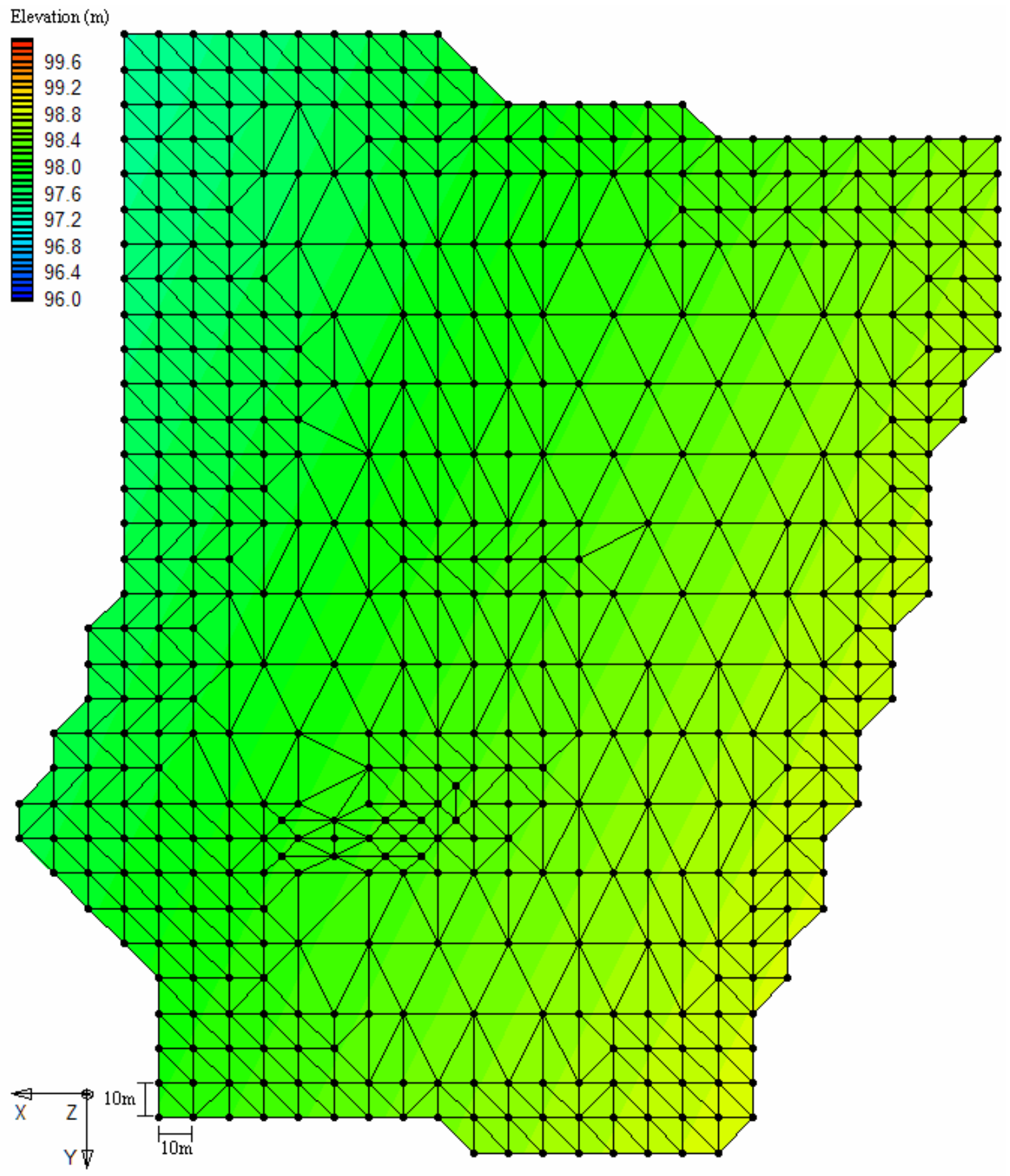

Figure 3.7.1.2b. Figure showing the final TIN representing the soil interface at the Leading Creek site. 
Once the TINs were developed, they were converted to 2D meshes. These 2D meshes are comprised of three node triangular elements, which were then used to develop the 3D mesh. The top layer of the 3D mesh was created by extruding the top 2D mesh to the interface mesh. The bottom 3D mesh was created by extruding the interface 2D mesh downward $1.9 \mathrm{~m}$. Soil properties were assigned to the elements in the 3D mesh based upon field observations and hydraulic conductivity testing results (Table 3.7.1.1). Three different saturated hydraulic conductivities were applied to the top layer of 3D elements. It should be noted that the three materials assigned to the top layer of $3 \mathrm{D}$ elements were all found to have the same texture ( $>60 \%$ clay). The difference in hydraulic conductivity is likely due to the construction technique used on the site. During construction heavy machinery was used for excavation, this machinery most likely compacted a large portion of the site causing an increase in hydraulic conductivity over the majority of the site. One saturated hydraulic conductivity was applied to the bottom layer of elements. Figure 3.7.1.3 shows the simulated 3D mesh and areas where the hydraulic conductivities were applied.

Table 3.7.1.1. Values of simulated saturated hydraulic conductivities.

\begin{tabular}{cccc}
\hline Layer & Material Name & $\begin{array}{c}\text { Vertical Hydraulic } \\
\text { Conductivity } \\
(\mathrm{m} / \mathrm{s})\end{array}$ & $\begin{array}{c}\text { Horizontal Hydraulic } \\
\text { Conductivity } \\
(\mathrm{m} / \mathrm{s})\end{array}$ \\
\hline \multirow{3}{*}{ Upper } & upper1 & $1 \mathrm{E}-08$ & $1 \mathrm{E}-04$ \\
& upper2 & $1 \mathrm{E}-07$ & $1 \mathrm{E}-04$ \\
Lower & upper3 & $1 \mathrm{E}-06$ & $1 \mathrm{E}-03$ \\
\cline { 2 - 4 } & lower & $1 \mathrm{E}-03$ & $1 \mathrm{E}-03$ \\
\hline
\end{tabular}




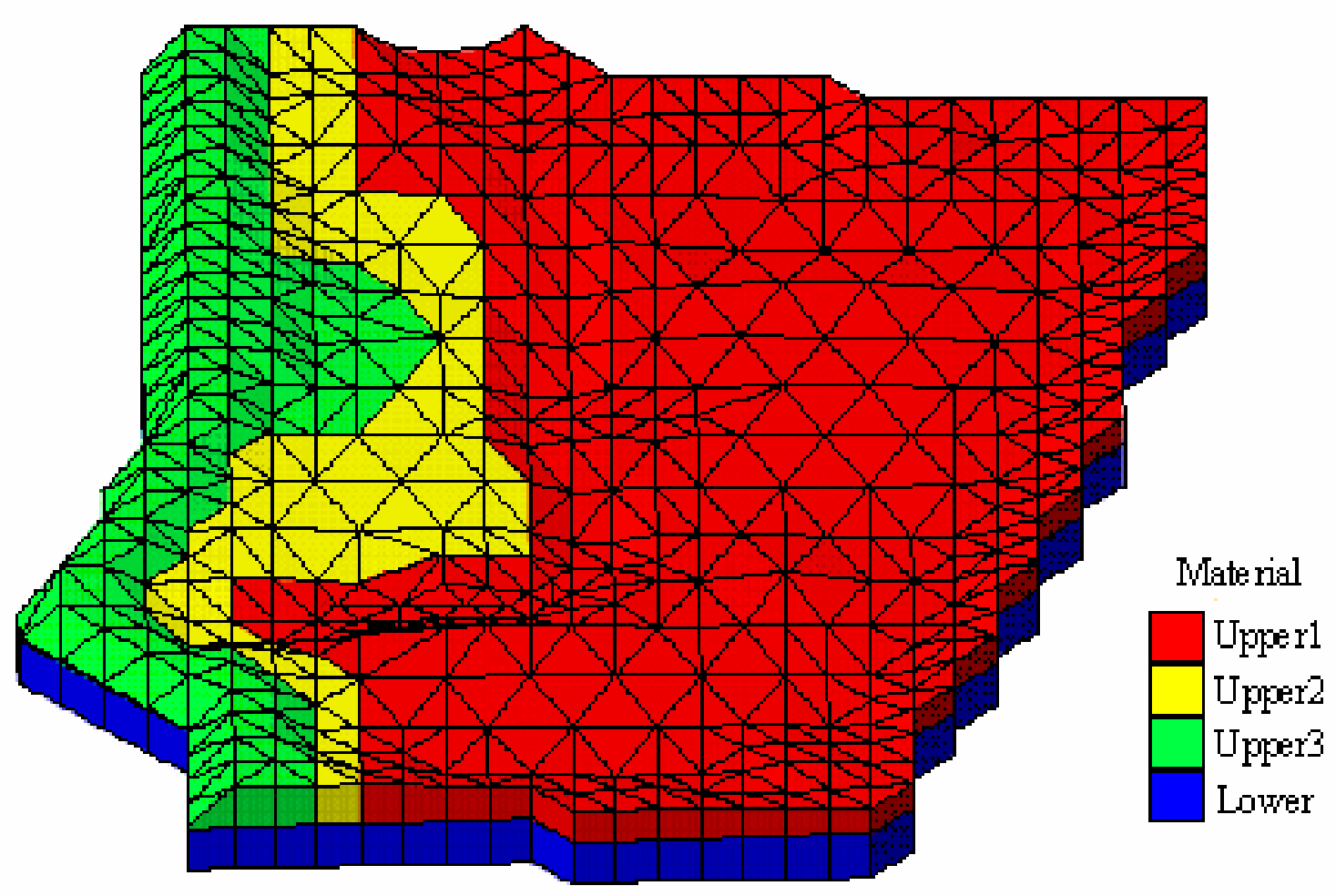

Figure 3.7.1.3. $\quad 3 D$ mesh of the Leading Creek site showing the elements and assigned materials.

In order to describe flow through the unsaturated zones, curves are generated to define volumetric moisture content, relative hydraulic conductivity, and water capacity using the van Genuchten curve generator in GMS. These curves are generated because of the physical phenomena that occur during changing degrees of saturation. Moisture content in the unsaturated zone is a function of pressure head. The more negative the pressure head the lower the moisture content. Hydraulic conductivity in the unsaturated zone can be described by equation 3.7.1.1.

$\mathrm{K}(\mathrm{h})=\mathrm{K}_{\mathrm{r}}(\mathrm{h}) \mathrm{K}_{\mathrm{s}}$

where: $\mathrm{K}(\mathrm{h})=$ hydraulic conductivity, $\mathrm{K}_{\mathrm{r}}(\mathrm{h})=$ relative conductivity, and $\mathrm{K}_{\mathrm{s}}=$ saturated conductivity 
The change of relative conductivity is caused by changes in moisture content, which result in the preferential movement of water through certain pathways because of capillary forces. As the soil becomes less saturated, pores with larger diameters dry first because of smaller capillary forces. Therefore, flow is restricted to pores with smaller diameters. This results in a reduction of effective hydraulic conductivity. Water capacity is defined as the slope of the moisture content versus pressure head curve (Lin et al. 1997).

The generation of the curves requires the input of the maximum height of the soil above the water table and the soil composition (clay, silt, loam, etc.). The maximum height above the water table for the upper layer of soil was entered as $1.5 \mathrm{~m}$. This value was based on the measured depth to the water table and field observations. A value of 0 $\mathrm{m}$ was used for the bottom layer since the water table was not observed to fall below the top of this layer. The 3 materials used in the top layer of soil were all defined as $60 \%$ clay based on the collected soil samples. The bottom layer of soil was defined as sand because this was the largest grain size available from the selection of materials in the curve generator. The values of the curves are defined as a function of pressure head. When the pressure head is $\geq 0$ saturated values are used. When the pressure head is $\leq 0$ the curve values are used. Table 3.7.1.2 shows the input parameters used to determine the curves for each of the simulated materials. Figure 3.7.1.4 shows typical curves generated by GMS.

Inspection of Figure 3.7.1.4 shows the water capacity declines sharply as the pressure head approaches zero. Even though it appears as though the water content is defined by a linear curve, detailed review of the data shows that the slope does 
decrease as the pressure head approaches zero.

Additionally, porosity is equal to the water content when the soil is fully saturated. Soil porosity is assumed by the model based on the curve generator's estimates of fully saturated water content. The storage coefficient is calculated by FEMWATER as a function of the soil compressibility, water content, and saturation, compressibility of water, and pressure head.

Table 3.7.1.2. Tabulated input parameters used to generate the unsaturated moisture content, relative conductivity, and water capacity for each of the simulated materials.

\begin{tabular}{cccc}
\hline Layer & Material Name & $\begin{array}{c}\text { Max. height above } \\
\text { water table }(\mathrm{m})\end{array}$ & Material type \\
\hline \multirow{3}{*}{ Upper } & ground1 & 1.5 & Clay $(60 \%)$ \\
& ground2 & 1.5 & Clay (60\%) \\
& ground3 & 1.5 & Clay (60\%) \\
\cline { 2 - 4 } Lower & lower & 0.0 & Sand \\
\hline
\end{tabular}




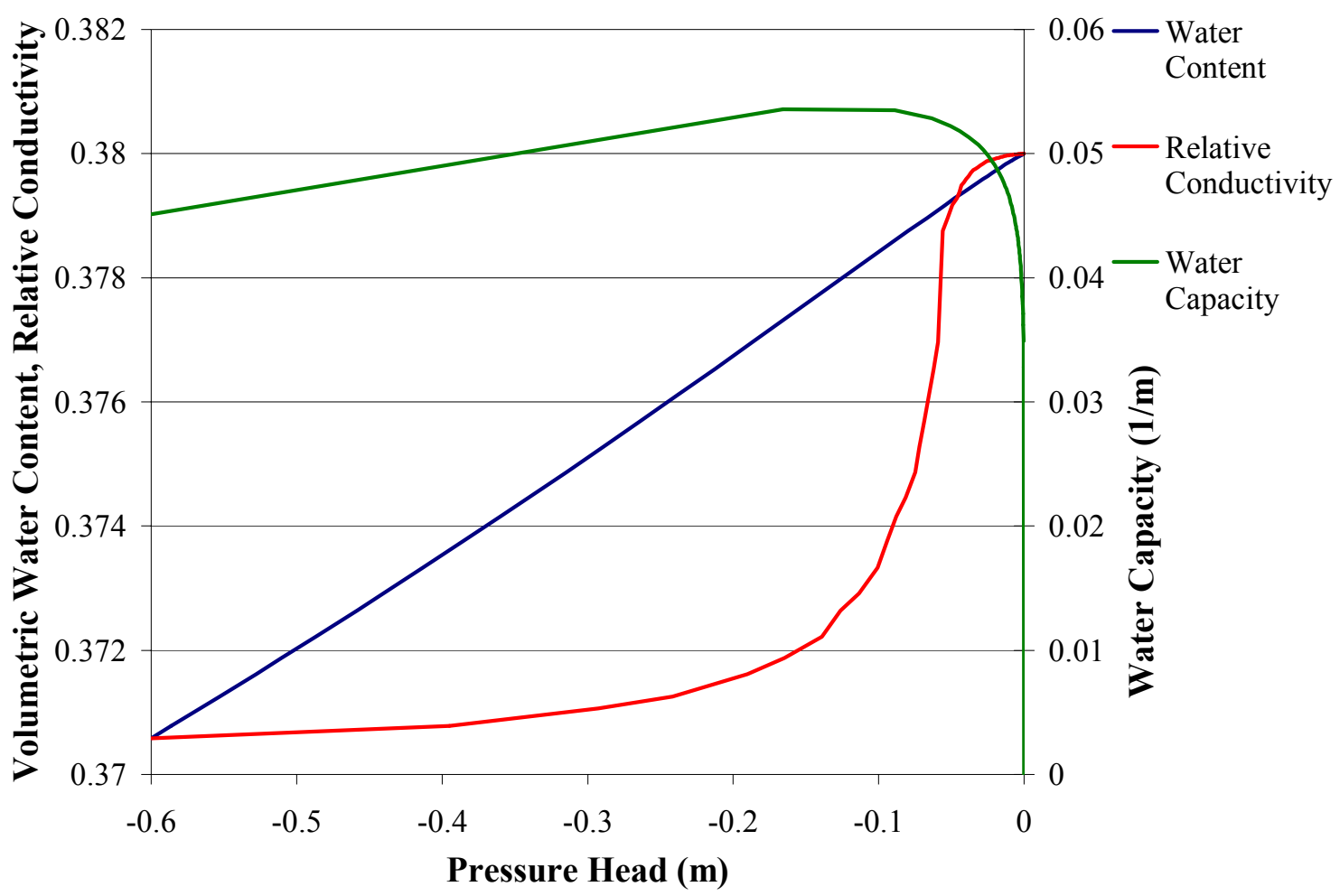

Figure 3.7.1.4. Generated curves in the upper layer for water content, relative conductivity, and water capacity in the unsaturated zone using the van Genuchten Curve generator in GMS.

Following the development of the $3 \mathrm{D}$ mesh, boundary conditions were applied to the model. Three types of boundary conditions were used in the simulation, including constant head, variable flux, and variable. Constant head boundary conditions were applied to the perimeter of the site and to the perimeter of the ponded area in the northeast portion of the site (Figure 3.7.1.5). Variable flux boundary conditions, which represent rainfall and evapotranspiration, were applied to the top face of all the elements in the upper layer of the 3D mesh. The use of variable flux boundary conditions also required that the maximum allowable ponding depth and minimum allowable pressure head be entered. These values are defined in GMS as the variable boundary conditions. The use of these conditions allows the model to change from a flux condition to a 
Dirichlet (constant head) condition. When the depth of water on the surface reaches the maximum ponding value, the node is changed from a flux to a constant head value. Similarly, when the pressure head falls to the minimum value, the node is changed from a flux condition to a constant head condition. A value of $0.30 \mathrm{~m}$ was used for the maximum ponding. This value was determined from field observations at the site. The minimum pressure head was set to $-1.5 \mathrm{~m}$. This value was controlled by the maximum difference between the ground surface elevation and the water table, which was located in the southwestern corner of the site. 


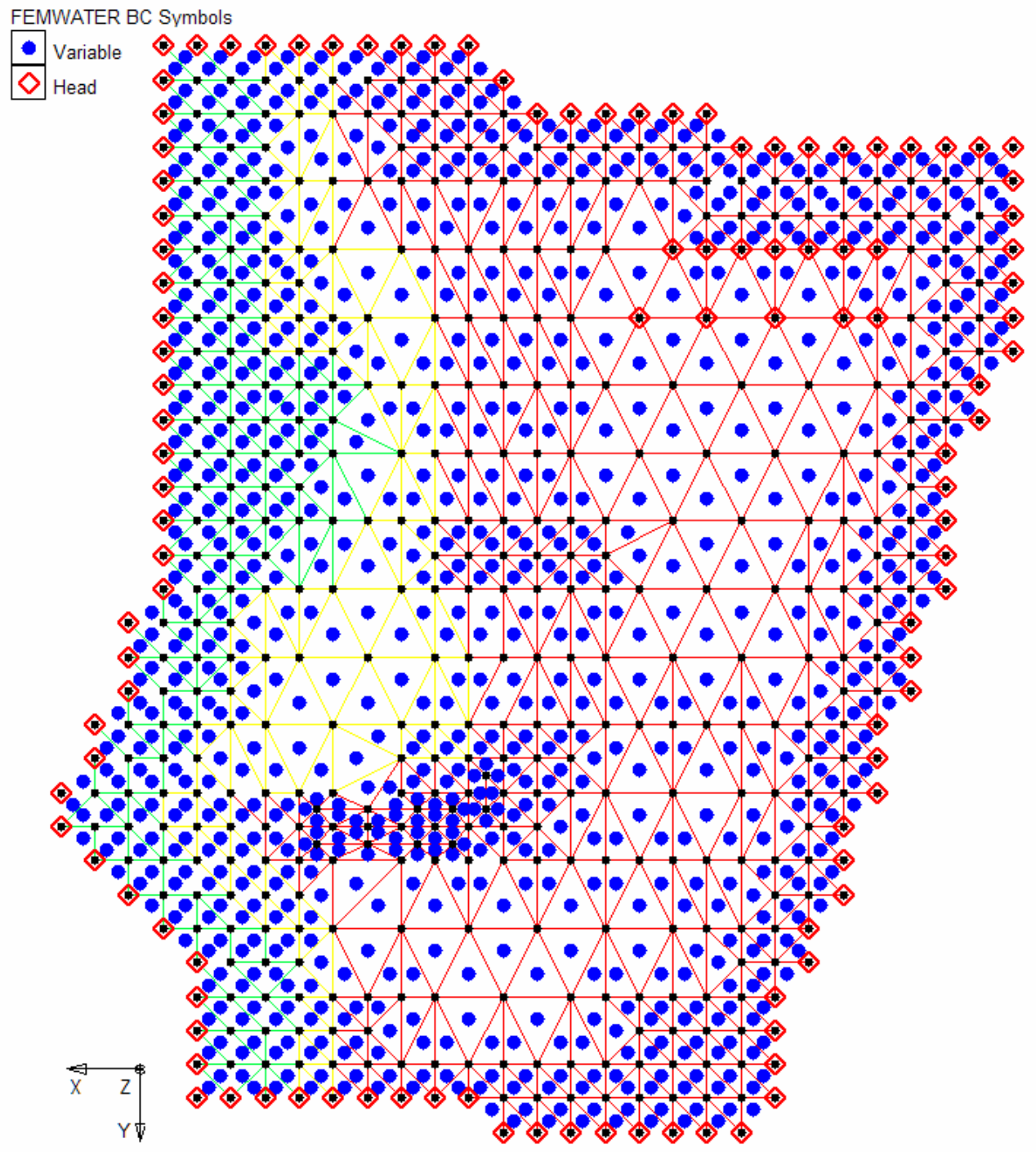

Figure 3.7.1.5. 3D mesh of the Leading Creek site showing boundary condition assignments.

\subsubsection{Run Options}

Several run options had to be selected for the numerical model simulation. These options include the quadrature selection, weighting factor, mass lumping, simulation type, relaxation parameter for nonlinear flow, relaxation parameter for linearized flow, solver selection, time control, and iteration parameters. 


\subsubsection{Quadrature Selection}

Lin et al. (1997) state the quadrature selection parameter indicates the type of quadrature used in the numerical integration of the flow equations. The gaussian/gaussian quadrature was selected for the simulation because it yields the most accurate results. This selection allows gaussian quadrature to be used for both surface and element integration. The use of gaussian quadrature allows for a higher order integration to be used in solving the numerical equations used to perform the simulations (DeVries, 1994).

\subsubsection{Weighting Factor}

The weighting factor (WF) determines how the time derivative terms associated with the velocity term in the flow equations are evaluated (Lin et al., 1997). According to Lin et al. (1997), WF should equal one for most practical problems; therefore this value was used for the simulation. This allows the time derivatives to be evaluated only at the new time step.

\subsubsection{Mass Lumping}

Mass lumping reduces the mass matrix to the finite-difference equivalent at the element nodes (Lin et al., 1997). Although the use of mass lumping will reduce the accuracy of the solution, it will increase the simulation stability. Mass lumping was used in the simulation as Lin et al. (1997) recommend for saturated-unsaturated flow simulations.

\subsubsection{Simulation Type}

Two types of simulations (steady-state and transient) were used for the study. A steady-state simulation was performed to develop the initial head values for the transient simulation. A transient simulation was used to determine a time dependent solution for the 
study period. Section 3.9.2.8 explains the time control parameters used for the transient simulation.

\subsubsection{Relaxation Parameter for Nonlinear Flow (OMEF)}

According to Lin et al. (1997), when flow equations are nonlinear, the pressure head needs to be estimated to form the matrix equation. Three options are available for estimating this value: underrelaxation $(0<\mathrm{OMEF}<1)$, exact $(\mathrm{OMEF}=1)$, and overrelaxation $(1<$ OMEF $<2$ ). The OMEF value is a weighting factor that is applied to newly obtained values of

pressure head, and a weighting factor of $(1-\mathrm{OMEF})$ is applied to the previous guesses of the pressure head values. An OMEF value of 1 should normally be used, but an oscillating pattern of convergence developed during the simulations. As recommended by Lin et al. (1997), the OMEF value was changed to 0.5 to eliminate the oscillations.

\subsubsection{Relaxation Parameter for Linearized Flow (OMIF)}

Lin et al. (1997) state that in order for the linearized matrix equations to be solved using the iteration method, an estimate of the solution is needed before the next iteration can be performed. Three options are available to estimate the solution based on previous guesses and the newly obtained solution. These options are similar to the ones available for the OMEF. As with the OMEF, a value of OMIF $=1$ should typically be used. But the OMIF value was changed to 0.5 after the oscillating pattern of convergence was identified.

\subsubsection{Solver Selection}

The pointwise iterative matrix solver was used to develop the solution to the numeric model. This is the most robust and most commonly preferred of the solvers available in FEMWATER (Lin et al., 1997). Lin et al. (1997) recommend the use of this solver unless the convergence speed is too slow. 


\subsubsection{Shape Functions}

Shape functions are used to define how a parameter varies between nodes in a finite element model. The shape functions can be either linear or non-linear. FEMWATER only allows for linear shape functions. Because FEMWATER uses a linear shape function multiple layers should ideally be used to gain better vertical resolution and a more accurate solution to actual conditions.

\subsubsection{Time Control}

The time control options determine the maximum simulation time and the length and the type of time steps. In addition, the reference time is set through the time control. Because the model was run individually for each month of the study, the maximum simulation time varied from 27 days to 30 days depending on the month. The first day of each month is taken to be day zero; therefore, the maximum simulation time is equal to the total number of days in the simulated month minus one. A constant time step of one day was used for all of the simulations. Therefore, a solution was developed for every day of the study period. The reference time was set to the 12:00 p.m. on the first day of each month.

\subsubsection{Iteration Parameters}

Iteration parameters included maximum iterations for non-linear equations (50), maximum cycles per time step for variable boundary conditions (5), maximum iterations for linear equations (500), steady-state convergence criterion $(0.01 \mathrm{~m})$, and transient convergence criterion $(0.01 \mathrm{~m})$. Convergence criteria were used to set the maximum change allowed between each iteration of the flow equations. For each time step, the model would solve the flow equations and determine the difference in values between the current and previous iteration. If the maximum change was less than or equal to the defined maximum, the 
model would then go to the next time step. If the maximum change was greater than the defined maximum, the model would continue to solve the equations until the criteria was satisfied. In the case that the maximum number of iterations was reached, the model would reevaluate the variable boundary conditions. If the maximum number of cycles for the variable boundary conditions was violated, the model was not convergent and would go to the next time step. Full convergence occurred in the final version of the model.

\subsubsection{Model Calibration}

The first step in calibrating the numerical model was to develop a steady state solution. Because no long-term data were collected at the constant head boundaries, these boundary conditions did not vary for the duration of the simulation. The steady state solution was developed to satisfy the statistical mode of the monitoring device data. Constant head elevations were determined for the western side by measuring the elevation of the normal water depth in Leading Creek. The eastern constant head elevations were determined by extending the statistical mode of the groundwater levels to the model boundary by extrapolating the surface boundary using the slope of the groundwater table. The northern and southern boundaries were determined by linearly interpolating between the corner constant head elevations found for the western and eastern sides of the site. To develop the required solution, the constant head boundary conditions were modified until the root mean square (RMS), using equation 3.9.3.1, of the statistical mode of the collected monitoring device data and the model solution was less than $0.15 \mathrm{~m}$. Once the RMS criteria were satisfied, the steady state solution was used as the initial condition for the January 2001 transient solution. Starting with February 2001 the pressure heads calculated for the last day of the previous month was used as the initial condition for that month's solution. 
$\mathrm{RMS}=\sqrt{\frac{\sum_{\mathrm{i}=1}^{\mathrm{n}}\left(\mathrm{y}_{\mathrm{f}}-\mathrm{y}_{\mathrm{m}}\right)^{2}}{\mathrm{n}}}$

where: $\mathrm{RMS}=$ root mean square, $\mathrm{y}_{\mathrm{f}}=$ field value, $\mathrm{y}_{\mathrm{m}}=$ model value, and $\mathrm{n}=$ number of measurements

The transient model was run from January 1, 2001 through May 31, 2002. RMS values were calculated on the days data had been collected at the site. As with the steady state model, a target RMS value of $0.15 \mathrm{~m}$ was chosen. After the model was run, the RMS values were inspected. Adjustments were then made to the constant head boundary conditions to better satisfy the field data values. This process was repeated until the RMS values were within an acceptable range. 


\section{CHAPTER 4.0 RESULTS}

\subsection{WETLAND HYDROLOGY}

Water levels in all of the monitoring devices at the sites followed seasonal patterns. In general, water levels were closest to the ground during the winter and spring months (January to April) when evapotranspiration was minimal. Water levels decreased during the summer and fall because of increased evapotranspiration. Figures 4.1.1 through 4.1.4 show graphical results of the collected groundwater level data. Tabulated results are present in Tables A.1 through A.5.

Groundwater levels were found to increase in depth below the ground surface closest to the stream, throughout the entire study period, at all of the sites with the exception of LC7 and SC4. LC7 was located in the northeastern corner of Leading Creek next to a large area of persistent standing water. Surface water from a culvert flowed into this area from a roadside ditch along US Route 219. SC4 was located in a depression area adjacent to Sugar Creek. This area was fully saturated during each field visit, presumably from direct contact with the groundwater table.

No data is shown for three of the devices shown in the monitoring plan for the western portion of the Leading Creek site (Figure 3.2.5.1). Damage occurred to LC-P2 at some time during the monitoring period; therefore none of the collected data were used to avoid presenting erroneous data. LC-P4 was installed in a very wet area and sunk into the ground after the second month of reading. LC-R1 experienced several electrical failures causing the loss of substantial data. 

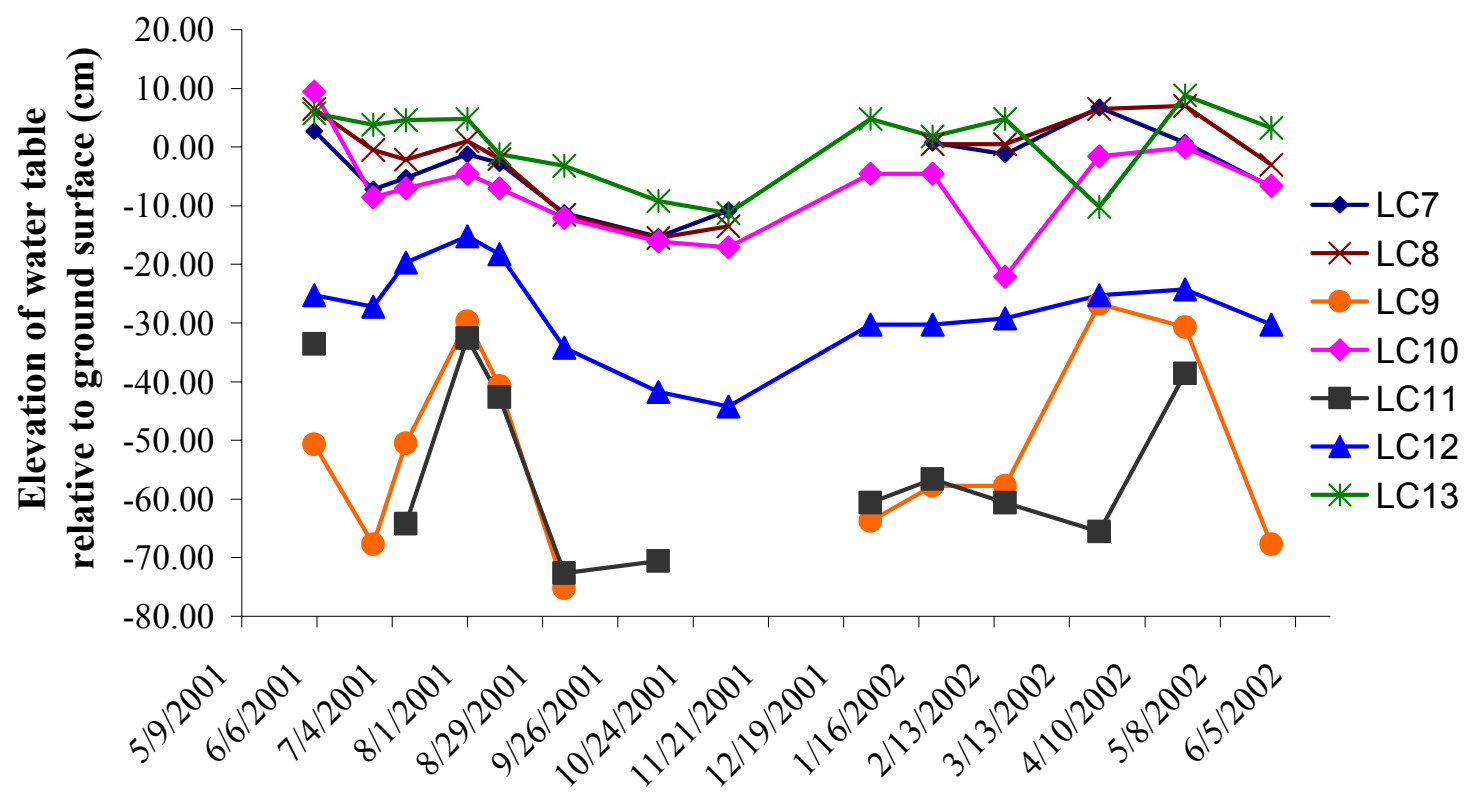

Date of Measurement

Figure 4.1.1. Water level elevations relative to the ground surface at the eastern side of the Leading Creek site. (Ground level = 0 )

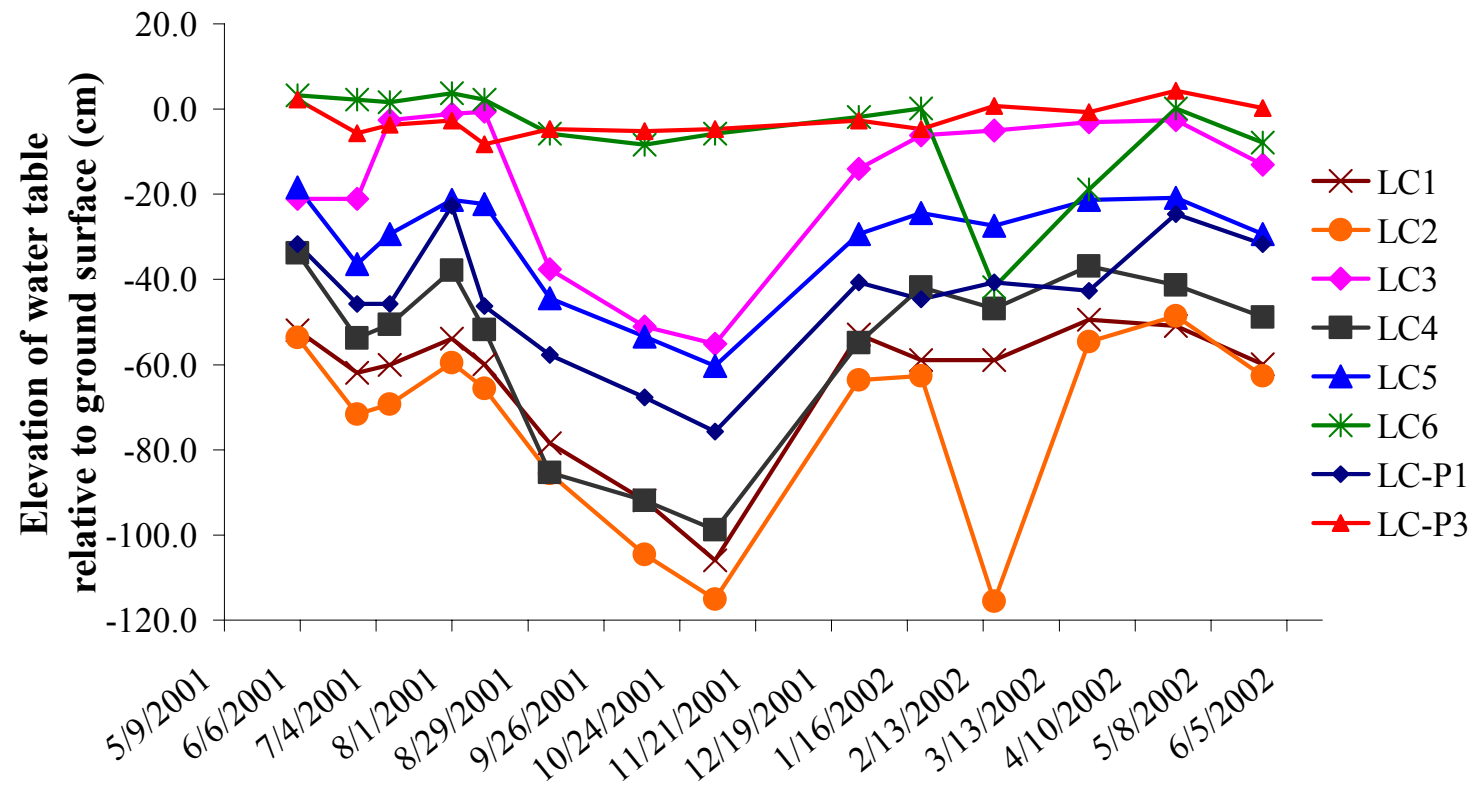

Date of Measurement

Figure 4.1.2. Water level elevations relative to the ground surface at the western side of the Leading Creek site. (Ground level $=0$ ) 

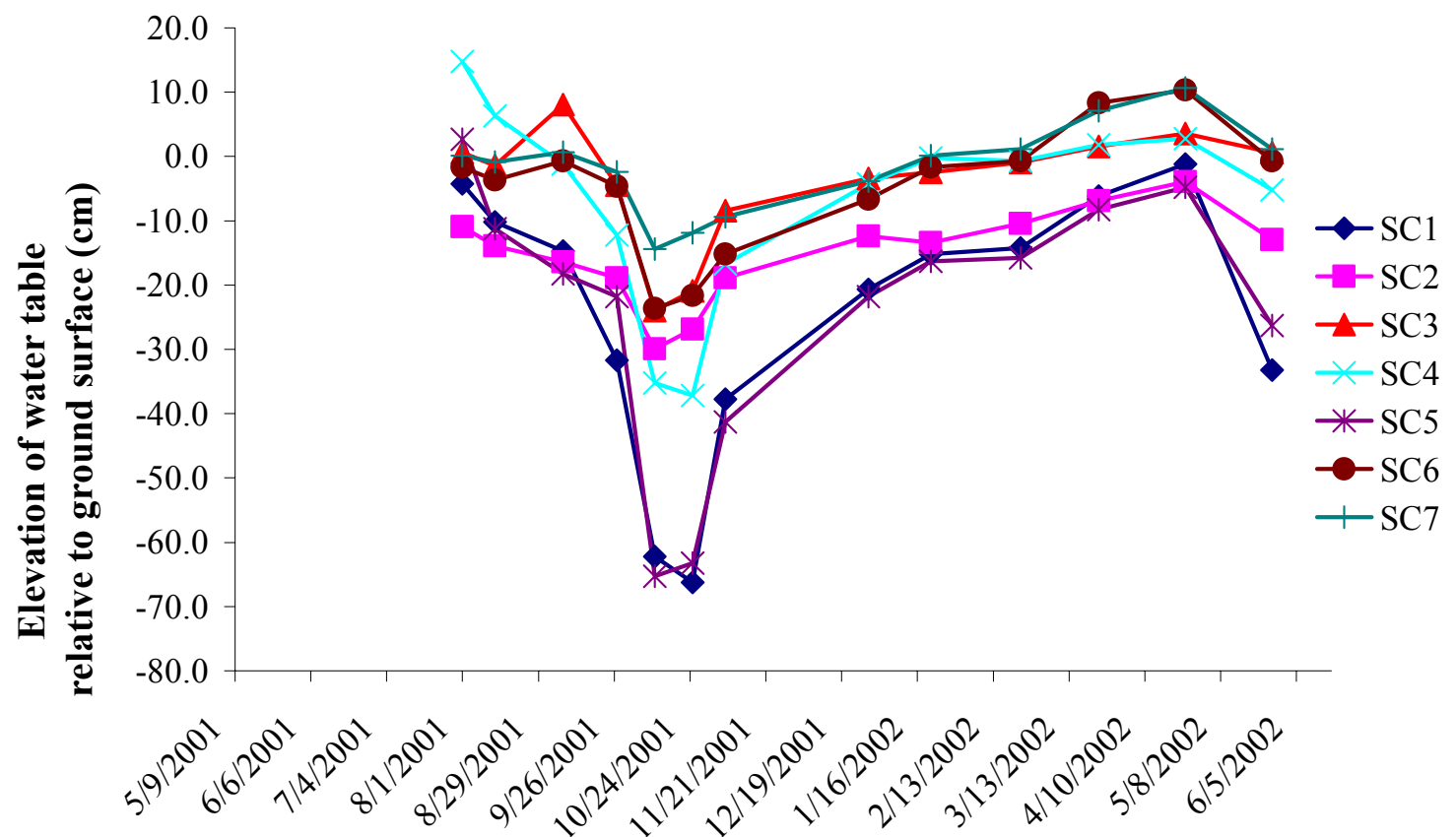

Date of Measurement

Figure 4.1.3. Water level elevations relative to the ground surface at the Sugar Creek site. (Ground level $=0$ )

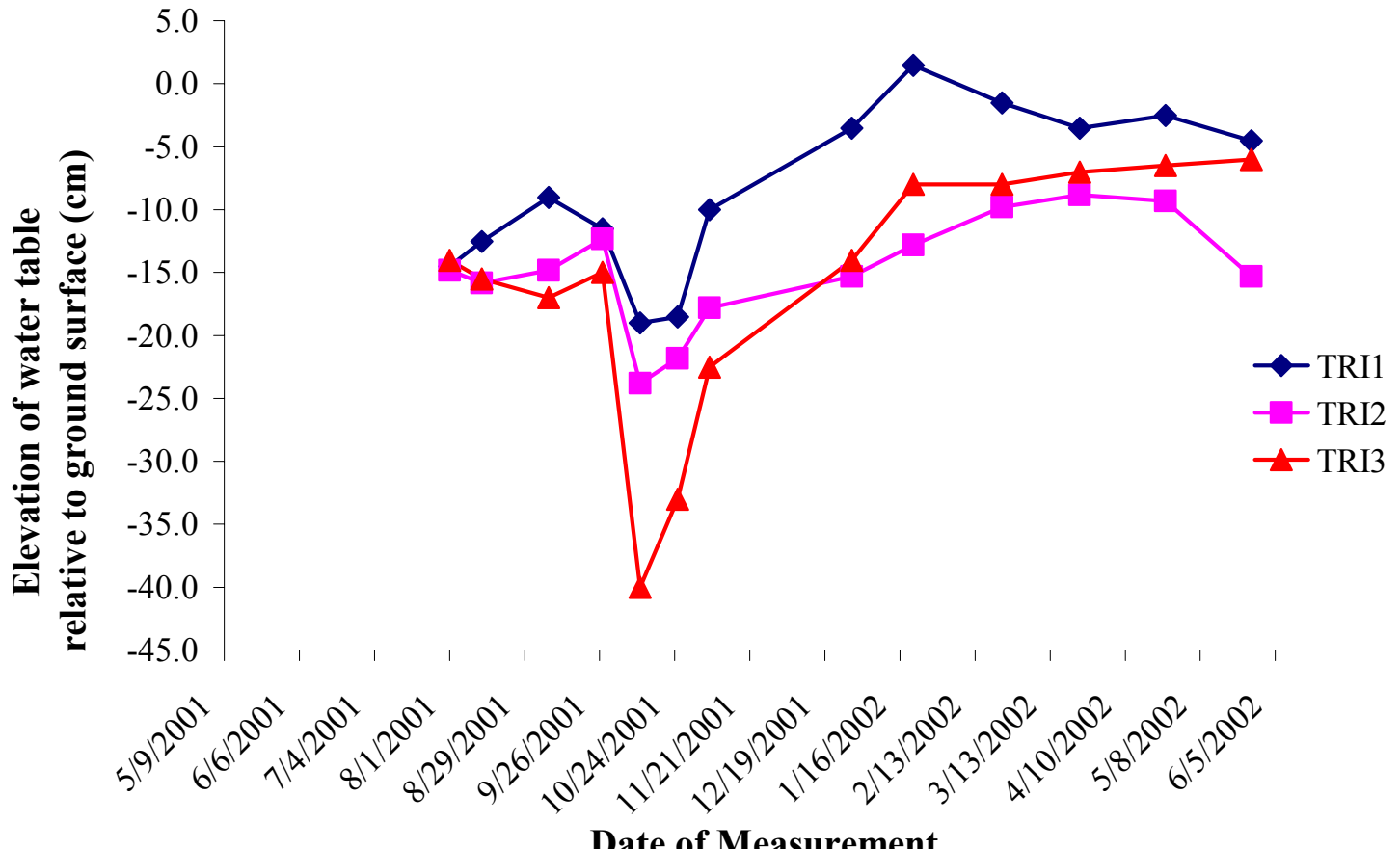

Figure 4.1.4. Water level elevations relative to the ground surface at the Triangle site. $($ Ground level $=0$ ) 

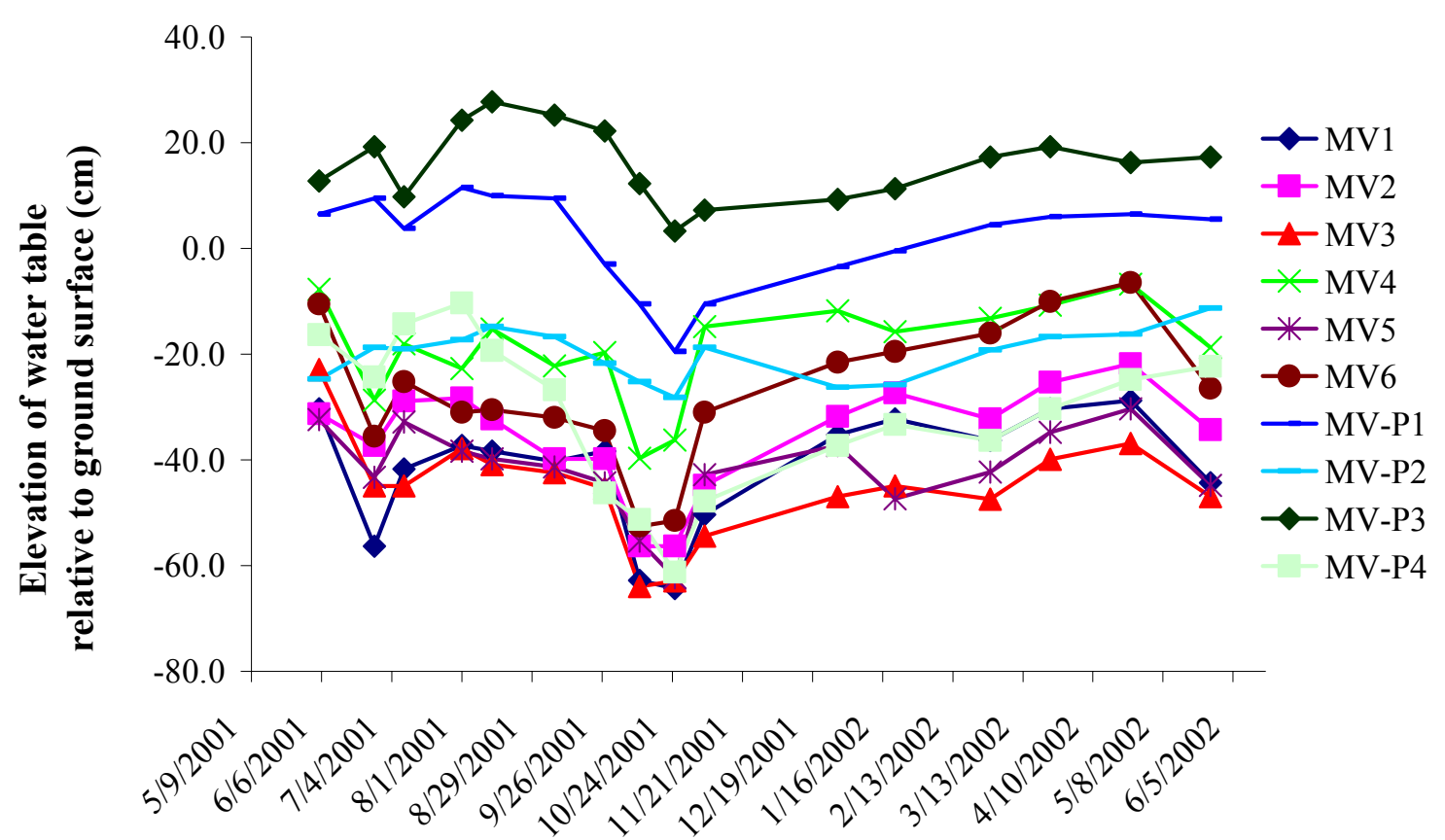

Date of Measurement

Figure 4.1.5. Water level elevations relative to the ground surface at the Meadowville site. (Ground level $=0$ )

Investigation of United States Geological Survey (USGS) topographic maps, design plans, and measured topographic data showed that all of the valleys in which the studied wetland sites occur slope from the toe of the slope towards the stream. Because of these negative valley slopes toward the stream and the increase in depth to the groundwater table closest to the stream, all of the streams were found to be gaining groundwater. Therefore, large amounts of groundwater are passing through the wetland sites.

\subsection{SITE COMPARISONS}

\subsubsection{Mean Depth to Water Table}

Comparison of the mean depth to the water table at each well during the study period showed that water levels in most of the wells at the constructed mitigation 
wetlands were within the range of values found at the natural reference wetland (Figure 4.2.1.1). Tabulated values are presented in Table A.6. The maximum average depth to the ground water table found at the reference wetland was $-0.45 \mathrm{~m}$, where (-) indicates levels below the ground surface. Five wells, all of which were located in the Leading Creek study site, were found to have an average depth to the ground water table $<-0.45$ m. Monitoring wells LC1, LC2, LC4, LC9, and LC11 had average values of $-0.64,-0.74$, $-0.55,-0.52$, and $-0.54 \mathrm{~m}$, respectively. During a concurrent study (Balcombe 2003), areas around these wells, with the exception of LC4, were classified as upland habitat, as expected. The only other well found to be upland habitat by Balcombe (2003) was LCP1, which had a value of $-0.44 \mathrm{~m}$.

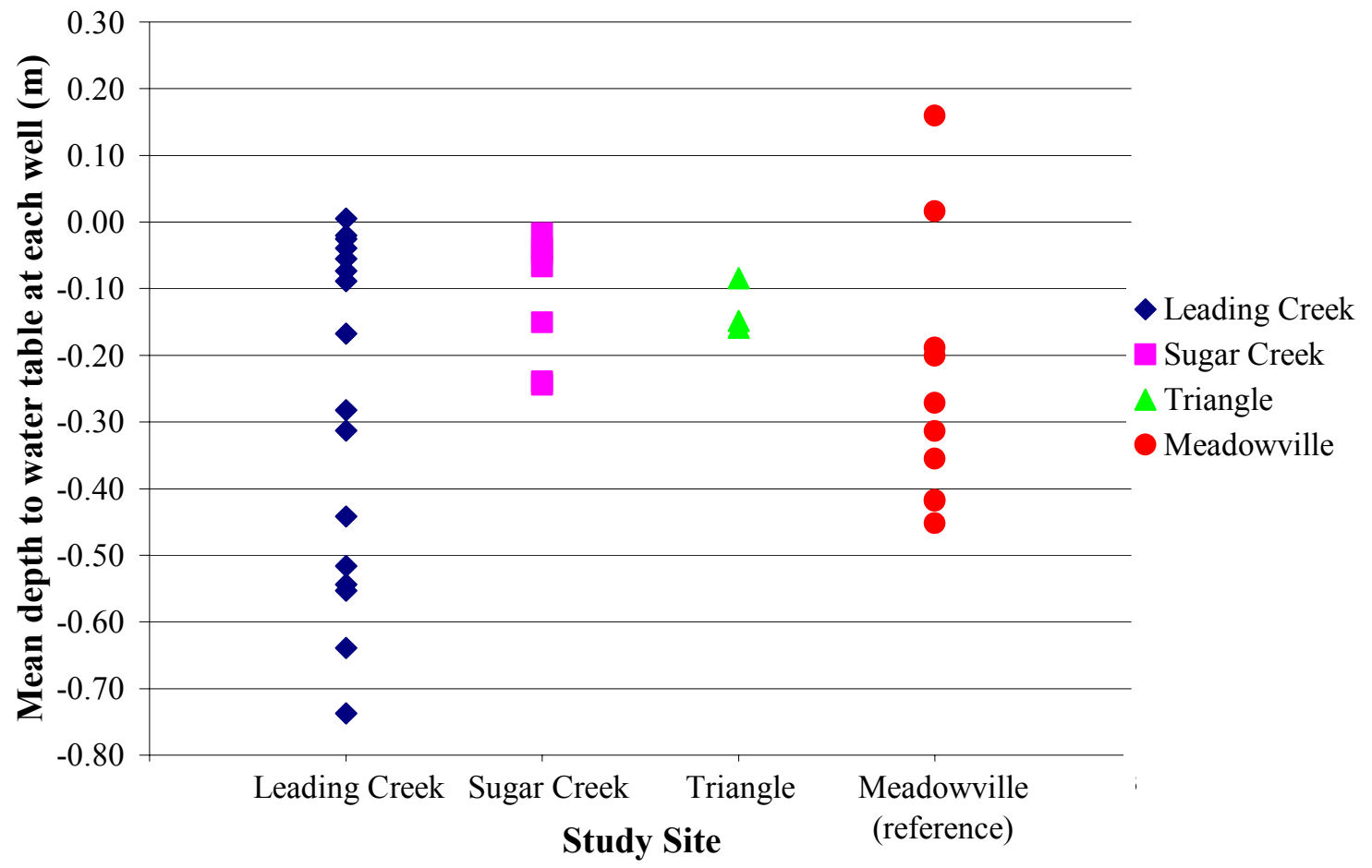

Figure 4.2.1.1. Graph of mean depth to water table for each well at the study sites. $($ Ground level $=0$ ) 


\subsubsection{Standard Deviation of Depth to Water Table}

The measurement of standard deviation of the depth to the water table describes the persistence of water sources available at that location. Large values of standard deviation indicate that depth to the water table undergoes large variations. Precipitation, which does not occur continually, provides water input in an unpredictable manner. Conversely, groundwater levels remain relatively constant for long periods of time.

Comparison of the standard deviation of depth to the water table showed values at most of wells in the constructed mitigation wetlands were within the range of values found at the natural reference wetland (Figure 4.2.2.1). Tabulated values are presented in Table A.6. The maximum standard deviation of the depth to the water table found at the reference wetland was $0.15 \mathrm{~m}$. Six wells were found to have to have a standard deviation $>0.15 \mathrm{~m}$. Monitoring wells LC1, LC2, LC3, LC4, LC9, SC1, and SC5 had standard deviations of 0.17, $0.23,0.19,0.21,0.16,0.21$, and $0.21 \mathrm{~m}$, respectively.

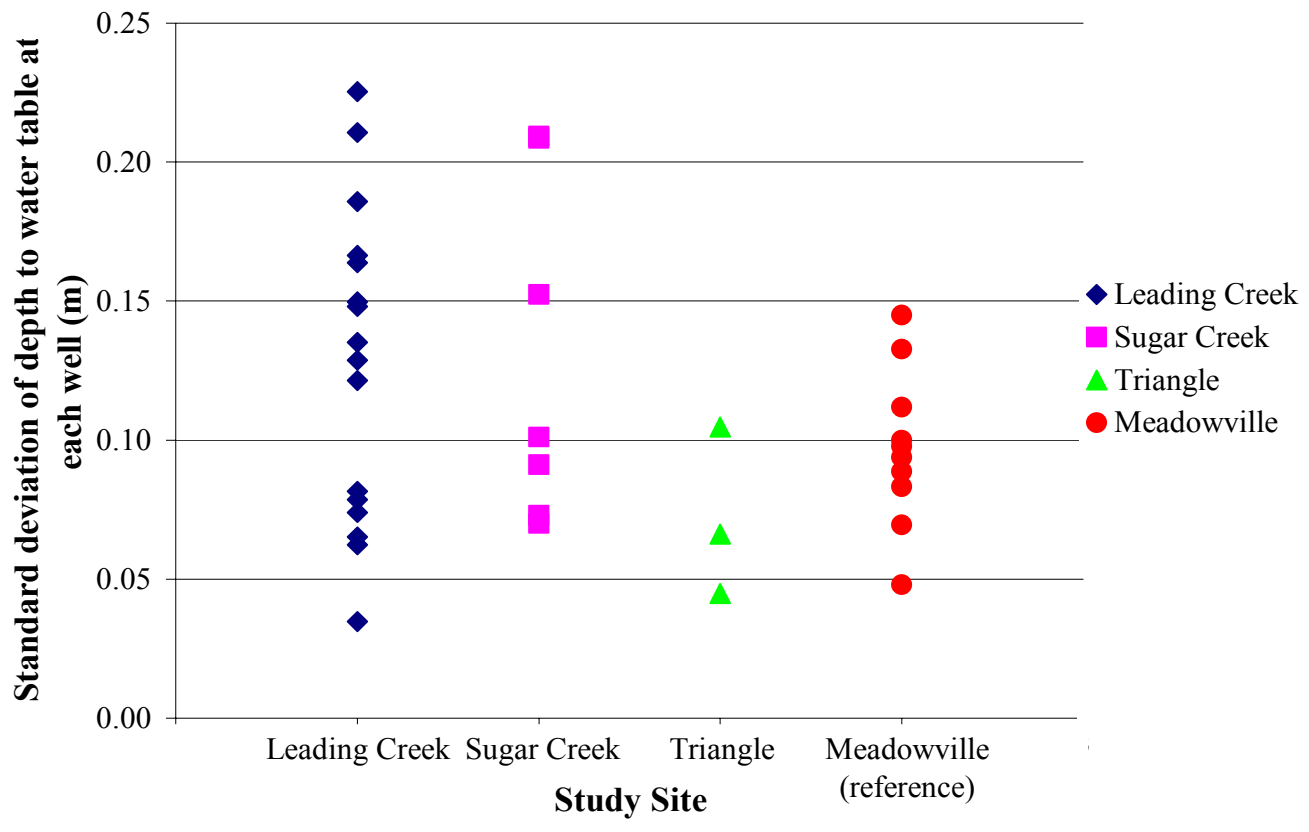

Figure 4.2.1.1. Graph of standard deviation to depth of water table for each well at the study sites. (Ground level $=0$ ) 
Balcombe (2003) classified areas around monitoring wells LC1, LC2, and LC9 to be upland habitat and areas around monitoring wells LC3, LC4, SC1, and SC5 to be wetland habitat (Balcombe 2003). The importance of this is to recognize that of the 21 devices located in wetland habitat $16(76 \%)$ are located in areas with persistent sources of water.

\subsection{LEADING CREEK HYDROLOGIC MODELING}

\subsubsection{Model Calibration}

Tabulated root mean square (RMS) differences between simulated head values and the field head values, which were calculated using Equation 3.9.3.1, are presented in Table 4.3.1.1. An RMS value $\leq 0.15 \mathrm{~m}$, which was the target calibration value, was achieved for 10 of the 14 days that field data were collected. The maximum RMS values occurred on June 27, 2001, and March 24, 2002, each of which had values of $0.17 \mathrm{~m}$. On each of the days where the RMS value was higher than the target value, one well had a difference between the field measurement and model value that was much larger than the rest of the wells. On two of these four occasions LC9 was larger. LC11 and LC13 were each much larger on one of the other two occasions when the RMS target value was not achieved. While the exact cause of these discrepancies is not known, it should be noted that LC9 and LC11, which were located in upland habitat, were found to be two of the most variable wells at any of the study sites. Because constant head boundary conditions were used for the duration of the simulation, LC13, which is located close to the southeastern corner of the site, showed little variation. 


\section{Table 4.3.1.1. Daily RMS differences between the hydrologic model head values simulated for the Leading Creek study site and observed field values.}

\begin{tabular}{cc}
\hline Date & RMS (m) \\
\hline $6 / 5 / 2001$ & 0.12 \\
$6 / 27 / 2001$ & 0.17 \\
$7 / 9 / 2001$ & 0.09 \\
$8 / 1 / 2001$ & 0.11 \\
$8 / 13 / 2001$ & 0.14 \\
$9 / 6 / 2001$ & 0.16 \\
$10 / 11 / 2001$ & 0.15 \\
$11 / 6 / 2001$ & 0.13 \\
$12 / 29 / 2001$ & 0.15 \\
$1 / 21 / 2001$ & 0.15 \\
$2 / 17 / 2001$ & 0.12 \\
$3 / 24 / 2001$ & 0.17 \\
$4 / 25 / 2001$ & 0.16 \\
$5 / 27 / 2001$ & 0.15 \\
\hline
\end{tabular}

\subsubsection{Leading Creek Model Results}

Results of the ground water model show wetland conditions present at the site are highly dependent on a persistent source of groundwater. For the purpose of site assessment, it is assumed that wetland conditions do not exist where the water table is more than $0.45 \mathrm{~m}$ below the ground surface, which is the maximum mean value of depth to the water table found at the reference site. Figure 4.3.2.1 shows the site immediately after a rain event on June 7, 2001. The figure depicts the pressure head at the ground level. Values of zero or above indicate fully saturated conditions. The entire site is fully saturated with the exception of the berm. Figure 4.3.2.2 shows that on June 8, 2001 (one day after the rain event) the groundwater table has drained to $>0.45 \mathrm{~m}$ below the ground surface along the western edge of the site. Four days after the rain event (June 11, 2001), the ground water table has fallen is 
more than $0.45 \mathrm{~m}$ below the ground surface in over 50 percent of the site (Figure 4.3.2.3). Figure 4.3.2.4 shows the site on June 15, 2001, which is eight days after the rain event. Comparison of the Figures 4.3.2.3 and 4.3.2.4 shows that the site reaches quasi-equilibrium, where moisture conditions stabilize and the depth to the groundwater table remains approximately constant.

These results compare well with the habitat data found by Balcombe (2002). The western portion of the site was predominantly classified as upland habitat (Figure 3.1.1.1). Modeling results show water levels in this portion of the site fall to more than $0.45 \mathrm{~m}$ below the ground surface within four days after a rain event, confirming that wetland vegetation should be inhibited due the lack of a persistent source of groundwater. Further, model results show that most of the eastern portion of remains fully saturated for extended periods of time after a rain event because of contact with the groundwater table. As expected, this portion of the site was found to have wetland habitat by Balcombe (2002).

Groundwater was predicted to flow generally from northeast to southwest. Total head values were highest in the northeastern corner and lowest in the southwestern corner of the site. These flow directions show the stream is groundwater gaining, and confirm that the largest source of water present at the site is groundwater. Ideally, a detailed investigation of the simulated water budget could be used to determine the total amount of water inflows. Unfortunately, the boundary conditions used did not allow for this type analysis. Because the variable flux boundary conditions change from flux to constant head, it is not possible to determine from the model output how much groundwater or precipitation entered the site. The model output only specified inflows from constant head boundaries. Therefore, there is no way to distinguish between the inflows from the site boundaries and from element 
nodes on the interior of the site that are changed to constant head conditions during model simulation.

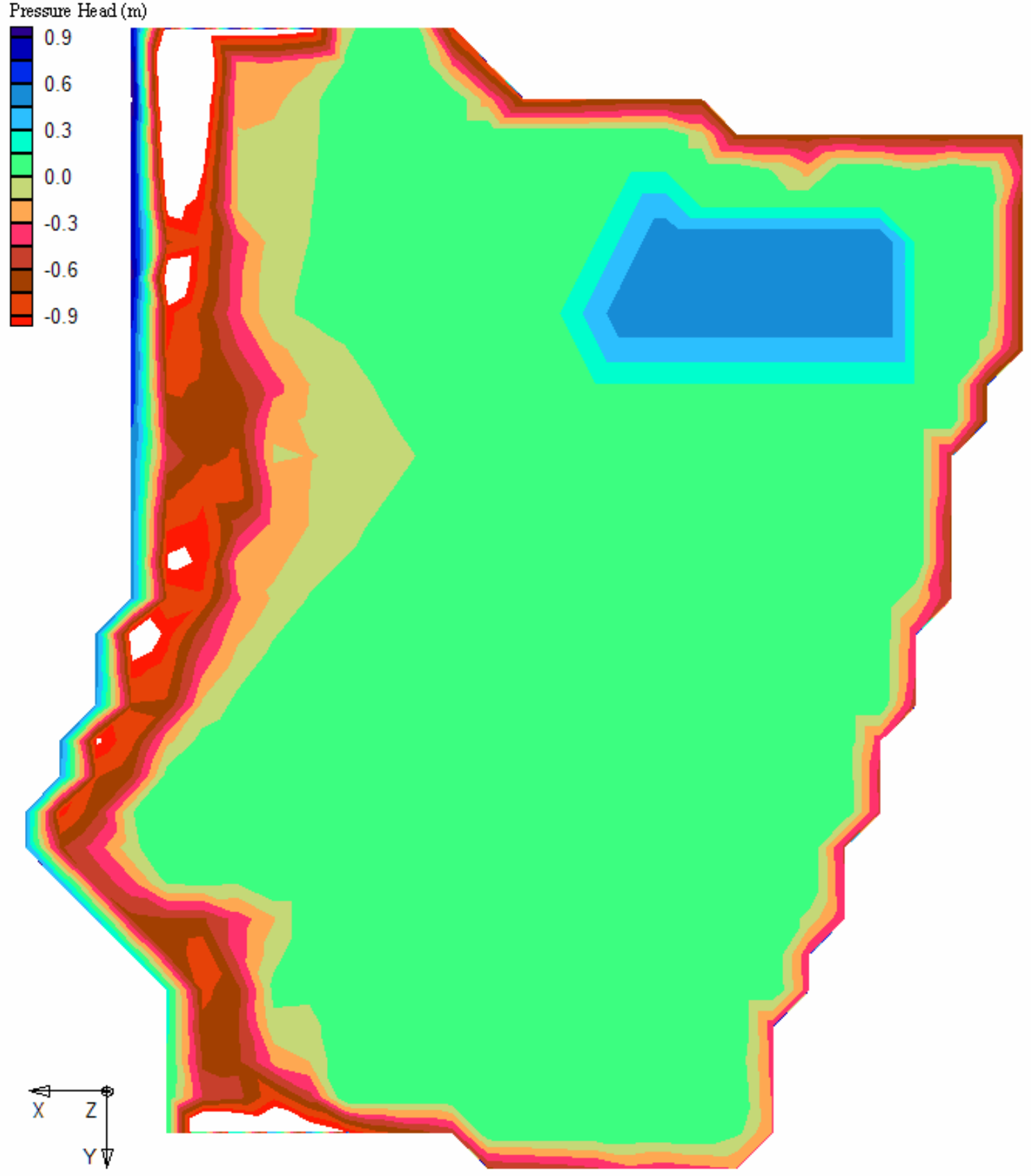

Figure 4.3.2.1. Figure of the Leading Creek hydrologic model showing pressure head at the ground surface on June 7, 2001. 


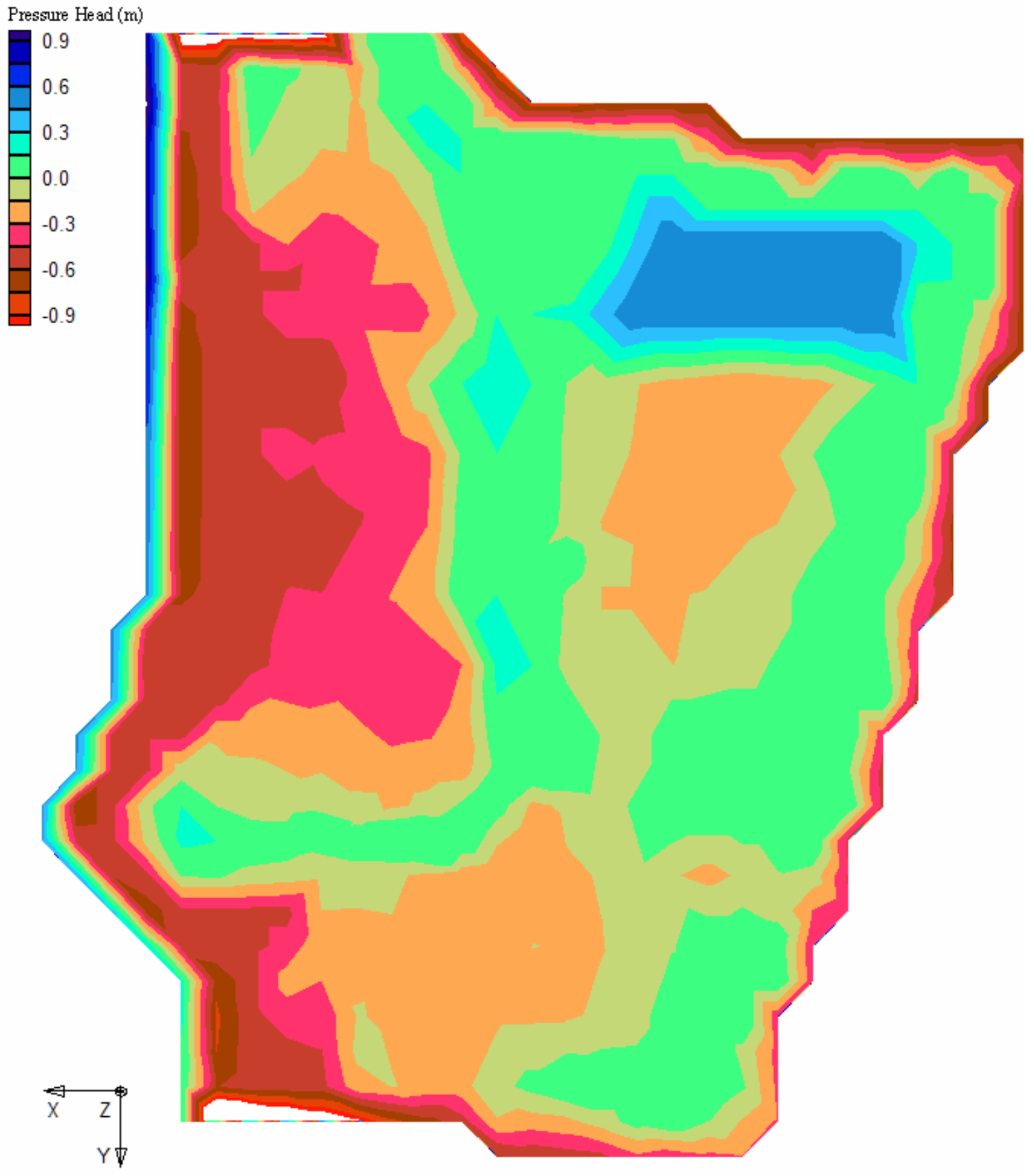

Figure 4.3.2.2. Figure of the Leading Creek hydrologic model showing pressure head at the ground surface on June 8, 2001. 


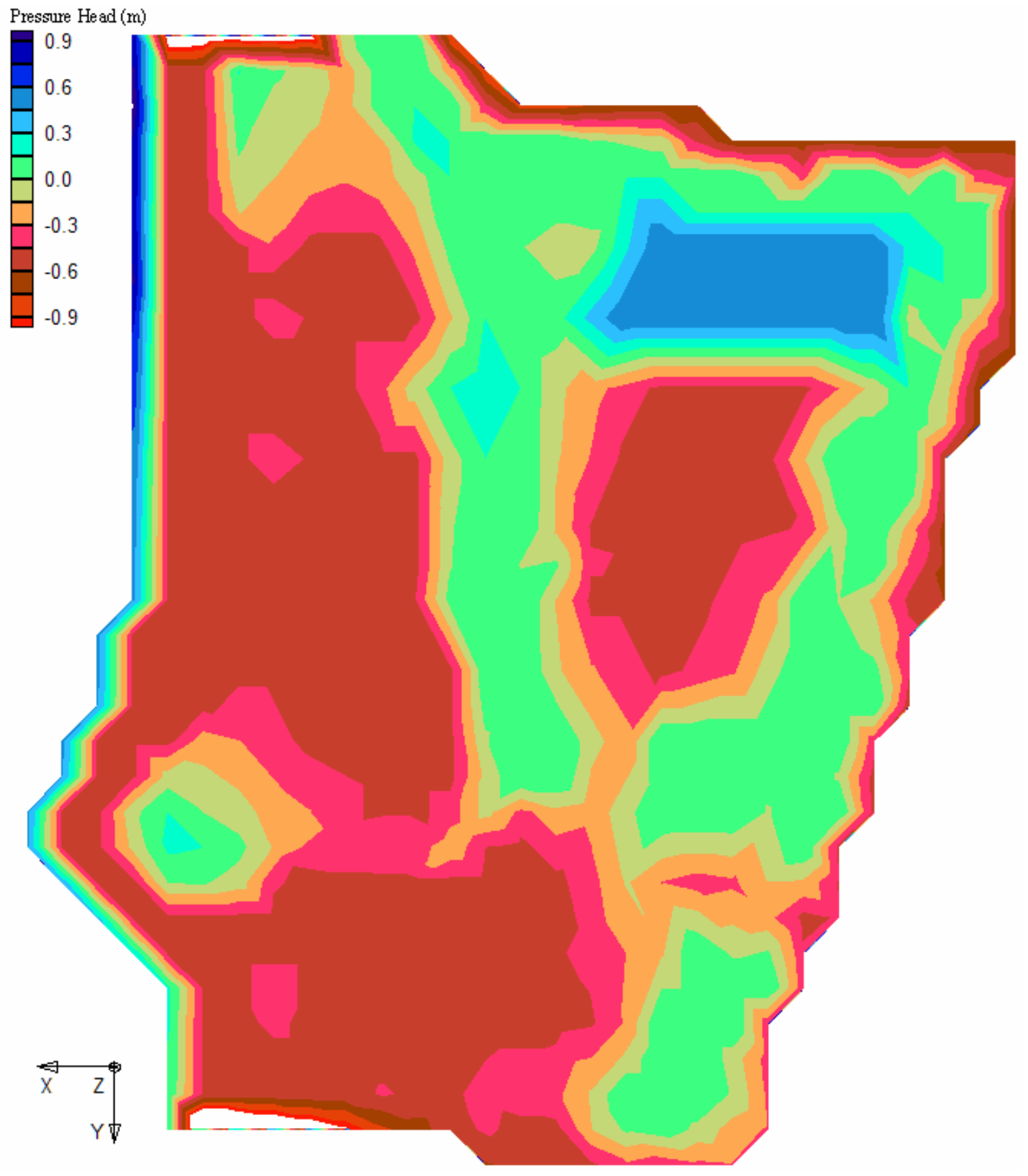

Figure 4.3.2.3. Figure of the Leading Creek hydrologic model showing pressure head at the ground surface on June 11, 2001. 


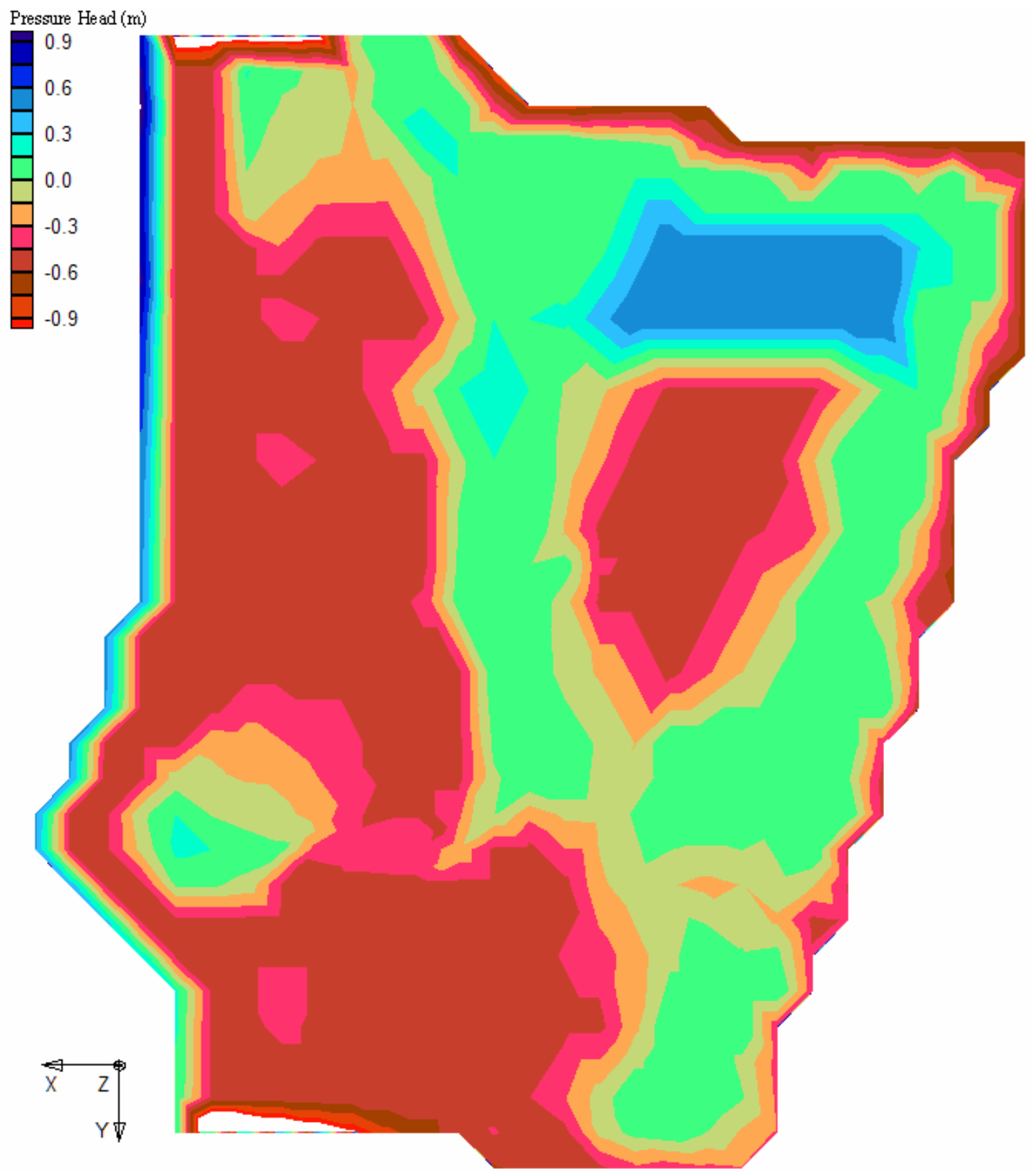

Figure 4.3.2.4. Figure of the Leading Creek hydrologic model showing pressure head at the ground surface on June 15, 2001. 


\section{CHAPTER 5.0 DISCUSSION AND RECCOMENDATIONS}

Creation of a constructed mitigation wetland is a multi-task process consisting of site selection, design and construction, and post-construction monitoring. Of these tasks, properly selecting a mitigation site is the most important because the design and construction methods used will make little difference in the success of the project unless an ample and persistent water source is present. The Environment Law Institute (1993) states:

"The most common failure [of mitigation wetlands] is improper design or construction of the mitigation site's hydrology."

\subsection{SITE SELECTION}

While site selection is the most important step in creating a mitigation wetland, it is also the most difficult. Ideally wetland mitigation sites should be located adjacent to the impacted natural wetland. Unfortunately, this location is commonly not an option because of inadequate size or land ownership constraints. Whenever mitigation can not be implemented adjacent to the impacted site, a two phase site selection process should be implemented.

\subsubsection{Preliminary Site Selection}

Preliminary site selection should consist of identifying several possible sites. Many sources of data are available to identify potential sites. Through the use of GIS programs, current and historic aerial photographs, USGS topographic maps, and other existing data sources, areas potentially appropriate for wetland restoration and creation 
can be identified.

Regulations requiring that wetland mitigation take place in the same watershed as the wetland losses make it useful to utilize GIS programs to isolate possible sites. Major watershed boundaries are generally available for download from various sources. These watershed boundaries can be used to determine the spatial extent of the area available for each wetland mitigation project. USGS topographic maps and Digital Elevation Models (DEM's), which are also frequently available for download, can be used to determine areas with appropriate topography for wetland construction.

Aerial photography of historic land covers can be used to identify areas that previously supported wetland conditions. It is important to identify these sites because hydrophytic seed banks may still exist (Hammer 1992). Current aerial photography can be used to verify suitable onsite and adjacent land uses. Unimproved land covers such as forests areas are the most desirable. Areas with highly altered adjacent land uses, such as industrial or residential sites, should be avoided because of indirect adverse impacts.

\subsubsection{Final Site Selection}

Final site selection is the process of choosing the most desirable areas from those identified during the preliminary site selection process. Because the preliminary site selection process does not involve site visits, conditions that would be detrimental to the formation of wetland habitat may have been overlooked. "Windshield surveys" can be used to identify changes in land cover and other major disturbances that have taken place since the aerial photography and GIS layers were developed.

Final site selection should be performed using formal site selection criteria such as those developed and implemented by WVU and the WVDOH (Appendix B). 
This set of final selection criteria takes into account several facets of wetland development and value. Each facet is scored on a numerical scale with the most likely condition for wetland mitigation ranking high and the least likely ranking low. Multiplication factors are then applied to each facet's score and all of the weighted scores are summed. The area with the highest overall score is then chosen as the preferred site.

Persistent, sufficient water sources are among the most important factors in the selection of a wetland mitigation site. In topography and geology like that of the present study area, shallow groundwater is frequently the most reliable source of water. The presence of shallow groundwater can be inferred from the presence of several items. Streams in broad alluvial filled valleys are commonly gaining streams, which implies that the groundwater table increases in elevation as distance from the stream increases. Existing wetland areas, which have no external water source (e.g. drainage swales), and the presence of hydrophytic vegetation near the site indicate the presence of shallow groundwater. The presence of seeps along or near the toe of a slope also indicates the presence of a shallow groundwater table.

The amount of surface runoff and the frequency of overbank flooding should be investigated. These water sources should be considered secondary hydrologic inputs. Although surface runoff and overbank flooding will provide some hydrologic inputs, they are often unreliable. Surface runoff from upland areas transports essential organic matter and nutrients. In addition, overbank flooding promotes the deposition of sediment that can contain organic matter and nutrients. On the other hand, too frequent flooding can lead to excess sedimentation.

The quality of the onsite and adjacent habitat should be evaluated to 
determine its importance to wildlife. Impacts to high quality onsite and adjacent habitat should be minimized if possible. Conversely, constructing a mitigation wetland adjacent to high quality wildlife habitat is beneficial as long as offsite impacts are minimized.

Surrounding land use should be investigated to minimize disturbance of the newly created site (Environmental Law Institute 1993). Upland buffers around the periphery of the site are ideal, except in situations where natural wetlands are located adjacent to the site. Areas that are surrounded by large amounts of development should be avoided as this can lead to a conversion of the site to upland habitat.

Common construction issues should be investigated to ensure problems do not arise during the construction process. Since many landowners are not forthcoming in providing land to be converted to wetlands, all facets of construction should be confined to the project site so the number of disturbed property owners is minimized. The possible locations of construction access should be identified to determine if additional right-ofway is required. Even though the amount of excavation required is not known during the site selection process, possible waste areas should be located on or near the site. In addition, constructability can add additional costs depending on the type of design that is implemented.

\subsection{SITE DESIGN AND CONSTRUCTION}

Site design should take into account the primary water inputs and nutrient sources. Often the sources of these items will not be the same. Groundwater is the most reliable source of water in regions similar to that of the study area. Direct rainfall will likely not consistently provide the amount of water needed for wetland development. 
Frequent overbank flooding from adjacent streams is hard to predict and can lead to excess sedimentation. Nutrient sources can come from adjacent upland habitat such as forests and from occasional overbank flooding. Hydrologic modeling of the site design should be performed to increase the probability that a hydrologic regime adequate for wetland development will occur.

Constructed mitigation wetlands should be designed to minimize site disturbance. Historically, construction of wetlands required that large amounts of soil be excavated and wasted. This creates surface disturbance and the loss of large amounts of existing organic material. In addition, the associated cost of hauling and wasting excess material leads to higher project costs and larger construction times.

\subsection{POST CONSTRUCTION MONITORING}

Hydrologic monitoring of post construction conditions provides data to determine if wetland hydrology has developed and will persist. If problems exist, this data should be used to isolate the cause and remedy the condition to help maximize the amount of mitigation credits the project will receive. In addition, post construction monitoring “...helps ensure long-term ecological success...” (Environmental Law Institute 1993).

Monitoring the hydrologic conditions at a wetland is relatively simple and inexpensive. Shallow monitoring wells can be installed during construction and monitored on a monthly basis during the first year after construction. After the first year monitoring can be reduced to every other month during the growing season until a reasonable assurance that hydrologic conditions have stabilized has been concluded. In addition, this data can be used to validate any design models that were developed. 


\section{CHAPTER 6.0 SUMMARY AND CONCLUSIONS}

\subsection{SUMMARY}

\subsubsection{Hydrologic Data}

Analysis of the hydrologic data collected at the study sites shows the constructed mitigation wetlands are performing well compared to the reference site with the exception of a few problem areas. The average depth to the water table was less than the maximum $(0.45 \mathrm{~m})$ found at the reference site for all but 5 of the 26 monitoring devices at the mitigation sites. The areas around all but 1 of the 21 monitoring devices that have average water table depths less than the maximum found at the reference site were classified as wetland habitat by Balcombe (2003). Four of the 5 monitoring devices that had a value greater than the maximum found at the reference site were located in upland habitat (Balcombe 2003). The standard deviation of the mean depth to the water table was less than the maximum $(0.15 \mathrm{~m})$ found at the reference site for all but 7 of the 26 monitoring devices. Three of the 7 were located in upland habitat (Balcombe 2003). The remaining 4 were located in wetland habitat (Balcombe 2003).

\subsubsection{Numerical Model}

Results from the numerical model show wetland conditions at the Leading Creek site are highly dependent on the presence of groundwater. Four days after a rain event the water table drops below $0.45 \mathrm{~m}$ from the ground surface in over $50 \%$ of the site. The remainder of the site, where the water table is within $0.45 \mathrm{~m}$ of the surface, is able to support wetland conditions from the presence of groundwater. In addition, a quasi-equilibrium is reached after 4 days, where the conditions remain relatively constant for extended rainless periods. Areas that remained saturated after this amount of time were found to have wetland habitat by 
Balcombe (2002). This indicates that groundwater is the primary source of hydrologic inputs for areas where wetland conditions exist at the site.

Future hydrologic models, which will be used for wetland mitigation site design, should incorporate a high number of instruments around the periphery of the site to better understand the boundary conditions. The largest drawback for the model used in this study was the constant head boundary conditions used throughout the entire simulation. The use of varying boundary conditions would likely have shown higher variability along the site boundaries.

\subsection{CONCLUSIONS}

The limiting factor in the success of a mitigation wetland is not only the availability of hydrologic inputs but also how those inputs are incorporated into the design plan. Identifying sites appropriate for wetland mitigation is crucial to completing a successful wetland mitigation project. In addition, a detailed understanding of site hydrology is needed to develop the proper design. Numerical modeling software, such as was used for this study, should be incorporated during the design process to maximize the probability of project success. Modeling software allows the designer to better predict the hydrologic conditions that will develop. Site design should minimize the amount of construction disturbance. Post construction hydrologic monitoring should be included in the mitigation plan to locate potential problem areas and maximize the success rate. In addition, lessons learned from previous wetland mitigation projects can be used to create more successful future projects. 


\section{CHAPTER 7.0 REFERENCES}

Allen, R. G. (2000). REF-ET: Reference Evapotranspiration Calculation Software for FAO and ASCE Standardized Equations. University of Idaho.

Anderson, M. and Woessner, W. (1992). Applied Groundwater Modeling, Simulation of Flow and Advective Transport. New York, New York: Academic Press.

Balcombe, C. K. (2003). "An Evaluation of Vegetation and Wildlife Communities in Mitigation and Natural Wetlands of West Virginia." M.S. Thesis, West Virginia Univeristy.

Brigham Young University (BYU). (2000). GMS v3.1: Tutorials. Brigham Young University - Environmental Modeling Research Laboratory.

Carter, Jimmy. (1977). Executive Order 11990. "Protection of Wetlands". Federal Register 42: 26961 .

Carter, V., Bedinger, M., Novitzki, R., and Wilen, W. (1978). Water Resources and Wetlands. Wetland Function and Value: The State of Our Understanding. American Water Resources Association. pp. 344-376.

Clark, J. and Clark, J. (1979). National Symposium on Wetlands-Scientists’ Report. National Wetlands Technical Council, Washington, D.C.

Cowardin, L. (1995). Classification of Wetlands and Deepwater Habitats of the United States. Washington, D.C.: U.S. Department of the Interior, Fish and Wildlife Service. 
Dahl, T. and Johnson, C. (1991). Staus and Trends of Wetlnads in the Conterminous United States, Mid-1970's to Mid-1980's. Washington, D.C.: U.S. Department of the Interior, Fish and Wildlife Service.

Diehl, J. and Behling, R. (1982). Geologic Factors Affecting Formation and Presence of Wetlands in the North Central Section of the Appalachian Plateaus Province of West Virginia. Proceedings: Symposium on Wetlands of the Unglaciated Appalachian Region, West Virginia University, Morgantown, WV. pp. 3-9.

Dennison, M. and Berry, J. (1993). Wetlands: Guide to Science, Law, and Technology. Park Ridge, New Jersey: Noyes Publication.

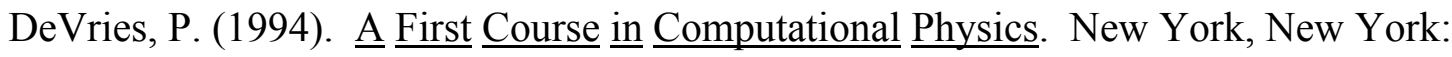
John Wiley and Sons, Inc.

Environmental Law Institute. (1993). Wetland Mitigation Banking. Washington, D.C.: Environmental Law Institute.

Erickson, P., Camougis, G., Miner, N. (1980). Highways and Wetlands, Volume II: Impact Assessment, Mitigation, and Enhancement Measures. Washington, D.C.: U.S. Department of Transportation, Federal Highway Administration Office of Development,

Feierabend, J. (1992). Endangered Species - Endangered Wetlands: Life in the Edge. National Wildlife Federation, Washington, D.C.

Fortney, R. (2001). Personal Communication.

Fortney, R., Copen, S., Messenger, B., and Anderson, J. (2003). Engineering Evaluation of Eleven Constructed Mitigation Wetlands. Report submitted to the West Virginia Department of Natural Resources. 
Fortney, R., Edinger, B., Michael, E., and Sencindiver, J. (2000). Functional Assessment of Three Wetlands Constructed by the West Virginia Division of Highways. Technical Report. Contract No. RP 130. West Virginia Division of Highways, Charleston, WV.

Golden Software, Inc. (2002). Surfer ${ }^{\circledR} 8$ User's Guide. Golden, Colorado.

Hammer, D. (1992). Creating Freshwater Wetlands. Boca Raton, Florida: Lewis Publishers.

Hayes, D., Trudy, O., Fischenich, J., and Palermo, M. (2000). Wetlands Engineering Handbook. US Army Corps of Engineers, Engineering Research and Development Center.

Jensen, M. E., R. D. Burman, and R. G. Allen. (1990). Evapotranspiration and Irrigation Water Requirements. American Society of Civil Engineers, Engineering Practice Manual No. 70.

Lin, H., Richards, D., Talbot, C., Yeh, G., Cheng, J., Cheng, H., and Jones, N. (1997). FEMWATER: A Three-Dimensional Finite Element Computer Model for Simulating Density Dependent Flow and Transport in Variably Saturated Media. U.S Army Corps of Engineers, Waterways Experiment Station; Department of Civil and Environmental Engineering, Pennsylvania State University; and Department of Civil Engineering, Engineering Computer Graphics Laboratory, Brigham Young University.

Messenger, R. (2001). Personal Communication.

Metzler, K. and Tiner, R. (1992). Wetlands in Connecticut. United States Fish and 
Wildlife Service, Washington, D.C.

Mitsch, W. and Gosselink, J. (2000). Wetlands, Third Edition. New York: John Wiley and Sons, Inc.

Nace, R. and Bieber, P. (1958). Ground Water Resources of Harrison County West Virginia: West Virginia Geological and Economic Survey, Bulletin No. 14.

National Research Council. (2001). Compensating for Wetland Losses Under the $\underline{\text { Clean }}$ Water Act. Washington, D.C.: National Academy Press.

National Wetlands Policy Forum. (1988). Protecting America's Wetlands: An Action Agenda, Conservation Foundation, Washington, DC. 69 pp.

Remote Data Systems, Inc. (2001). Product Literature.

Smith, L. and Michael, E. (1982). Values of Wetlands in the Unglaciated Mountain Region. Proceedings: Symposium on Wetlands of the Unglaciated Appalachian Region, West Virginia University, Morgantown, WV. pp. 239-253.

Smith, R. and Smith, T. (2001). Ecology \& $\underline{\text { Field Biology, }}$ Sixth Edition. New York: Benjamin Cummings.

Tiner, R. (1984). Wetlands of the United States: Current Status and Recent Trends. United States Fish and Wildlife Service, Washington, D.C. 


\section{APPENDIX A}

Table A.1. Depth to the water table at the eastern side of the Leading Creek wetland. (Ground level $=0$ )

\begin{tabular}{ccccccccc}
\hline \multirow{2}{*}{$\begin{array}{c}\text { Date } \\
\text { Observed }\end{array}$} & \multicolumn{7}{c}{ Water Level Relative to Ground Surface (cm) } \\
\cline { 2 - 7 } & LC7 & LC8 & LC9 & LC10 & LC11 & LC12 & LC13 & LC-R2* \\
\hline $6 / 5 / 01$ & +2.7 & +6.5 & -50.7 & +9.4 & -33.6 & -25.2 & +5.8 & +1.5 \\
$6 / 27 / 01$ & -7.3 & -0.5 & -67.7 & -8.6 & WD & -27.2 & +3.8 & -29.2 \\
$7 / 9 / 01$ & -5.8 & -2.1 & -50.5 & -7.1 & -64.2 & -19.7 & +4.6 & -20.3 \\
$8 / 1 / 01$ & -1.3 & +1.0 & -29.7 & -4.6 & -32.6 & -15.2 & +4.8 & +2.0 \\
$8 / 13 / 01$ & -2.8 & -2.0 & -40.7 & -7.1 & -42.6 & -18.2 & -1.2 & -11.2 \\
$9 / 6 / 01$ & -11.3 & -11.5 & -75.2 & -12.1 & -72.6 & -34.2 & -3.2 & ND \\
$10 / 11 / 01$ & -15.3 & -15.5 & WD & -16.1 & -70.6 & -41.7 & -9.2 & ND \\
$11 / 6 / 01$ & -10.8 & -13.5 & WD & -17.1 & WD & -44.2 & -11.2 & ND \\
$12 / 29 / 01$ & ND & ND & -63.7 & -4.6 & -60.6 & -30.2 & +4.8 & ND \\
$1 / 21 / 01$ & +0.7 & +0.5 & -57.7 & -4.6 & -56.6 & -30.2 & +1.8 & -7.4 \\
$2 / 17 / 01$ & -1.3 & +0.5 & -57.7 & -22.1 & -60.6 & -29.2 & +4.8 & -18.1 \\
$3 / 24 / 01$ & +6.7 & +6.5 & -26.7 & -1.6 & -65.6 & -25.2 & -10.2 & +8.1 \\
$4 / 25 / 01$ & +0.7 & +7.0 & -30.7 & -0.1 & -38.6 & -24.2 & +8.8 & +8.4 \\
$5 / 27 / 01$ & -6.8 & -3.0 & -67.7 & -6.6 & WD & -30.2 & +3.3 & -22.9 \\
\hline & & & & & & &
\end{tabular}

Note: $\mathrm{ND}=$ No Data, $\mathrm{WD}=$ Well Dry

*Values shown for LC-R2 are average daily values.

${ }^{+}$Positive values indicate flooding. 
Table A.2. Depth to the water table at the western side of the Leading Creek wetland. (Ground level = 0)

\begin{tabular}{|c|c|c|c|c|c|c|c|c|}
\hline \multirow{2}{*}{$\begin{array}{c}\text { Date } \\
\text { Observed }\end{array}$} & \multicolumn{8}{|c|}{ Water Level Relative to Ground Surface $(\mathrm{cm})^{+}$} \\
\hline & LC1 & LC2 & LC3 & LC4 & LC5 & LC6 & LC-P1 & LC-P3 \\
\hline $6 / 5 / 01$ & -51.9 & -53.6 & -8.3 & -13.3 & -7.2 & +1.3 & -31.7 & +2.3 \\
\hline $6 / 27 / 01$ & -61.9 & -71.6 & -8.3 & -21.2 & -14.3 & +0.9 & -45.7 & -5.7 \\
\hline $7 / 9 / 01$ & -60.0 & -69.3 & -1.0 & -19.9 & -11.6 & +0.7 & -45.7 & -3.7 \\
\hline $8 / 1 / 01$ & -53.9 & -59.6 & -0.4 & -14.9 & -8.4 & +1.4 & -22.7 & -2.7 \\
\hline $8 / 13 / 01$ & -59.9 & -65.6 & -0.2 & -20.4 & -8.8 & +0.9 & -46.2 & -8.2 \\
\hline $9 / 6 / 01$ & -78.4 & -85.6 & -14.8 & -33.6 & -17.5 & -2.3 & -57.7 & -4.7 \\
\hline $10 / 11 / 01$ & -91.9 & -104.6 & -20.1 & -36.1 & -21.0 & -3.3 & -67.7 & -5.2 \\
\hline $11 / 6 / 01$ & -105.9 & -115.1 & -21.7 & -38.9 & -23.8 & -2.3 & -75.7 & -4.7 \\
\hline $12 / 29 / 01$ & -52.9 & -63.6 & -5.5 & -21.6 & -11.6 & -0.7 & -40.7 & -2.7 \\
\hline $1 / 21 / 01$ & -58.9 & -62.6 & -2.4 & -16.5 & -9.6 & +0.1 & -44.7 & -4.7 \\
\hline $2 / 17 / 01$ & -58.9 & -115.6 & -2.0 & -18.4 & -10.8 & -16.5 & -40.7 & +0.8 \\
\hline $3 / 24 / 01$ & -49.4 & -54.6 & -1.2 & -14.5 & -8.4 & -7.4 & -42.7 & -0.7 \\
\hline $4 / 25 / 01$ & -50.9 & -48.6 & -1.0 & -16.3 & -8.2 & +0.1 & -24.7 & -4.3 \\
\hline $5 / 27 / 01$ & -59.9 & -62.6 & -5.2 & -19.2 & -11.6 & -3.1 & -31.7 & +0.3 \\
\hline
\end{tabular}


Table A.3. Depth to the water table at the Sugar Creek wetland. (Ground level $=0$ )

\begin{tabular}{cccccccc}
\hline \multirow{2}{*}{$\begin{array}{c}\text { Date } \\
\text { Observed }\end{array}$} & \multicolumn{7}{c}{ Water Level Relative to Ground Surface (cm) } \\
\cline { 2 - 8 } & SC1 & SC2 & SC3 & SC4 & SC5 & SC6 & SC7 \\
\hline $8 / 1 / 01$ & -4.2 & -10.9 & +0.6 & +14.8 & +2.7 & -1.7 & +0.1 \\
$8 / 13 / 01$ & -10.2 & -13.9 & -1.4 & +6.3 & -11.3 & -3.7 & -0.9 \\
$9 / 6 / 01$ & -14.7 & -16.4 & +8.1 & -1.2 & -18.3 & -0.7 & +0.6 \\
$9 / 27 / 01$ & -31.7 & -18.9 & -4.4 & -12.2 & -21.8 & -4.7 & -2.4 \\
$10 / 25 / 01$ & -66.2 & -26.9 & -20.9 & -37.2 & -63.3 & -21.7 & -11.9 \\
$11 / 6 / 01$ & -37.7 & -18.9 & -8.4 & -16.7 & -41.3 & -15.2 & -9.4 \\
$12 / 29 / 01$ & -20.7 & -12.4 & -3.4 & -4.2 & -21.8 & -6.7 & -3.9 \\
$1 / 21 / 01$ & -15.2 & -13.4 & -2.4 & -0.2 & -16.3 & -1.7 & +0.1 \\
$2 / 23 / 01$ & -14.2 & -10.4 & -0.9 & -0.7 & -15.8 & -0.7 & +1.2 \\
$3 / 24 / 01$ & -6.2 & -6.9 & +1.6 & +1.8 & -8.3 & +8.3 & +7.2 \\
$4 / 25 / 01$ & -1.2 & -3.9 & +3.6 & +2.8 & -4.8 & +10.3 & +10.7 \\
$5 / 27 / 01$ & -33.2 & -12.9 & +0.6 & -5.2 & -26.3 & -0.7 & +1.2 \\
\hline
\end{tabular}

Note: $\mathrm{ND}=$ No Data, $\mathrm{WD}=$ Well Dry

${ }^{+}$Positive values indicate flooding. 
Table A.4. Depth to the water table at the Triangle wetland. (Ground level $=0$ )

\begin{tabular}{cccc}
\hline \multirow{2}{*}{$\begin{array}{c}\text { Date } \\
\text { Observed }\end{array}$} & \multicolumn{3}{c}{ Water Level Relative to Ground Surface (cm) } \\
\cline { 2 - 4 } & TRI1 & TRI2 & TRI3 \\
\hline $8 / 1 / 01$ & -14.5 & -14.8 & -14.0 \\
$8 / 13 / 01$ & -12.5 & -15.8 & -15.5 \\
9/7/01 & -9.0 & -14.8 & -17.0 \\
9/27/01 & -11.5 & -12.3 & -15.0 \\
10/11/01 & -19.0 & -23.8 & -40.0 \\
10/25/01 & -18.5 & -21.8 & -33.0 \\
11/6/01 & -10.0 & -17.8 & -22.5 \\
12/29/01 & -3.5 & -15.3 & -14.0 \\
1/21/01 & +1.5 & -12.8 & -8.0 \\
2/23/01 & -1.5 & -9.8 & -8.0 \\
3/24/01 & -3.5 & -8.8 & -7.0 \\
$4 / 25 / 01$ & -2.5 & -9.3 & -6.5 \\
5/27/01 & -4.5 & -15.3 & -6.0 \\
\hline ND No Data, WD $=$ Well Dry & \\
\hline+ Positive values indicate flooding. &
\end{tabular}


Table A.5. Depth to the water table at of the Meadowville wetland. (Ground level = 0)

\begin{tabular}{|c|c|c|c|c|c|c|c|c|c|c|}
\hline \multirow{2}{*}{$\begin{array}{c}\text { Date } \\
\text { Observed }\end{array}$} & \multicolumn{10}{|c|}{ Water Level Relative to Ground Surface (cm) } \\
\hline & MV1 & MV2 & MV3 & MV4 & MV5 & MV6 & MV-P1 & MV-P2 & MV-P3 & MV-P4 \\
\hline $6 / 5 / 01$ & -30.3 & -31.3 & -22.9 & -32.3 & -7.7 & -10.5 & +6.5 & -24.8 & +12.8 & -16.3 \\
\hline $6 / 27 / 01$ & -56.3 & -37.3 & -44.9 & -43.3 & -28.7 & -35.5 & +9.5 & -18.8 & +19.3 & -24.3 \\
\hline $7 / 9 / 01$ & -41.7 & -28.9 & -44.9 & -32.8 & -18.0 & -25.2 & +3.8 & -19.1 & +9.8 & -14.3 \\
\hline $8 / 1 / 01$ & -37.3 & -28.3 & -37.9 & -38.3 & -22.7 & -31.0 & +11.5 & -17.3 & +24.3 & -10.3 \\
\hline $8 / 13 / 01$ & -38.3 & -32.3 & -40.9 & -39.8 & -15.2 & -30.5 & +10.0 & -14.8 & +27.8 & -19.3 \\
\hline 9/7/01 & -40.3 & -39.8 & -42.4 & -41.3 & -22.2 & -32.0 & +9.5 & -16.8 & +25.3 & -26.8 \\
\hline $9 / 27 / 01$ & -38.3 & -39.8 & -45.4 & -44.3 & -19.7 & -34.5 & -3.0 & -21.8 & +22.3 & -46.3 \\
\hline $10 / 11 / 01$ & -62.8 & -56.3 & -63.9 & -55.3 & -39.7 & -52.5 & -10.5 & -25.3 & +12.3 & -51.3 \\
\hline $10 / 25 / 01$ & -64.3 & -56.3 & -62.9 & -62.3 & -36.2 & -51.5 & -19.5 & -28.3 & +3.3 & -61.3 \\
\hline $11 / 6 / 01$ & -50.3 & -44.8 & -54.4 & -42.8 & -14.7 & -31.0 & -10.5 & -18.8 & +7.3 & -47.8 \\
\hline $12 / 29 / 01$ & -35.3 & -31.8 & -46.9 & -37.3 & -11.7 & -21.5 & -3.5 & -26.3 & +9.3 & -37.3 \\
\hline $1 / 21 / 01$ & -32.3 & -27.3 & -44.9 & -47.3 & -15.7 & -19.5 & -0.5 & -25.8 & +11.3 & -33.3 \\
\hline $2 / 28 / 01$ & -36.3 & -32.3 & -47.4 & -42.3 & -13.2 & -16.0 & +4.5 & -19.3 & +17.3 & -36.3 \\
\hline $3 / 24 / 01$ & -30.3 & -25.3 & -39.9 & -34.8 & -10.7 & -10.0 & -6.0 & -16.8 & +19.3 & -30.3 \\
\hline $4 / 25 / 01$ & -28.8 & -21.8 & -36.9 & 30.3 & -6.7 & -6.5 & +6.5 & -16.3 & +16.3 & -24.8 \\
\hline $5 / 27 / 01$ & -44.3 & -34.3 & -46.9 & -44.8 & -18.7 & -26.5 & +5.5 & -11.3 & +17.3 & -22.3 \\
\hline
\end{tabular}

Note: $\mathrm{ND}=$ No Data, $\mathrm{WD}=$ Well Dry

${ }^{+}$Positive values indicate flooding. 
Table A.6. Calculated values of mean depth to the water table and deviation from mean depth to the water table for each well at the Leading Creek, Sugar Creek, Triangle, and Meadowville study sites. (Ground level $=0$

m)

\begin{tabular}{|c|c|c|c|}
\hline Site & Well No. & $\bar{x}(\mathbf{m})$ & $\sigma(\mathbf{m})$ \\
\hline \multirow{16}{*}{$\begin{array}{l}\text { Leading } \\
\text { Creek }\end{array}$} & $\mathrm{LC} 1$ & -0.64 & 0.17 \\
\hline & LC2 & -0.74 & 0.23 \\
\hline & LC3 & -0.17 & 0.19 \\
\hline & $\mathrm{LC} 4$ & -0.55 & 0.21 \\
\hline & LC5 & -0.31 & 0.13 \\
\hline & LC6 & -0.05 & 0.12 \\
\hline & $\mathrm{LC} 7$ & -0.04 & 0.06 \\
\hline & LC8 & -0.02 & 0.07 \\
\hline & LC9 & -0.52 & 0.16 \\
\hline & LC10 & -0.07 & 0.08 \\
\hline & LC11 & -0.54 & 0.15 \\
\hline & LC12 & -0.28 & 0.08 \\
\hline & $\mathrm{LC} 13$ & 0.01 & 0.07 \\
\hline & LC-R2 & -0.09 & 0.14 \\
\hline & LC-P1 & -0.44 & 0.15 \\
\hline & LC-P3 & -0.03 & 0.03 \\
\hline \multirow{7}{*}{ Sugar Creek } & $\mathrm{SC} 1$ & -0.24 & 0.21 \\
\hline & $\mathrm{SC} 2$ & -0.15 & 0.07 \\
\hline & $\mathrm{SC} 3$ & -0.04 & 0.09 \\
\hline & $\mathrm{SC} 4$ & -0.07 & 0.15 \\
\hline & SC5 & -0.24 & 0.21 \\
\hline & SC6 & -0.05 & 0.10 \\
\hline & $\mathrm{SC} 7$ & -0.02 & 0.07 \\
\hline \multirow{3}{*}{ Triangle } & TRI1 & -0.08 & 0.07 \\
\hline & TRI2 & -0.15 & 0.04 \\
\hline & TRI3 & -0.16 & 0.10 \\
\hline \multirow{10}{*}{ Meadowville } & MV1 & -0.42 & 0.11 \\
\hline & MV2 & -0.35 & 0.10 \\
\hline & MV3 & -0.45 & 0.10 \\
\hline & MV4 & -0.19 & 0.09 \\
\hline & MV5 & -0.42 & 0.08 \\
\hline & MV6 & -0.27 & 0.13 \\
\hline & MV-P1 & 0.02 & 0.09 \\
\hline & MV-P2 & -0.20 & 0.05 \\
\hline & MV-P3 & 0.16 & 0.07 \\
\hline & MV-P4 & -0.31 & 0.15 \\
\hline
\end{tabular}




\begin{abstract}
APPENDIX B
The wetland mitigation site selection process shown below has been developed for West Virginia and areas with similar topographic relief. These criteria have been evolving since 1999 and are currently being finalized for final approval by the WVDOH. Input of several individuals with many backgrounds has been instrumental in developing these comprehensive selection criteria. Myself along with Dr. James T Anderson ${ }^{2}$, Dr. Darrell R. Dean ${ }^{l}$, Jr., Dr. Ronald Fortney ${ }^{1}$, Dr. Donald D. Gray ${ }^{1}$, Joseph Osbourne ${ }^{2}$, and Dr. Michael Strager ${ }^{3}$ have been involved in the continual evolution of this selection criteria.

${ }^{I}$ West Virginia University Department of Civil and Environmental Engineering

${ }^{2}$ West Virginia University Division of Forestry

${ }^{3}$ West Virginia University Natural Resources Analysis Center
\end{abstract}

\title{
WETLAND MITIGATION BANKING SELECTION PROCESS
}

The selection of mitigation banking locations can be a complicated and difficult task. A hierarchical approach that eliminates sites at different levels of analysis allows the investigators to streamline the selection process and conserve time, effort, and money. This ranking system is a 3 level model for selecting optimal mitigation banking sites. Level 1 is a coarse filter involving the analysis of Geographic Information System (GIS) and remote sensing data. Level 2 involves field reconnaissance evaluation of the sites selected in level 1 based on ecological, design/construction, and anthropogenic factors. Level 3 is the final selection process in which sites chosen in level 2 are subjected to quantitative assessment through specific field evaluation criteria. Weights will be added to factors in Levels 2 and 3 using a pairwise comparison test so that an objective distinction can be made between factors that are considered more important than others for the success of a mitigation bank site. This document provides the criteria for Levels 1 and 2. The evaluation procedures for Level 3 are outlined in the proposal for this project and are still being modified. This scheme is not only logical, but provides a means for evaluating related criteria independent of unrelated criteria. This hierarchical approach provides the most efficient and effective means of selecting optimal wetland mitigation banking site.

\section{LEVEL 1: OFFICE GIS ANALYSIS}

The first step in ranking potential mitigation banking sites is the evaluation of existing data on wetland characteristics available in GIS format. These criteria are considered mandatory for consideration in Level 2. Therefore, a boolean or yes/no evaluation has been established for the evaluation of Level 1 criteria with $\mathrm{Y}=\mathrm{Yes}$ and $\mathrm{N}=$ no. Sites must obtain a (Y) in all 3 Level 1 criteria to be considered in Level 2.

\section{1-1. Soil Conditions (SSURGO digital soil coverage)}

Hydric or somewhat poorly drained soils are a vital component of wetland ecosystems. Having these soils present Onsite greatly reduces the cost of wetland restoration or construction because the soils do not have to be brought in from another site. 


\begin{tabular}{cl}
\hline Evaluate? & \multicolumn{1}{c}{ Factor } \\
\hline Y & Hydric or somewhat poorly drained soils present \\
N & Moderately or well drained soils present \\
\hline
\end{tabular}

\section{1-2. Wetland Occurrences (NWI digital wetland coverage)}

The presence of historical or current wetlands on or near a site indicates that wetland restoration or construction would add to an existing wetlands in the area. Sites with no history of wetlands may be difficult to convert and may provide valuable ecological benefit as upland habitat.

\begin{tabular}{cl}
\hline Evaluate? & \multicolumn{1}{c}{ Factor } \\
\hline Y & NWI wetland occurrence on or adjacent to site \\
N & No evidence of wetlands on or near site \\
\hline
\end{tabular}

\section{1-3. Existing Land Cover (NLCD Level 2 Anderson Model)}

Impermeable developed areas like parking lots and housing developments are extremely costly and difficult to convert to wetlands. These areas should be eliminated through the above factors, but if they are not criterion will perform this task.

\begin{tabular}{cl}
\hline Evaluate? & \multicolumn{1}{c}{ Factor } \\
\hline $\mathrm{Y}$ & Natural land cover and permeable developed surfaces \\
$\mathrm{N}$ & Impermeable developed areas \\
\hline
\end{tabular}

\section{LEVEL 2: RECONNAISSANCE SURVEY}

Once Level 1 has been completed and a short list of sites with the proper soils and wetland history has been created, field reconnaissance visits should be conducted to further reduce the number of sites for evaluation. To quantitatively analyze these sites, a pairwise comparison test will be conducted to at 2 levels. Level 1 will provide weight factors for ecological, design and construction, and anthropogenic factors and level 2 will provide weights for each factor within these categories.

\section{ECOLOGICAL FACTORS}

\section{2-1. Site Hydrologic Inputs and Hydrologic Regimes}

The hydrological inputs of a wetland are critical attributes of a wetland site. They are also considered by wetland scientists to be difficult attributes to measure and describe because of the time and expense required to conduct field hydrologic measurements. However, the general nature of hydrologic inputs and site hydrologic regimes can be generally inferred through reconnaissance-type site observations of soil conditions, surface features (e.g., drift lines), and site geomorphology. A combination of site 
observations and references to county soil surveys can generally produce enough information to permit a reasonably confident prediction that there is or is not a reasonable potential to re-establish or create wetland hydrologic regimes. There are 3 basic hydrologic inputs: groundwater, overbank flooding, and surface runoff. Surface runoff alone is not enough to support a functioning wetland environment. Evidence of groundwater or overbank flooding must be present in addition to surface runoff for a site to get a hydrologic rating greater than 0 .

\section{2-1a. Groundwater input}

The site either currently has a high seasonal groundwater table or could have a high seasonal groundwater table with reasonable grading.

\begin{tabular}{cl}
\hline Scale & \multicolumn{1}{c}{ Factor } \\
\hline 5 & $\begin{array}{l}\text { High probability of high seasonal groundwater table throughout the growing } \\
\text { season } \\
\text { Moderate probability of high seasonal groundwater table during the growing } \\
\text { season }\end{array}$ \\
1 & $\begin{array}{l}\text { High probability of high seasonal groundwater table only during winter and } \\
\text { spring periods }\end{array}$ \\
0 & High probability of no high seasonal groundwater table \\
\hline
\end{tabular}

\section{2-1b. Overbank Flooding}

The site conditions exist to permit the use of annual overbank flooding as a principal component of establishing desired hydrologic regimes. Either overbank flooding currently exists or could be created through reasonable changes of site elevations.

\begin{tabular}{cl}
\hline Scale & \multicolumn{1}{c}{ Factor } \\
\hline 5 & High probability of a regular flooding cycle; physical evidence of flooding \\
3 & regime \\
1 & High probability of regular flooding with minor construction \\
0 & Low probability of regular flooding with major construction \\
\hline
\end{tabular}

\section{2-1c. Surface Runoff}

The site either currently receives surface runoff or could receive surface runoff with reasonable manipulation of site surface conditions. 


\begin{tabular}{cl}
\hline Scale & \multicolumn{1}{c}{ Factor } \\
\hline 5 & High probability that adequate surface runoff occurs on the site \\
3 & High probability of adequate surface runoff with minor construction \\
1 & High probability of adequate surface runoff with major construction \\
0 & Low probability of adequate surface runoff even with construction \\
\hline
\end{tabular}

\section{2-2. Existing Land Cover}

Refers to the existing conditions of each site and the potential for wetland enhancement without disturbing existing upland habitat. Non-forested sites are preferred due to the expense of clearing wooded vegetation and the associated secondary impacts. A mixture of habitats is preferred, provided that wetland creation could be incorporated into existing conditions.

\begin{tabular}{cl}
\hline Scale & \multicolumn{1}{c}{ Factor } \\
\hline 5 & Highly disturbed (i.e. reclaimed mining land) \\
3 & Open agricultural land (i.e. pasture, cropland, naturalized meadow) \\
1 & Agricultural land with scattered wood lots \\
0 & Wooded (shrub or forest) or developed land \\
\hline
\end{tabular}

\section{2-3. Wetland Occurrences}

Refers to the presence or absence of wetlands within or adjacent to a candidate wetland mitigatiOnsite. The occurrence of wetlands on portions of a site may be used as an indicator of the possible historical presence of wetlands. It is preferable to have wetlands on or adjacent to mitigatiOnsites. However, it is not preferable for the construction of a mitigation wetland to negatively impact existing high quality wetland, e.g., alteration the hydrology of adjacent wetland that supports a population of rare or endangered species.

\begin{tabular}{cl}
\hline Scale & \multicolumn{1}{c}{ Factor } \\
\hline 5 & Indicators present for historic wetlands on or adjacent to site \\
3 & $\begin{array}{l}\text { Presence of wetlands on project site or on adjacent sites } \\
\text { No wetlands or evidence of historic wetlands present on-site or on adjacent } \\
\text { sites }\end{array}$ \\
\hline
\end{tabular}

\section{2-4. Wooded Buffer}

Refers to existing wooded buffer conditions. An existing wooded buffer separating the mitigatiOnsite from adjacent land uses is preferred. The wooded buffer must be within $50 \mathrm{~m}$ of the site and at least $100 \mathrm{~m}$ wide perpendicular to the site or wooded buffer rating $=0$. 


\begin{tabular}{cl}
\hline Scale & \multicolumn{1}{c}{ Factor } \\
\hline 5 & Present and intact on all perimeters \\
3 & Present and intact on more than $50 \%$ of the site perimeter \\
1 & Present and intact on less than $50 \%$ of the site perimeter \\
0 & Absent on all perimeters \\
\hline
\end{tabular}

\section{2-5. Water Quality}

Refers to the overall water quality of the principal water sources for the site. The highest rating is for water sources that have no significant impairments, e.g., no acid mine drainage, over enrichment from agricultural runoff, or high sediment loads.

\begin{tabular}{cl}
\hline Scale & \\
\hline 5 & No impairments of water sources \\
3 & Moderately impaired water sources \\
0 & Strongly impaired water sources \\
\hline
\end{tabular}

\section{2-6. Value of Site for Wildlife Habitat}

\section{2-6a. On-site Wildlife Habitat Value}

Refers to the availability and utilization of existing wildlife habitats on the site under evaluation. The enhancement potential of a site is rated higher than existing high wildlife values.

\begin{tabular}{cl}
\hline Scale & \multicolumn{1}{c}{ Factor } \\
\hline 5 & Disturbed (i.e. mining land) \\
3 & Active agricultural land: cropland or pasture \\
1 & Mixed land uses or discontinuous single natural community \\
0 & Diverse mosaic of natural communities or continuous single natural community \\
\hline
\end{tabular}

\section{2-6b. Surrounding Wildlife Habitat Value}

Refers to the availability and utilization of existing wildlife habitats on the lands surrounding the site under evaluation. Existing high wildlife value is rated high because this condition enhances the potential wildlife value of the evaluatiOnsite.

\begin{tabular}{cl}
\hline Scale & \multicolumn{1}{c}{ Factor } \\
\hline 5 & $\begin{array}{l}\text { Multiple habitat types juxtaposed for easy movement and access by terrestrial } \\
\text { and aquatic species }\end{array}$ \\
3 & $\begin{array}{l}\text { Single continuous natural community suitable for select species } \\
\text { Fragmented patches of habitat types or fragmented single natural community } \\
\text { creating difficult access and exposed movement corridors }\end{array}$ \\
0 & $\begin{array}{l}\text { Lack of habitat structure and variability; site dominated by open water, bare } \\
\text { ground, or developed areas }\end{array}$ \\
\hline
\end{tabular}




\section{2-7. Possibility of On-Site Biotic Recolonization}

Refers to the potential for voluntary colonization by hydrophytic plants and wildlife and the occurrence of natural wetland successional processes. Good indicators are the occurrence of nearby or contiguous wetland habitats.

\section{2-7a. Possibility of Hydrophytic Recolonization}

\begin{tabular}{cl}
\hline Scale & \multicolumn{1}{c}{ Factor } \\
\hline 5 & Presence of hydrophytic vegetation on-site and on adjacent sites \\
3 & Presence of hydrophytic vegetation adjacent to site \\
0 & Absence of wetland vegetation in all settings \\
\hline
\end{tabular}

2-7b. Possibility of Wildlife Recolonization

\begin{tabular}{cl}
\hline Scale & \\
\hline 5 & Presence of wetlands within $50 \mathrm{~m}$ of site \\
3 & Presence of wetlands within $100 \mathrm{~m}$ of site \\
1 & Presence of wetlands within $200 \mathrm{~m}$ of site \\
0 & No wetlands adjacent to site \\
\hline
\end{tabular}

\section{ENGINEERING DESIGN AND CONSTRUCTION FACTORS}

\section{2-8. Size of Site}

The size for a mitigatiOnsite is dependent on the mitigation area requirements the $\mathrm{DOH}$ must meet and the features of the site selected for a mitigation project. In some cases, a mitigation project represents a joint or pooled effort, combining the mitigation requirements for two or more small projects into one mitigatiOnsite.

Steep topographic relief often limits the potential size of naturally occurring wetlands in most regions of West Virginia. As a result, natural wetlands are frequently small, less than 20 acres, and restricted to stream and river floodplains. They frequently occur in isolated locations. The same conditions limit the size and location of potential mitigation wetland sites.

Establishing criteria for calculating the size of mitigation wetlands, therefore, is a function of project requirements and the physical limitations of potential mitigatiOnsites. The assumption for establishing relevance for optimum size is based on project size requirements that are dictated by the Section 404 regulatory process and the potential for a prospective site to accommodate the minimum mitigation size requirement. 


\begin{tabular}{|c|c|}
\hline Scale & Factor \\
\hline 5 & $\begin{array}{l}\text { Potential for site development in excess of two times the minimum size } \\
\text { requirement }\end{array}$ \\
\hline 3 & $\begin{array}{l}\text { Potential for site development of up to two times the minimum size } \\
\text { requirement }\end{array}$ \\
\hline 1 & Sufficient—meets minimum size requirement \\
\hline 0 & Inadequate - does not meet minimum size requirement \\
\hline
\end{tabular}

\section{2-9. Potential for Expansion Combined with Design Flexibility}

This criterion refers to site contiguity and the potential for expansion within an established drainage system. A single mitigatiOnsite where there can be design flexibility, potential for expansion, and integration into existing contiguous wetland habitats is the preferred setting. Furthermore, existing wetlands within a project area can be used as representative examples of expected results.

\begin{tabular}{cl}
\hline Scale & \multicolumn{1}{c}{ Factor } \\
\hline 5 & $\begin{array}{l}\text { Excellent flexible design capacity to support future expansion with contiguous } \\
\text { functional wetland habitats within drainage basin }\end{array}$ \\
3 & $\begin{array}{l}\text { Some flexible design capacity to support future expansion with contiguous } \\
\text { functional wetland habitats within drainage basin }\end{array}$ \\
0 & $\begin{array}{l}\text { No flexible design capacity to support future expansion with contiguous } \\
\text { functional wetland habitats within drainage basin }\end{array}$ \\
\hline
\end{tabular}

\section{2-10. Excavation}

Refers to a qualitative rating based on assumptions made during field observation, USGS 7.5' topographic quadrangle maps, and soils data. Excavations would be required to construct suitable elevations, contours, and grades to provide sufficient hydrological input to allow the development of constructed wetlands. Extensive excavation may become too costly and may create excessive secondary impacts.

\begin{tabular}{cll}
\hline Scale & & Factor \\
\hline 5 & No excavation required & \\
4 & $<3$ feet on average & \\
3 & 3 to 6 feet on average & \\
2 & 6 to 10 feet on average & \\
1 & 10 to 15 feet on average & \\
0 & $>15$ feet on average & \\
\hline
\end{tabular}

\section{2-11. Topography}

Refers to general categories defined by NRCS terminology. This rating is based on field reviews and USGS 7.5' topographic quadrangle maps. In general, the flatter the 
topography, the more suitable for wetland creation.

\begin{tabular}{cll}
\hline Scale & & Factor \\
\hline 5 & Flat & \\
4 & Gently rolling & \\
3 & Moderately rolling & \\
2 & Rolling & \\
1 & Steep & \\
0 & Very steep & \\
\hline
\end{tabular}

\section{2-12. Construction Access}

Refers to the physical site conditions and their suitability in providing construction and maintenance access to the mitigatiOnsite. Sites easily accessible by construction equipment are preferred.

\begin{tabular}{cl}
\hline Scale & \multicolumn{1}{c}{ Factor } \\
\hline 5 & Completely accessible by all equipment \\
4 & Completely accessible by minor equipment \\
3 & Partially accessible by all equipment \\
2 & Partially accessible by minor equipment \\
1 & Access can only be accomplished through major construction \\
0 & Inaccessible \\
\hline
\end{tabular}

\section{2-13. Constructibility}

Refers to a qualitative assessment of the waste material management, existing soil conditions, construction phasing opportunities, the shape and size of the site, practicality of construction, temporary construction impacts, construction techniques and methodology options, materials, and hauling distances. Sites with a high construction potential are preferred.

\begin{tabular}{cl}
\hline Scale & \multicolumn{1}{c}{ Factor } \\
\hline 5 & High potential \\
4 & Some minor problems with construction \\
3 & Constructible with extensive planning \\
2 & Less constructible, greater likelihood of construction difficulties \\
1 & Construction difficult, high risk of failure \\
0 & Not feasible or practical \\
\hline
\end{tabular}

\section{2-14. Construction Intrusion into Adjacent Habitats}

Refers to the potential for intrusion or disturbance of existing natural habitat as a result of the construction the mitigatiOnsite. Minimal intrusion is preferred. 


\begin{tabular}{cl}
\hline Scale & \multicolumn{1}{c}{ Factor } \\
\hline 5 & $\begin{array}{l}\text { Low potential for impacts to adjacent areas or impacts are to poor quality } \\
\text { habitats }\end{array}$ \\
3 & $\begin{array}{l}\text { Moderate potential for impacts requiring temporary disturbance and } \\
\text { restoration }\end{array}$ \\
0 & High potential for impacts creating permanent disturbance to off-site areas \\
\hline
\end{tabular}

\section{ANTHROPOGENIC FACTORS}

\section{2-15. Potential Degradation due to External and Internal Factors}

Refers to the potential for human intrusion at the mitigatiOnsite after construction. This evaluation is based on existing offsite and in situ factors, e.g., conflicting land use practices and acid mine drainage (AMD), Generally, mitigation wetlands cannot be used as treatment wetlands, even though they may have the capacity to mediate impaired waters related to surrounding land use practices or AMD. Therefore, evaluating functional attributes for mitigation wetlands is based on overall habitat improvement, not treatment of a specific impairment.

\begin{tabular}{|c|c|}
\hline Scale & Factor \\
\hline 5 & Site without intrusive adjacent land uses and impairing in situ factors \\
\hline 3 & $\begin{array}{l}\text { Site with the potential for intrusive adjacent land uses and/or impairing in situ } \\
\text { factors }\end{array}$ \\
\hline 1 & $\begin{array}{l}\text { Site with some evidence of intrusive adjacent land uses and/or impairing in situ } \\
\text { factors }\end{array}$ \\
\hline 0 & $\begin{array}{l}\text { Site with strong evidence of intrusive adjacent land uses and/or impairing in } \\
\text { situ factors }\end{array}$ \\
\hline
\end{tabular}

\section{2-16. Archaeological Resource Potential}

Refers to potential or verified presence or absence of archaeological resources within or adjacent to the candidate wetland mitigatiOnsites. Sites with a confirmed absence of intact archaeological deposits are rated highest, while those with confirmed presence are rated lowest.

\begin{tabular}{|c|c|}
\hline Scale & Factor \\
\hline 5 & $\begin{array}{l}\text { Confirmed absence of significant archaeological site within or near } \\
\text { mitigatiOnsite }\end{array}$ \\
\hline 4 & Confirmed absence of significant archaeological site within site \\
\hline 3 & Probable absence of a significant archaeological site within mitigatiOnsite \\
\hline 2 & $\begin{array}{l}\text { Probable presence of archaeological site within mitigatiOnsite, significance } \\
\text { unknown }\end{array}$ \\
\hline 1 & Probable presence of a significant archaeological site within mitigatiOnsite \\
\hline 0 & Confirmed presence of significant archaeological site within mitigatiOnsite \\
\hline
\end{tabular}




\section{2-17. Probable Number of Property Owners Affected}

Refers to the apparent number of potentially affected property owners. The number of property owners is based on preliminary examination of property ownership records at county court houses. The number of property owners impacted affects the cost of acquisition, and possibly the ability to maintain the site as a successful project that would be free from potential liability.

\begin{tabular}{cll}
\hline Scale & & Factor \\
\hline 5 & Single property owner & \\
3 & Two property owners & \\
0 & More than two property owners & \\
\hline
\end{tabular}

\section{2-18. Appropriateness of Adjacent Land Use}

Refers to the effect of the mitigation wetland on existing and future development, and on the compatibility of surrounding development with the candidate site. Sites with minimal potential for impact to adjacent property owners are preferred.

\begin{tabular}{cl}
\hline Scale & \multicolumn{1}{c}{ Factor } \\
\hline 5 & Natural landscape with mature or developing forest cover \\
4 & Extensive agricultural land \\
3 & Mixed natural landscape and agricultural land \\
2 & Mixed natural and residential land \\
1 & Mostly residential land \\
0 & Mostly densely developed commercial/industrial land \\
\hline
\end{tabular}

\section{2-19. Prime Farmland}

Refers to the presence or absence of Prime Farmland soils on-site as defined by the NRCS. Prime Farmland soils possess an inherent value in their potential for agricultural production. It is preferable to preserve Prime farmland wherever possible.

\begin{tabular}{cl}
\hline Scale & \\
\hline 5 & Factor \\
3 & Possible presence of Prime Farmland soils \\
0 & Presence of Prime Farmland soils \\
\hline
\end{tabular}

